\title{
WHITE STURGEON MITIGATION AND RESTORATION IN THE COLUMBIA AND SNAKE RIVERS UPSTREAM FROM BONNEVILLE DAM.
}

ANNUAL PROGRESS REPORT

APRIL 2007 - MARCH 2008

\author{
Edited by: \\ Christine Mallette \\ Oregon Department of Fish and Wildlife
}

In Cooperation With:

Columbia River Inter-Tribal Fish Commission

Montana State University

Washington Department of Fish and Wildlife

Prepared For:

U.S. Department of Energy

Bonneville Power Administration

Environment, Fish and Wildlife

Portland, Oregon, USA

Project Number 1986-050-00

Contract Number 39233

April 2009 


\section{TABLE OF CONTENTS}

Page

\section{EXECUTIVE SUMMARY}

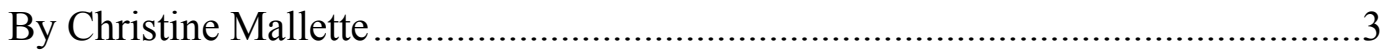

REPORT A. Evaluate the success of developing and implementing a management plan for enhancing production of white sturgeon in reservoirs between Bonneville and McNary dams. An update of abundance, life history parameters, and population dynamics of white sturgeon in John Day Reservoir, and a summary of annual recruitment of age- 0 white sturgeon in four Columbia River reservoirs.

By Adam J. Storch, Colin G. Chapman and Tucker A. Jones

REPORT B. Evaluate the success of developing and implementing a management plan to enhance production of white sturgeon in reservoirs between Bonneville and McNary dams Progress on implementing the fisheries management component of the white sturgeon management plan for the Columbia River between Bonneville and McNary dams including results of surveying 2007 sport and commercial white sturgeon fisheries.

By Olaf P. Langness, Dennis R. Gilliland, Brad J. Cady and

Brad James

REPORT C. Developing, implementing, and evaluating a management plan for enhancing production of white sturgeon in reservoirs between Bonneville and McNary dams. The results of efforts to capture and mark white sturgeon in John Day Reservoir for population abundance estimates.

By Blaine Parker

REPORT D. Determine spawning interval of white sturgeon in the Columbia River Progress update on the maturation cycle in wild white sturgeon

By Molly A. H. Webb and Kevin M. Kappenman 


\section{EXECUTIVE SUMMARY}

We report on our progress from April 2007 through March 2008 on determining the effects of mitigative measures on productivity of white sturgeon populations in the Columbia River downstream from McNary Dam, and on determining the status and habitat requirements of white sturgeon populations in the Columbia and Snake rivers upstream from McNary Dam. The study is a cooperative effort by the Oregon Department of Fish and Wildlife (ODFW; Report A), Washington Department of Fish and Wildlife (WDFW; Report B), Columbia River Inter-Tribal Fish Commission (CRITFC; Report C), and Montana State University (MSU; Report D).

This is a multi-year study with many objectives requiring more than one year to complete; therefore, findings from a given year may be part of more significant findings yet to be reported. Highlights of results of our work are:

\section{Report A}

- The total population of white sturgeon ( $\geq 54 \mathrm{~cm} \mathrm{FL)} \mathrm{in} \mathrm{John} \mathrm{Day} \mathrm{Reservoir} \mathrm{in} 2007$ was estimated at 42,622 fish. The previous estimate completed in 2004 was 43,500 fish.

- The 2007 stock assessment indicated a $2 \%$ decrease $(n=905)$ in sub-legal sized fish $(54-$ $109 \mathrm{~cm} \mathrm{FL})$, a $45 \%$ increase $(\mathrm{n}=493)$ in sport-legal sized fish $(110-137 \mathrm{~cm} \mathrm{FL})$, and a $201 \%$ increase $(\mathrm{n}=985)$ in over-legal sized fish $(\geq 138 \mathrm{~cm} \mathrm{FL})$ from 2004 levels.

- The 2007 size distribution of white sturgeon in John Day Reservoir was estimated to be: 93\% $<110 \mathrm{~cm} \mathrm{FL}, 4 \% 110-137 \mathrm{~cm} \mathrm{FL}$, and 3\%>137 cm FL.

- The overall recapture rate of PIT-tagged sturgeon was $7.9 \%$.

- Catch per effort for all reservoir sections and weeks combined was 3.81 white sturgeon per setline-day.

- Catch was distributed throughout the reservoir however, there was a significant difference in mean CPUE between reservoir sections (ANOVA, $\mathrm{F}=5.8, \mathrm{P}=0.01$ ). Mean CPUE was highest in sections 7 and 8 (6.9 and 8.0 respectively), and lowest in sections 1 and $2(0.67$ and 0.65 respectively).

- $\quad$ Of the 688 white sturgeon that were marked and recaptured during sampling periods 1-3, 338 $(49 \%)$ were recovered within $\pm 5 \mathrm{rkm}$ of the original marking location. The average movement of recaptured fish was $5.1 \mathrm{~km}$ upstream from where they were marked originally. The furthest upstream movement observed was $77 \mathrm{rkm}$, and the furthest downstream movement observed was $69 \mathrm{rkm}$.

- The median relative weight of fish captured in 2007 was 101, similar to the 2004 John Day Reservoir stock assessment.

- We estimated ages for 104 white sturgeon captured from John Day Reservoir during the 2007 stock assessment. Age estimates ranged from 7-61 years, with a median age of 20 years.

- Annual growth increments (AGI) for white sturgeon from John Day Reservoir were estimated from 1) the 2004 and 2007 von Bertalanffy growth functions, and 2) from PIT 
tagged sturgeon recaptured during 1987-2007. Predicted AGIs estimated from the 2004 and 2007 von Bertalanffy growth functions decreased as fish size increased, ranging from approximately $6.5 \mathrm{~cm} /$ year for white sturgeon 41-60 cm FL, to approximately $0.5 \mathrm{~cm} /$ year for fish greater that $180 \mathrm{~cm}$ FL. AGIs estimated from recaptured fish showed varied growth rates throughout all sizes with an increasing trend until approximately $121-140 \mathrm{~cm}$. Growth for white sturgeon 41-100 cm FL averaged $4.09 \mathrm{~cm} /$ year, increasing to $7.63 \mathrm{~cm} /$ year for fish 121-160 cm FL, then decreasing to $5.53 \mathrm{~cm} /$ year for white sturgeon over $181 \mathrm{~cm}$ FL.

- In 2007, age-0 white sturgeon were captured in McNary $(n=2)$, The Dalles $(n=9)$, and Bonneville $(\mathrm{n}=21)$ reservoirs; no age- 0 white sturgeon were captured John Day Reservoir.

\section{Report B}

- The 2007 white sturgeon harvest (recreational, commercial, and subsistence) in Management Zone 6 was 2,324 fish. This represents a 15 percent increase over the previous year, which in turn was the lowest total harvest since 1991. The harvest level is reflective of the continued guideline reductions (2002-2006) in all three pools. Recreational retention seasons were closed on 30 July in Bonneville Reservoir, 29 March in The Dalles Reservoir, and 11 June in John Day Reservoir.

- Compliance with the Sturgeon Management Task Force (SMTF) annual harvest guidelines was addressed through in-season management actions. Harvest in Bonneville Reservoir during the past five seasons (2003-2007) has averaged $100 \%$ of the recreational guideline and $79 \%$ of the commercial guideline. Harvest in The Dalles Reservoir for the same period averaged $108 \%$ of the recreational guideline and $94 \%$ of the commercial guideline. Harvest in John Day Reservoir averaged $113 \%$ of the recreational guideline and $87 \%$ of the commercial guideline.

- Recreational effort in Bonneville Reservoir decreased 12\% for white sturgeon. Boat Harvest Per Unit of Effort (HPUE) was the lowest on record in 2007. Bank HPUE more than doubled from 2006, but still is the third lowest on record. In The Dalles Reservoir, angler trips for white sturgeon during the 2007 retention period decreased $30 \%$ from the 2006 retention period effort, but increased by $15 \%$ in John Day Reservoir. Combined boat and bank HPUE in John Day Reservoir was the second highest on record, nearly matching the high in 1997 and the highest boat anglers' HPUE for fish with a fork length of $110-137 \mathrm{~cm}$ (approximately equivalent to 48-60 in total length) since 1997.

- The percentage of oversize fish handling in the estimated white sturgeon sport catch has increased in all three reservoirs compared to 2006. The sturgeon-targeted angler trips during the months of June and July account for $90 \%$ of the total 2007 oversize catch and release. The percentage of oversize white sturgeon handled in the John Day Reservoir recreational fishery is the lowest among the three reservoirs below McNary dam. 


\section{Report C}

- From December 4, 2006 to January 10, 2007 Tribal fishers set 804 overnight gillnet sets. This effort captured a total of 4,401 white sturgeon (including recaptures). Tribal fishers measured 4,236 white sturgeon and marked 3,607 of them by removing the twelfth left lateral scute. A total of 2,485 fish also received a PIT tag.

- White sturgeon captured in these efforts were 32 to $226 \mathrm{~cm}$ in fork length, with a mean of $86.0 \pm 0.20 \mathrm{~cm}$, the shortest mean fork length for the last three John Day evaluation periods (2004, 2001 and 1996).

- Catch per net was 5.44 fish and more than twice as high than observed in 2004 (2.02), the previous John Day sampling year.

- About $96 \%$ of the white sturgeon caught were smaller than 48 inches TL (minimum legal size).

- We observed similar proportions of sub-legals ( $<43$ inches FL), legal sized (43-54 inches FL) and over-legal sized fish ( $>54$ inches FL) from 2001 to 2004. Proportions of sub-legals, legals, and over-legals in 2001 were $93.7 \%, 4.7 \%$, and $1.6 \%$ respectively, and in 2004 the proportions were $96.6 \%, 2.1 \%$, and $1.4 \%$ respectively.

\section{Report D}

- Montana State University researchers performed gonadal biopsies on adult white sturgeon captured with set-lines below Bonneville Dam. Gonad samples were processed histologically.

- Since 2000, a total of 660 adult white sturgeon have been marked with a combination of spaghetti tags, scute marks, and PIT tags below Bonneville Dam.

- In 2007, a total of 121 fish were caught, 50 of which were tagged in previous years and 58 of which were new to the study. The remaining 13 fish were in-season re-captures.

- A total of 90 gonad samples were collected for histological analysis. Of these, 56 were collected from females, 34 were collected from males.

- The reproductive structure of the oversize white sturgeon population below Bonneville Dam was determined using the 2000-2007 data. Of the females sampled, 58\% were previtellogenic (Stages 1 and 2), 28\% were vitellogenic (Stages 3 and 4), 3\% were postvitellogenic or ripe (Stage 5), 7\% were postovulatory (Stage 7), and 4\% were undergoing follicular atresia (Stage 8). Of the males sampled, 59\% were non-reproductive (Stage 2), 16\% were mid-spermatogenic (Stage 3 and 4), 18\% were spermiating (Stage 5), and 7\% were post-spermiation (Stage 6). 


\title{
WHITE STURGEON MITIGATION AND RESTORATION IN THE COLUMBIA AND SNAKE RIVERS UPSTREAM FROM BONNEVILLE DAM
}

\author{
ANNUAL PROGRESS REPORT
}

APRIL 2007 - MARCH 2008

\section{REPORT A}

Evaluate the success of developing and implementing a management plan for enhancing production of white sturgeon in reservoirs between Bonneville and McNary dams

This report includes: 1) An update of abundance, life history parameters, and population dynamics of white sturgeon in John Day Reservoir, and 2) a summary of annual recruitment of age- 0 white sturgeon in four Columbia River reservoirs.

\author{
Prepared By: \\ Adam J. Storch \\ Colin G. Chapman \\ and \\ Tucker A. Jones
}

Oregon Department of Fish and Wildlife

Clackamas, Oregon, USA

November 2008 


\section{TABLE OF CONTENTS}

ABSTRACT




\begin{abstract}
This report summarizes data collected from 1 April 2007 through 31 March 2008 and provides: 1) an update of abundance, life history parameters, and population dynamics for white sturgeon Acipenser transmontanus in John Day Reservoir, and 2) an evaluation of annual recruitment of age- 0 white sturgeon in four Columbia River reservoirs.

Sampling to estimate the abundance of white sturgeon in John Day Reservoir was coordinated with staff from the Oregon Department of Fish and Wildlife (ODFW), the Columbia River Inter-Tribal Fish Commission (CRITFC), and the Washington Department of Fish and Wildlife (WDFW). From 4 December 2006 through 10 January 2007 CRITFC staff contracted with tribal commercial fishers who set 804 nets and captured 4,236 white sturgeon. From 11 June through 23 August 2007 staff from ODFW and WDFW set 583 setlines and captured 2,221 white sturgeon. Combined effort during both winter and summer sampling resulted in the capture of 6,457 white sturgeon, of which 4,536 (70\%) received passive integrated transponder (PIT) tags. A total of 523 PIT-tagged white sturgeon were recaptured during the summer sampling periods; 189 were from this year's marking efforts and 339 were marked in previous years. The recapture rate of all marked fish was 7.9\%. The recapture rate of fish marked in 2006/2007 was $2.9 \%$. During summer sampling, white sturgeon were captured throughout John Day Reservoir; catch rates averaged 222 fish per section. Between marking and subsequent recapture, white sturgeon in John Day Reservoir moved an average of 5.1 river kilometers (rkm) upstream. Using multiple mark-recapture estimates, the total population of white sturgeon $\geq 54$ cm (24 inches) fork length (FL) in John Day Reservoir in 2007 was estimated at 42,622 fish. The size distribution of the population was estimated to be $6 \% 54-69 \mathrm{~cm} \mathrm{FL,} \mathrm{87 \%} 70-109 \mathrm{~cm}$ FL, 4\% 110-137 cm FL, 1\% 138-166 cm FL, and 2\% $\geq 166 \mathrm{~cm}$ FL.

We assessed recruitment of age-0 white sturgeon in Bonneville, The Dalles, John Day, and McNary reservoirs in 2007. Sampling gear consisted of small mesh gill nets fished at standard locations within each reservoir. We set 151 nets and captured 389 white sturgeon, of which $32(8 \%)$ were classified as age-0. Age- 0 white sturgeon were caught in all reservoirs except John Day. We applied PIT tags to a total of 327 white sturgeon ( $84 \%$ of total catch) captured during the 2007 age- 0 recruitment index.
\end{abstract}




\section{INTRODUCTION}

White sturgeon Acipenser transmontanus is the largest species of North American sturgeon and is found from southern California to the Gulf of Alaska (Scott and Crossman 1973). White sturgeon inhabit approximately 1600 kilometers of the main stem Columbia River from the estuary to Idaho and Canada. Overfishing during the late 1800s resulted in substantial population declines, warranting the cessation of all white and green sturgeon harvest (Craig and Hacker 1940). By the 1950s, white sturgeon numbers had improved enough to once again support limited commercial and recreational fisheries. With continuing declines in anadromous salmonid abundance, there has been increased participation in the white sturgeon fishery. Total harvest of sturgeon doubled in the 1970s and again in the 1980s (Tracy 1993). Since 1986, ODFW and other tribal, state and federal agencies have worked to monitor sturgeon populations, determine the cause of their declines, and take actions that will maintain a balance between conservation and productive white sturgeon fisheries. Over time, project goals have changed as new information has clarified potential restoration actions.

The primary goal of the current project is to implement and evaluate measures previously identified to protect and enhance white sturgeon populations and to mitigate for effects of the Federal Columbia River Power System (FCRPS) on production of white sturgeon in Columbia River impoundments between Bonneville Dam and the mouth of the Snake River.

To ensure that white sturgeon populations remain productive, we have developed protocols to monitor white sturgeon abundance and recruitment throughout the lower Columbia River basin. We conduct annual assessments of white sturgeon abundance and population dynamics in the reservoirs between Bonneville Dam and McNary Dam on the Columbia River, known collectively as Zone 6. Data collected during these surveys allow us to update abundance and population characteristics of white sturgeon, and assess management and mitigation approaches on a three year basis. We conduct annual age-0 indexing to evaluate the relative success of white sturgeon spawning. By sampling for young-of-year (age-0) white sturgeon at specific index sites in four Columbia River reservoirs, we can describe distribution and relative density of age- 0 white sturgeon in each reservoir. This information is then used to identify recruitment trends among years and among reservoirs.

This report summarizes work performed from 1 April 2007 through 31 March 2008 for the Bonneville Power Administration Project 198605000. During this period, we participated in two distinct efforts to assess populations of white sturgeon in the Columbia River upstream from Bonneville Dam:

1) From June through August 2007 we collected data to assess abundance and population characteristics of white sturgeon in John Day Reservoir.

2) During October 2007 we collected data to assess annual recruitment of age-0 white sturgeon in Bonneville, The Dalles, John Day, and McNary reservoirs in the Columbia River.

Since 2001, stock assessment surveys have been conducted every year, rotating between the three reservoirs in Zone 6; prior to 2001, stock assessment surveys were conducted on a fiveyear rotation. Since its inception in 1997, age-0 indexing has been conducted on an annual basis. 


\section{METHODS}

\section{Stock Assessment}

Sampling for white sturgeon in John Day Reservoir was divided into three periods (periods 1-3). During period 1, gill nets were used to capture white sturgeon; during periods 2-3, we used baited set lines.

Sampling during period 1 took place from 4 December 2006 through 10 January 2007. During this time, CRITFC staff, working with tribal commercial fishers, used gill nets distributed throughout the reservoir to capture white sturgeon (see Report $\mathrm{C}$ for details regarding tribal gill net methodology).

Sampling during periods 2 and 3 took place from 11 June through 23 August 2007, and was conducted jointly by ODFW and WDFW. Period 2 was from 11 June to 18 July, and period 3 from 23 July to 22 August. John Day Reservoir was divided into ten sections, excluding boat

restricted zones. Sections ranged between 7 and $9 \mathrm{~km}$ in length (Figure A-1). Sampling effort was distributed equally throughout the reservoir, and all reservoir sections were sampled during each period.

During periods 2 and 3, setlines were used to capture white sturgeon (see Elliot and Beamesderfer 1990). Setlines measured $183 \mathrm{~m}$ in length and were equipped with 12/0, 14/0, and 16/0 barbed circle hooks. Each setline contained 13 hooks of two sizes and 14 hooks of the remaining size (selected randomly for each line), for a total of 40 hooks per line. All hooks were baited with pickled squid (Loligo spp.), which has been shown to yield higher catch rates than other baits (North et al., 1998). Setlines were set on Mondays and checked and reset on Tuesdays and Wednesdays. All gear was checked and pulled on Thursdays. Hooks were rebaited with fresh squid when necessary or every 48 hours.

All white sturgeon were measured to the nearest $1.0 \mathrm{~cm} \mathrm{FL}$ and examined for external tags, lost tag scars, pectoral fin scars (from previous aging samples), and scute removal scars. Weights (nearest $1.0 \mathrm{~kg}$ ) and structures for use in aging were collected from a sub-sample of up to 30 fish per $20 \mathrm{~cm}$ length interval. All recaptured fish were also weighed. White sturgeon that did not already have one, were tagged with a 134.2 MHz ISO PIT tag and externally marked by removing the second left lateral scute to identify individuals as having PIT tags. 


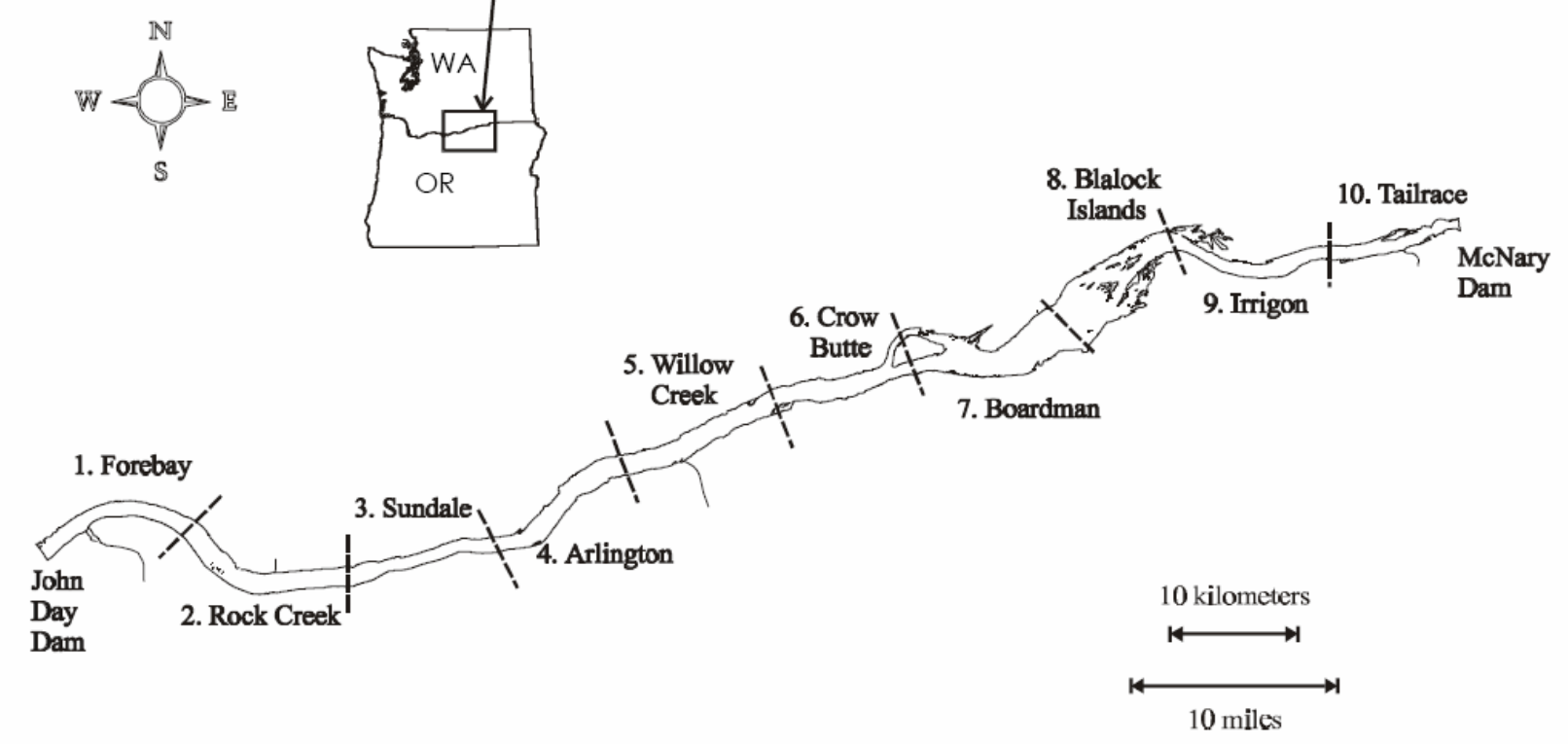

Figure A-1. Stock assessment sampling sections and sampling sites, John Day Reservoir, 2007.

Ages of captured white sturgeon were estimated from thin cross-sections of pectoral fin spines following procedures outlined in Beamesderfer et al. (1989). Up to 30 fish from each 20 $\mathrm{cm}$ length interval were aged. Fin-spine sections were aged two times by each of two experienced readers, with one of the readers being assigned the role of primary reader. When an age assigned to an individual fish was not consistent between readers, the primary reader assigned a final age to the fish.

The relationship between white sturgeon fork length (L) and age (x) in John Day reservoir was described by the von Bertalanffy growth function:

$$
L_{x}=L_{\infty}\left[1-e^{-k\left(x-t_{0}\right)}\right]
$$

where, $\mathrm{L}_{\infty}=$ length at infinity, $\mathrm{k}=$ growth coefficient, and $\mathrm{t}_{0}=$ age at length zero (von Bertalanffy, L. 1938). Parameters for the von Bertalanffy growth function were derived from the length and age data using nonlinear regression (SAS Institute 2003).

The relationship between fork length (L) and weight (W) was described by the exponential function, $W_{L}=\exp \left[a^{*} \ln (L)-b\right]$. Parameters for the length-weight function were derived using nonlinear regression (SigmaStat 3.5, Systat Software, Inc.). The condition of white sturgeon $\geq 70 \mathrm{~cm}$ FL was assessed using estimates of relative weight $\left(\mathrm{W}_{\mathrm{r}}\right)$ based on the standard weight equation from Beamesderfer (1993), $W_{s}=2.735 E-6 * L^{3.232}$. Analysis-ofvariance (ANOVA) and a Tukey's pairwise comparison (SigmaStat 3.5, Systat Software, Inc.) were used to test for significant differences in relative weights of fish between among the 2007 sampling periods.

Annual growth increments (AGI) for white sturgeon in John Day Reservoir were calculated from: 1) the 2004 and 2007 von Bertalanffy growth functions, and 2) data from all marked and recaptured sturgeon in John Day Reservoir that were at large for at least six months 
between capture events. Annual growth increments derived using each method were compared to examine differences between predicted and observed growth.

Overall population abundance $(N)$ of white sturgeon in John Day Reservoir was estimated using a Schnabel population estimator (Schnabel 1938), adjusted by Chapman (1952, 1954), based on the number of PIT-tags applied and recaptured. The Schnabel estimate was calculated as:

$$
N=\frac{\sum_{t=1}^{m} C_{t} M_{t}}{R+1}
$$

where $m=$ the number of sampling periods, $M_{t}=$ total number of marked fish at the start of the $t^{\text {th }}$ sampling period $(t=1, \ldots, m), C_{t}=$ total samples taken in period $t, R_{t}=$ number of recaptures in the sample $C_{t}$, and $R=$ total recaptures during the experiment (sum of $R_{t}$ ) (Ricker 1975). Although not noted in the above equation, the total number of marked fish at the start of a given period was adjusted to account for removals. Removals included mortalities during sampling and estimated harvest from sport and commercial fisheries.

The Schnabel estimator was used to estimate the overall abundance of sturgeon in the 70$109 \mathrm{~cm}$ FL size class (the mark group with the largest sample sizes). The length-frequency distribution of the setline catch was used to apportion the Schnabel population estimate by one $\mathrm{cm}$ increments within the $70-109 \mathrm{~cm}$ FL size class. The Schnabel estimate was then expanded to estimate abundance of the remaining size groups ( $<70 \mathrm{~cm} \mathrm{FL}$ and $\geq 110 \mathrm{~cm} \mathrm{FL}$ ) based on the relative frequency of these size classes in the total 2007 setline catch and after adjusting for sizespecific differences in gear vulnerability (Beamesderfer et al., 1995). This method precludes the estimation of $95 \%$ confidence intervals (CIs) for these groups.

\section{Age-0 Indexing}

During October 2007, staff from ODFW, WDFW, and CRITFC conducted sampling in Bonneville, The Dalles, John Day, and McNary reservoirs to evaluate annual recruitment of age0 white sturgeon (Figure A-2). Sampling took place in McNary Reservoir from 8 October to 11 October, John Day Reservoir from 15 October to 19 October, The Dalles Reservoir from 22 October to 25 October, and in Bonneville Reservoir from 29 October to 1 November.

Gill nets were used to sample for age- 0 white sturgeon. A single gill net was deployed at predetermined, standard sites within each reservoir. Sampling methodology and locations were consistent with past years, and involved fishing nets overnight at the same sites throughout each week. Gill nets measured $91.4 \mathrm{~m}$ in length and $3.7 \mathrm{~m}$ in height and were constructed with $5.1 \mathrm{~cm}$ stretched-measure multifilament nylon mesh. Nets were fished overnight on the river bottom for approximately 24 hours. Because nets were deployed during daylight hours and most catch of white sturgeon is believed to occur during darkness (McCabe and Tracy 1994), all nets were considered to have been sampling for equal amounts of "effective fishing time". Therefore, each overnight set was treated as a single unit of effort; catch per hour was not calculated. 
All fish captured in the gill nets were removed and placed in a livewell filled with river water at ambient conditions until they could be examined (with the exception of live salmon, which were released immediately to reduce possible stress or injury from handling). All bycatch was identified to species, with the exception of sculpin Cottus spp., crayfish Pacifastacus spp. and crappie Pomoxis spp., which were identified to genus. Any salmon that had expired in the net was examined for marks, measured to the nearest $1 \mathrm{~mm}$, and returned to the river.

All white sturgeon were measured to the nearest $1 \mathrm{~mm}$ FL and examined for external tags, lost tag scars, pectoral fin scars (from previous aging samples), and scute removal scars. Weights (to the nearest 0.1 or $0.001 \mathrm{~kg}$, depending on size) and structures for use in aging were collected from a sub-sample of up to 30 fish per $20 \mathrm{~cm}$ length interval. White sturgeon $\geq 35 \mathrm{~cm}$ FL that did not already have one, were tagged with a $134.2 \mathrm{MHz}$ ISO PIT tag and externally marked by removing the second left lateral scute to identify individuals as having a PIT tag. Based on a length-at-age analysis of fish which provided aging structures, all sturgeon $\leq 30 \mathrm{~cm}$ FL were considered to be age- 0 .

For white sturgeon, both the proportion of positive efforts $\left(E_{p}\right.$; proportion of all sets that captured at least one sturgeon) and the catch-per-unit-effort (CPUE; number of white sturgeon caught per overnight set) were calculated. For small numbers of fish, the estimate of $E_{p}$ may provide a better measure of relative density than CPUE (Counihan et al., 1999). Both the proportion of positive efforts and CPUE were estimated for age- 0 white sturgeon, and for all white sturgeon captured.

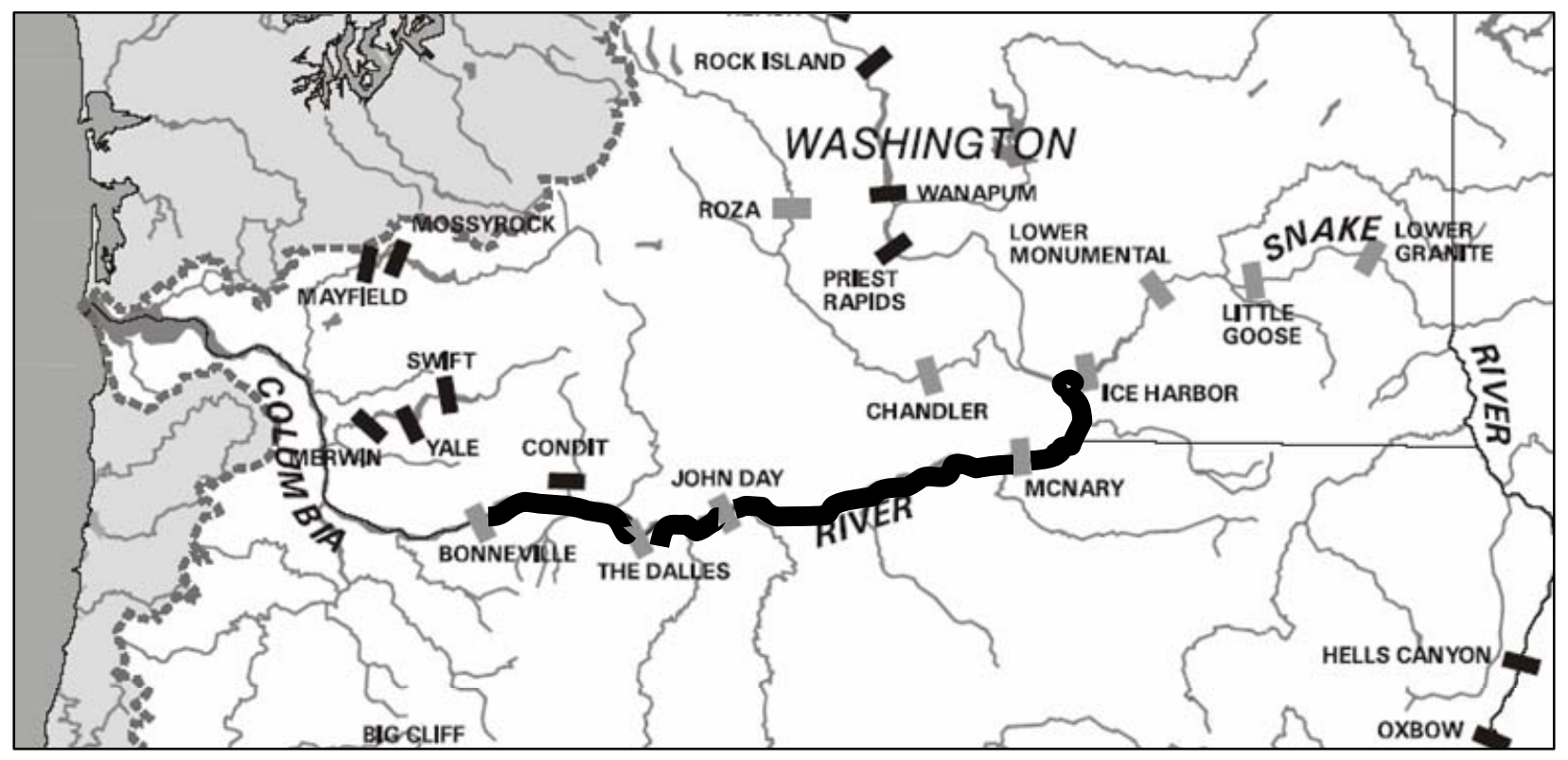

Figure A-2. Map of age-0 sampling locations in the Columbia River. Highlighted river sections indicate the reservoirs in which age-0 sampling took place during October and November of 2007. 


\section{RESULTS}

\section{Stock Assessment}

\section{Effort and Catch}

During period 1, tribal commercial fishers set 804 gill nets in John Day Reservoir and caught 4,236 white sturgeon. Of the 4,236 white sturgeon captured, 2,845 (67\%) received PIT tags. During periods 2-3, staff from ODFW and WDFW set 583 setlines in John Day Reservoir and caught 2,221 white sturgeon (Tables A-1 and A-2). We placed PIT tags in 1,691 (76\%) white sturgeon, and $523(24 \%)$ had a PIT tag at capture. Of the 523 recaptures, $189(36 \%)$ were marked during the 2006/2007 field season. The overall recapture rate of white sturgeon PIT tagged during 2006/2007 was $2.9 \%$.

White sturgeon were captured in all reservoir sections during all sampling periods. For all sections and weeks combined (periods 2-3), CPUE was 3.81 white sturgeon per setline (Table A-3). There was no significant difference in mean CPUE between sampling periods ( $\mathrm{t}$-test, $\mathrm{t}=$ $0.61, \mathrm{df}=8, \mathrm{P}=0.56)$. There was, however, a significant difference in mean CPUE between sampling sections (ANOVA, $\mathrm{F}=5.8, \mathrm{df}=9, \mathrm{P}<0.01$ ). Mean CPUE was highest in sections 7 and 8 (6.9 and 8.0 respectively), and lowest in sections 1 and 2 (0.67 and 0.65 respectively).

White sturgeon in John Day Reservoir exhibited limited movement between mark and recapture events during the 2007 stock assessment. Of the 688 white sturgeon that were marked and recaptured during sampling periods 1-3, 338 (49\%) were recovered within $\pm 5 \mathrm{rkm}$ of the original marking location (Table A-4). The average movement of recaptured fish was $5.1 \mathrm{~km}$ upstream from where they were marked originally. The furthest upstream movement observed was $77 \mathrm{rkm}$, and the furthest downstream movement observed was $69 \mathrm{rkm}$.

Table A-1. Sampling effort (number of setline sets) for white sturgeon in John Day Reservoir by week and sampling section, 11 June through 23 August 2007.

\begin{tabular}{|c|c|c|c|c|c|c|c|c|c|c|c|c|}
\hline & \multirow[b]{2}{*}{ Week } & \multicolumn{10}{|c|}{ Sampling Section } & \multirow[b]{2}{*}{ Tota } \\
\hline & & 1 & 2 & 3 & 4 & 5 & 6 & 7 & 8 & 9 & 10 & \\
\hline \multirow{5}{*}{ Period 2} & 24 & & & & & & & & & 27 & 30 & 57 \\
\hline & 25 & 33 & 30 & & & & & & & & & 63 \\
\hline & 26 & & & 26 & 24 & & & & & & & 50 \\
\hline & 28 & & & & & 30 & 28 & & & & & 58 \\
\hline & 29 & & & & & & & 30 & 30 & & & 60 \\
\hline \multirow{5}{*}{ Period 3} & 30 & & & & & & & & & 32 & 26 & 58 \\
\hline & 31 & 36 & 29 & & & & & & & & & 65 \\
\hline & 32 & & & 18 & 26 & & & & & & & 44 \\
\hline & 33 & & & & & 32 & 34 & & & & & 66 \\
\hline & 34 & & & & & & & 32 & 30 & & & 62 \\
\hline All & & 69 & 59 & 44 & 50 & 62 & 62 & 62 & 57 & 62 & 56 & 583 \\
\hline
\end{tabular}


Table A-2. Catches of white sturgeon with setlines in John Day Reservoir by calendar week and sampling section, 11 June through 23 August 2007.

Sampling Section

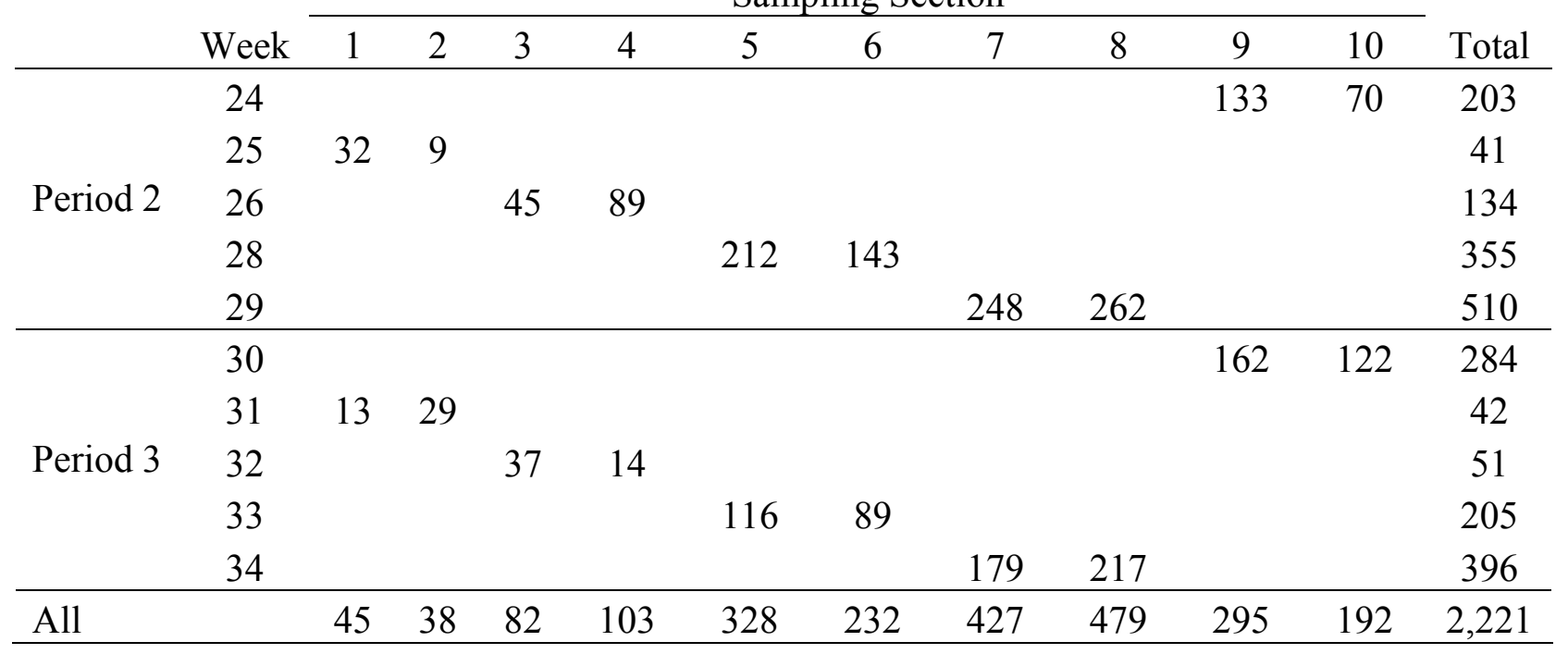

Table A-3. Catch per unit effort of white sturgeon with setlines in John Day Reservoir by week and sampling section, 11 June through 23 August 2007.

Sampling Section

\begin{tabular}{|c|c|c|c|c|c|c|c|c|c|c|c|c|}
\hline & Week & 1 & 2 & 3 & 4 & 5 & 6 & 7 & 8 & 9 & 10 & Total \\
\hline \multirow{5}{*}{ Period 2} & 24 & & & & & & & & & 4.93 & 2.33 & 3.56 \\
\hline & 25 & 0.97 & 0.30 & & & & & & & & & 0.65 \\
\hline & 26 & & & 1.73 & 3.71 & & & & & & & 2.68 \\
\hline & 28 & & & & & 7.07 & 5.11 & & & & & 6.12 \\
\hline & 29 & & & & & & & 8.27 & 8.73 & & & 8.50 \\
\hline \multirow{5}{*}{ Period 3} & 30 & & & & & & & & & 5.06 & 4.69 & 4.90 \\
\hline & 31 & 0.36 & 1.00 & & & & & & & & & 0.65 \\
\hline & 32 & & & 2.06 & 0.54 & & & & & & & 1.16 \\
\hline & 33 & & & & & 3.63 & 2.62 & & & & & 3.11 \\
\hline & 34 & & & & & & & 5.59 & 7.23 & & & 6.39 \\
\hline All & & 0.65 & 0.64 & 1.86 & 2.06 & 5.29 & 3.74 & 6.89 & 8.40 & 4.76 & 3.43 & 3.81 \\
\hline
\end{tabular}


Table A-4. Frequency of movement of fish between marking and recapture events during sampling periods 1-3. Negative numbers indicate the recapture event was downstream of the marking event. Multiple recaptures of individual fish are included.

\begin{tabular}{|c|c|c|}
\hline Number of River KM Moved & Frequency of Recaptures & \% Frequency of Recaptures \\
\hline-70 & 2 & $0.29 \%$ \\
\hline-65 & 1 & $0.15 \%$ \\
\hline-60 & 1 & $0.15 \%$ \\
\hline-55 & 3 & $0.44 \%$ \\
\hline-50 & 3 & $0.44 \%$ \\
\hline-45 & 1 & $0.15 \%$ \\
\hline-40 & 3 & $0.44 \%$ \\
\hline-35 & 10 & $1.45 \%$ \\
\hline-30 & 5 & $0.73 \%$ \\
\hline-25 & 15 & $2.18 \%$ \\
\hline-20 & 10 & $1.45 \%$ \\
\hline-15 & 14 & $2.03 \%$ \\
\hline-10 & 20 & $2.91 \%$ \\
\hline-5 & 171 & $24.84 \%$ \\
\hline 5 & 167 & $24.26 \%$ \\
\hline 10 & 76 & $11.05 \%$ \\
\hline 15 & 56 & $8.14 \%$ \\
\hline 20 & 39 & $5.67 \%$ \\
\hline 25 & 19 & $2.76 \%$ \\
\hline 30 & 12 & $1.74 \%$ \\
\hline 35 & 19 & $2.76 \%$ \\
\hline 40 & 10 & $1.45 \%$ \\
\hline 45 & 6 & $0.87 \%$ \\
\hline 50 & 8 & $1.16 \%$ \\
\hline 55 & 7 & $1.02 \%$ \\
\hline 60 & 4 & $0.58 \%$ \\
\hline 65 & 3 & $0.44 \%$ \\
\hline 70 & 1 & $0.15 \%$ \\
\hline 75 & 1 & $0.15 \%$ \\
\hline 80 & 1 & $0.15 \%$ \\
\hline Total & 688 & $100 \%$ \\
\hline
\end{tabular}


$\underline{\text { Size, Age, and Growth }}$

Lengths of white sturgeon captured using setlines ranged from $47-233 \mathrm{~cm}$ FL, with a median length of $86.0 \mathrm{~cm}$ FL (Figure A-3). The length distribution of the setline catch was: $6 \%<70 \mathrm{~cm} \mathrm{FL}, 86 \% 70-109 \mathrm{~cm} \mathrm{FL}, 4 \% 110-137,2 \% 138-166$, and $1 \%>166 \mathrm{~cm} \mathrm{FL}$.

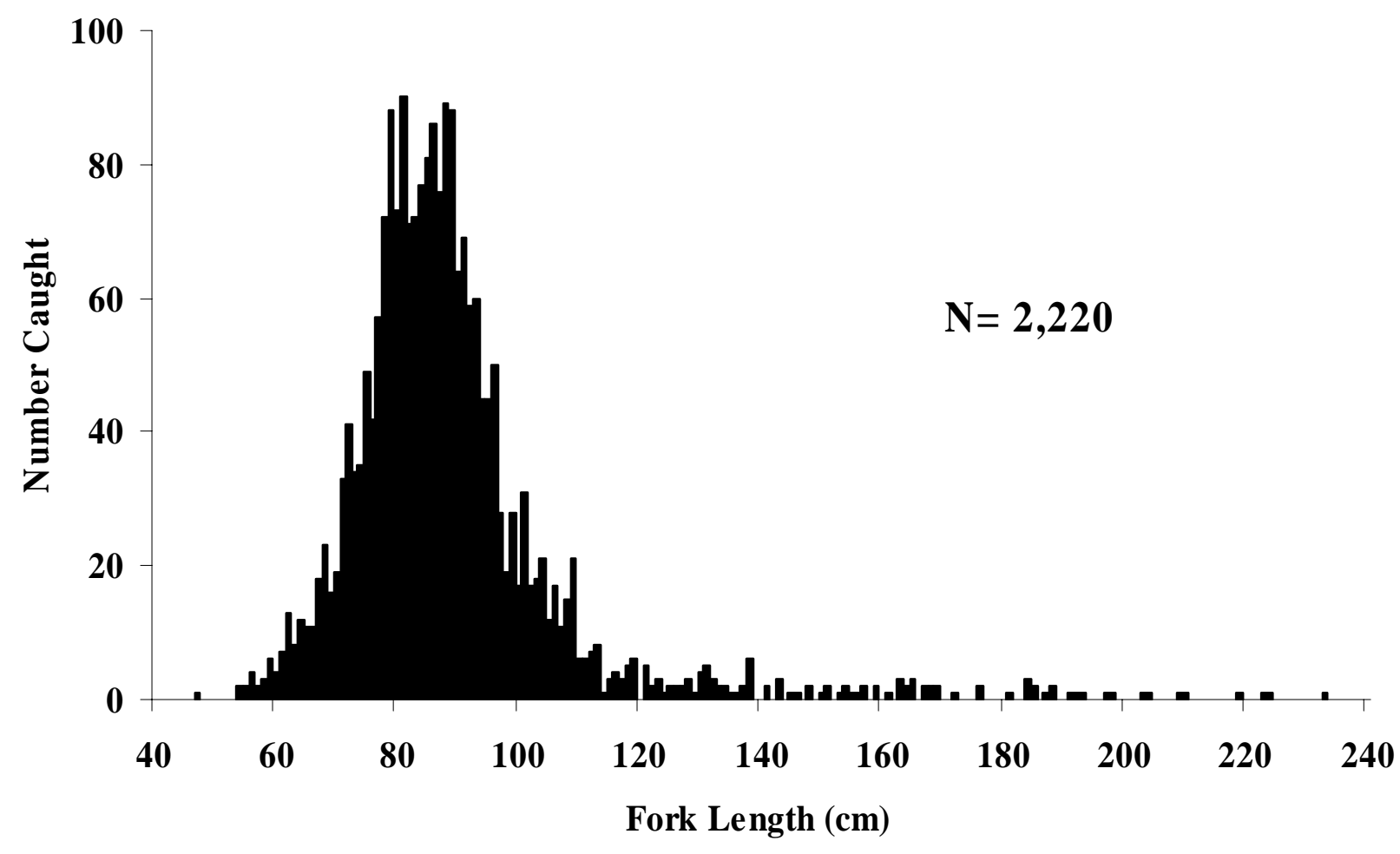

Figure A-3. Length frequency of white sturgeon captured by setline from John Day Reservoir during the 2007 stock assessment.

Weights of white sturgeon recorded from a sub-sample of fish captured by setline ranged from $0.5-84.0 \mathrm{~kg}$, with a median weight of $5.5 \mathrm{~kg}$. The relationship between fork length (L) and weight $(\mathrm{W})$ was described by the exponential function:

$$
W_{L}=0.827 e^{0.023^{*} L} \text { (Figure A-4). }
$$

Relative weight percentages calculated from a sub-sample of captured white sturgeon (from periods 2-3) ranged from $19-254 \%$ with a median relative weight percentage of $101 \%$ (Figure A-5). There was a significant difference (Mann-Whitney rank sum test, $\mathrm{P}<0.001$ ) in relative weight percentages of captured white sturgeon between sampling periods two and three in 2007. The median relative weight percentage was $103 \%$ during period $2,99 \%$ during period 3. 


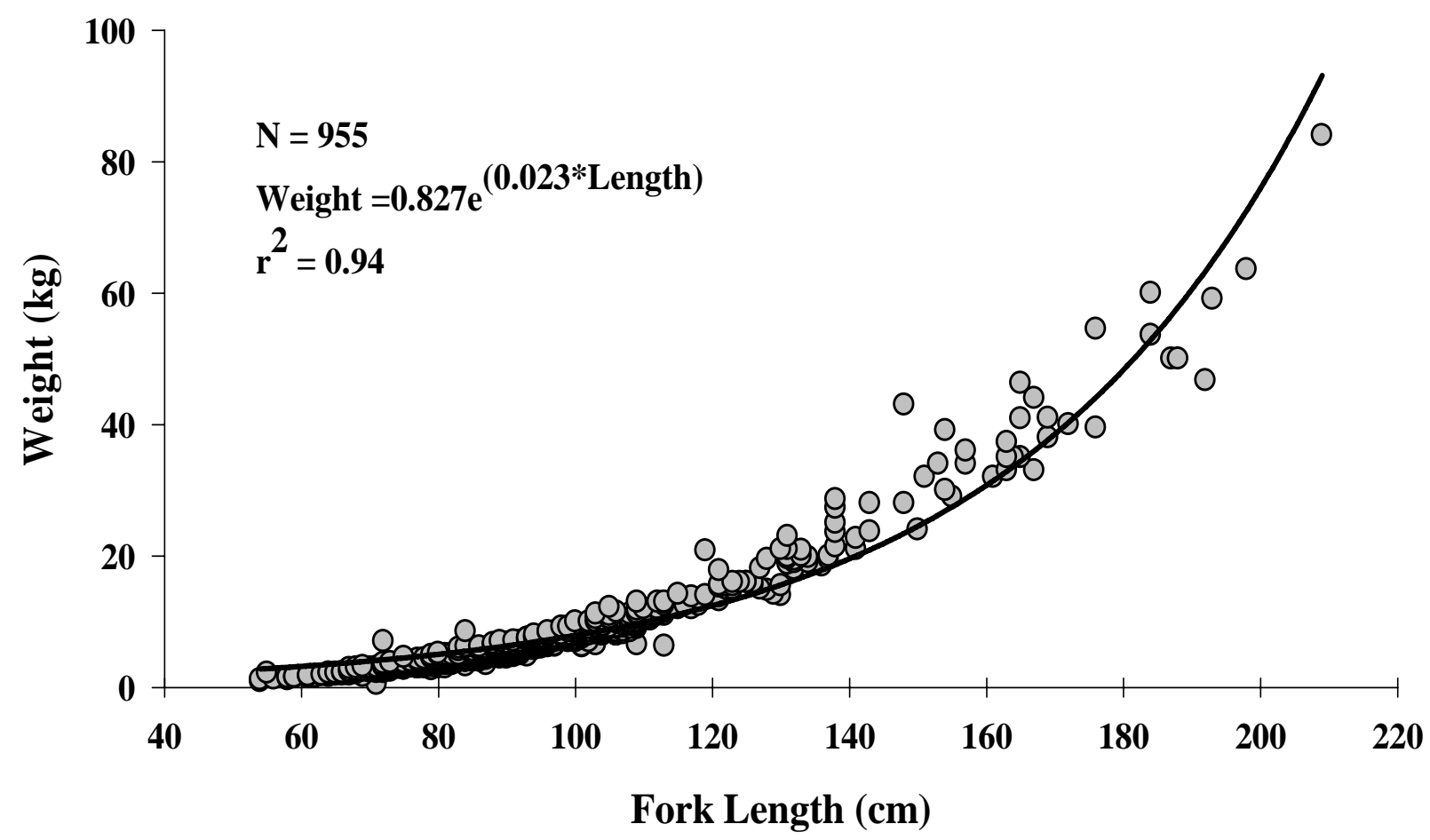

Figure A-4. Length-weight relationship of white sturgeon captured with setlines during stock assessment sampling in John Day Reservoir, 11 June through 23 August 2007 (periods 2-3).

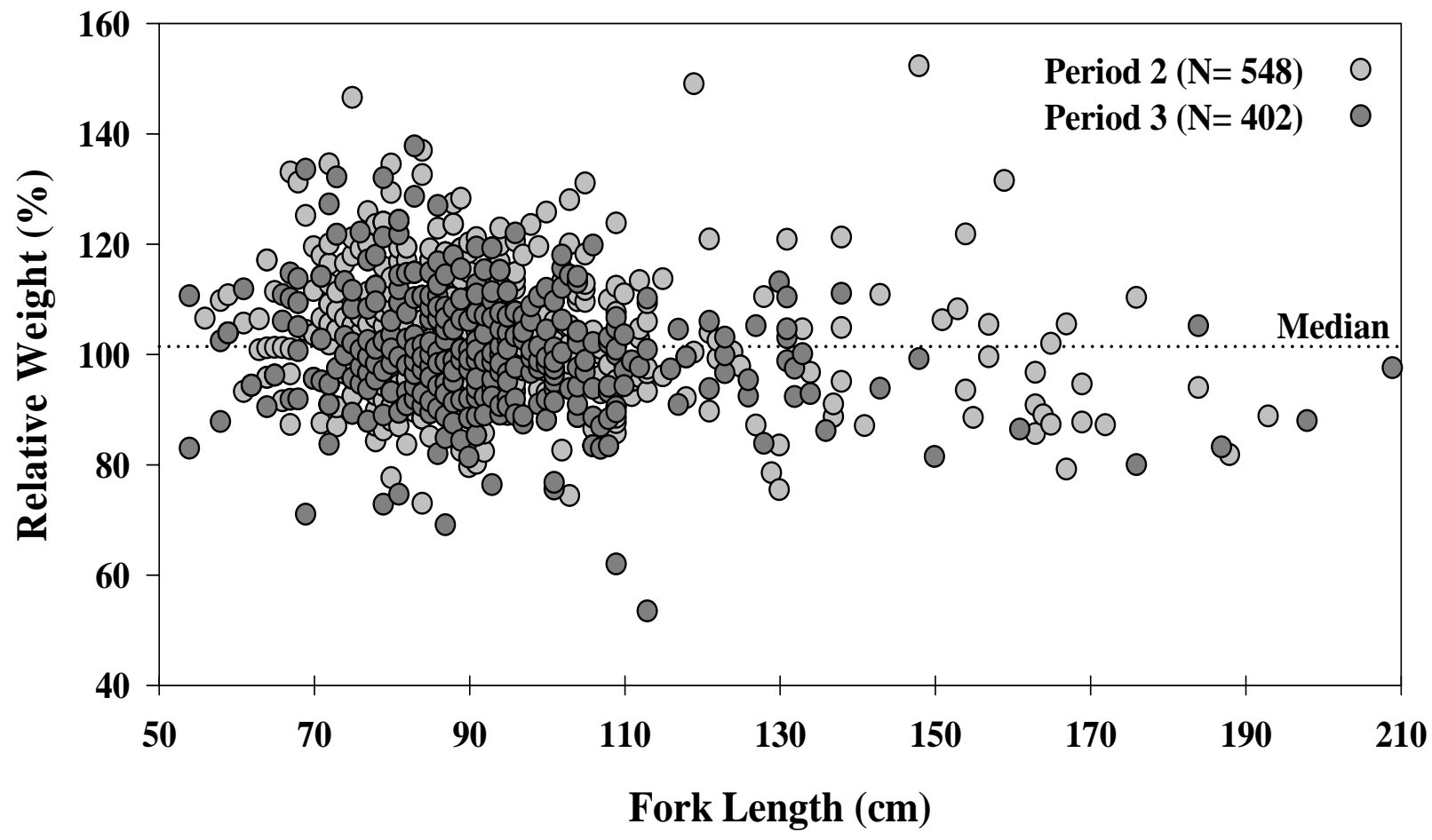

Figure A-5. Relative weights by period of white sturgeon captured with setlines during stock assessment sampling, 11 June through 23 August 2007. 
We estimated ages for 104 white sturgeon captured from John Day Reservoir during the 2007 stock assessment. Age estimates ranged from 7-61 years, with a median age of 20 years. Variation between ages assigned by readers was high (Table A-5). There was 19\% agreement in the final ages assigned by the two readers. The von Bertalanffy growth function describing size at age for white sturgeon from John Day Reservoir in 2007 was:

$$
\mathrm{L}_{\mathrm{x}}=191.7\left[1-\mathrm{e}^{-0.0482(\mathrm{x}-2.4)}\right] \text { (Figure A-6). }
$$

Annual growth increments (AGI) for white sturgeon from John Day Reservoir were estimated from 1) the 2004 and 2007 von Bertalanffy growth functions, and 2) from PIT tagged sturgeon recaptured during 1987-2007 (Figure A-7). Predicted AGIs estimated from the 2004 and 2007 von Bertalanffy growth functions decreased as fish size increased, ranging from approximately $6.5 \mathrm{~cm} /$ year for white sturgeon 41-60 cm FL, to approximately $0.5 \mathrm{~cm} /$ year for fish greater that $180 \mathrm{~cm}$ FL. AGIs estimated from recaptured fish showed varied growth rates throughout all sizes with an increasing trend until approximately $121-140 \mathrm{~cm}$. Growth rates declined between 121-140 and 181-200, after which growth rates again increased. Estimated growth rates of individual fish ranged from a low of $0 \mathrm{~cm} /$ year to a high of $29.3 \mathrm{~cm} /$ year. Growth for white sturgeon 41-100 cm FL averaged $4.09 \mathrm{~cm} /$ year, increasing to $7.63 \mathrm{~cm} /$ year for fish 121-160 cm FL, then decreasing to $5.53 \mathrm{~cm} /$ year for white sturgeon over $181 \mathrm{~cm} \mathrm{FL}$.

Table A-5. Discrepancies in aging of white sturgeon collected from Bonneville Reservoir during the 2006 stock assessment. The shaded row indicates when the two readers assigned an identical final age.

\begin{tabular}{|c|c|c|c|c|c|c|c|c|c|c|c|c|c|c|c|c|c|c|}
\hline \multirow[b]{2}{*}{$\begin{array}{c}\text { Age } \\
\text { Difference }\end{array}$} & \multicolumn{16}{|c|}{ Final Assigned Age } & \multirow[b]{2}{*}{$\begin{array}{c}\% \\
\text { Agreement }\end{array}$} & \multirow[b]{2}{*}{$\mathrm{N}$} \\
\hline & 7 & 8 & 9 & 10 & 11 & 12 & 13 & 14 & 15 & $\begin{array}{l}16- \\
18\end{array}$ & $\begin{array}{l}19- \\
21\end{array}$ & $\begin{array}{l}22- \\
24\end{array}$ & $\begin{array}{l}25- \\
27\end{array}$ & $\begin{array}{c}28- \\
30\end{array}$ & $\begin{array}{l}31- \\
33\end{array}$ & $>33$ & & \\
\hline-5 & & & & & & & & & & & & & & & & 1 & 1.0 & 1 \\
\hline-4 & & & & & & & & & & & & & & 1 & & & 1.0 & 1 \\
\hline-3 & & & & & & & & & & & & 1 & & & 1 & & 1.9 & 2 \\
\hline-2 & & & 1 & & & & & & & 1 & & & & & & & 1.9 & 2 \\
\hline-1 & 1 & & & & 1 & 2 & & & 2 & 1 & 1 & 3 & 3 & 1 & 1 & & 15.5 & 16 \\
\hline 0 & 1 & 4 & & 1 & & 2 & 1 & 3 & 2 & 3 & 1 & & 1 & & 1 & & 19.4 & 20 \\
\hline 1 & & 1 & & 1 & 1 & & 1 & 4 & 1 & 2 & 1 & 1 & 1 & 4 & & & 17.5 & 18 \\
\hline 2 & & & & & & & 1 & 1 & 1 & 5 & 2 & 2 & 2 & 3 & 1 & 1 & 18.4 & 19 \\
\hline 3 & & & & & & 1 & & & & & 1 & 2 & & & & 2 & 5.8 & 6 \\
\hline 4 & & & & & & & & & & 1 & 1 & 1 & 1 & & 1 & & 4.9 & 5 \\
\hline 5 & & & & & & & & & & 1 & & 1 & & & & 1 & 2.9 & 3 \\
\hline 6 & & & & & & & & & & 1 & & & 1 & & 1 & & 2.9 & 3 \\
\hline 7 & & & & & & & & & & & & 1 & & & & 2 & 2.9 & 3 \\
\hline 9 & & & & & & & & & & & & & & & 2 & 1 & 2.9 & 3 \\
\hline 17 & & & & & & & & & & & & & & & & 1 & 1.0 & 1 \\
\hline All & 2 & 5 & 1 & 2 & 2 & 5 & 3 & 8 & 6 & 15 & 7 & 12 & 9 & 9 & 8 & 9 & 100.0 & 103 \\
\hline
\end{tabular}




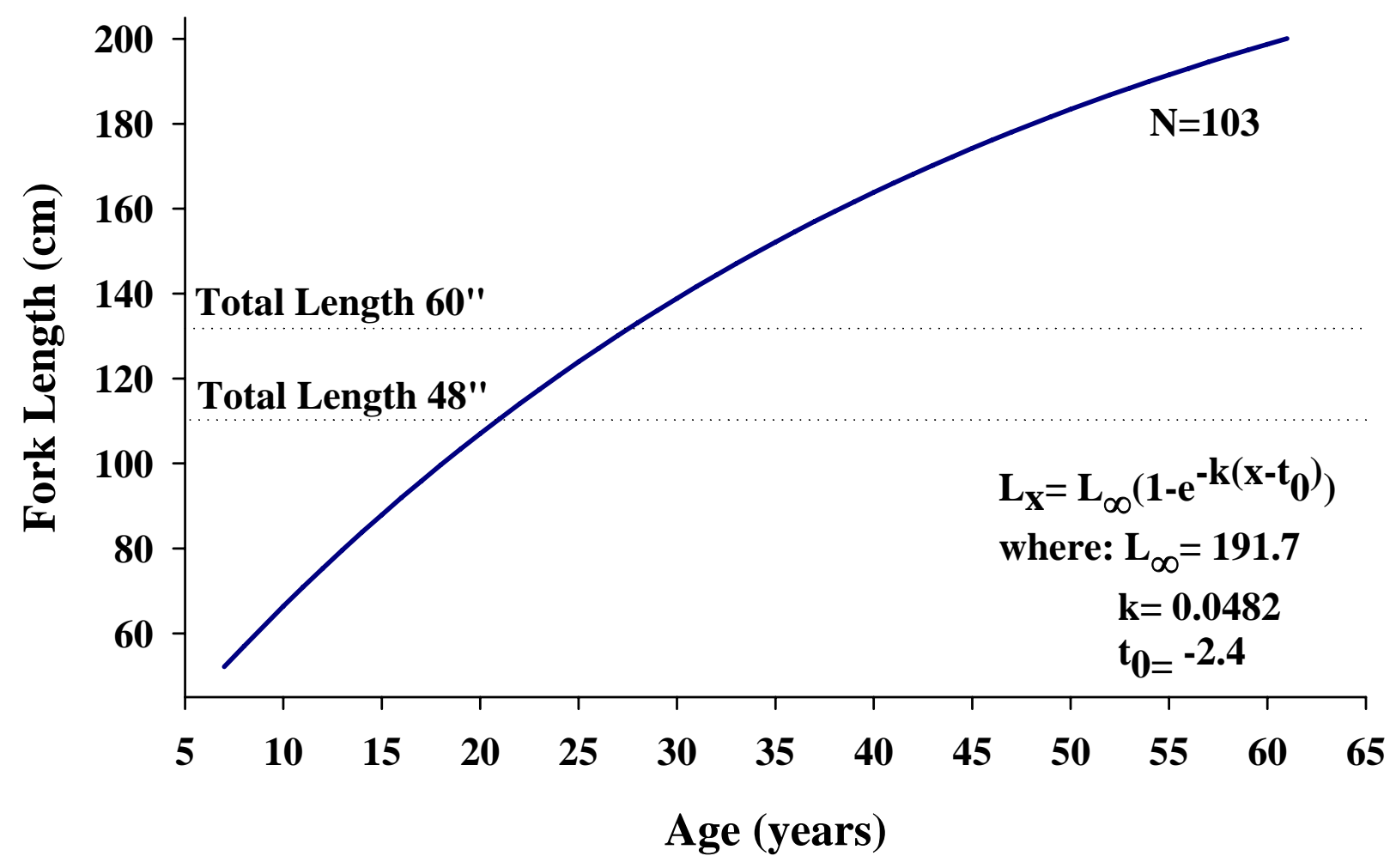

Figure A-6. von Bertalanffy growth function for white sturgeon collected from John Day Reservoir during the 2007 stock assessments.

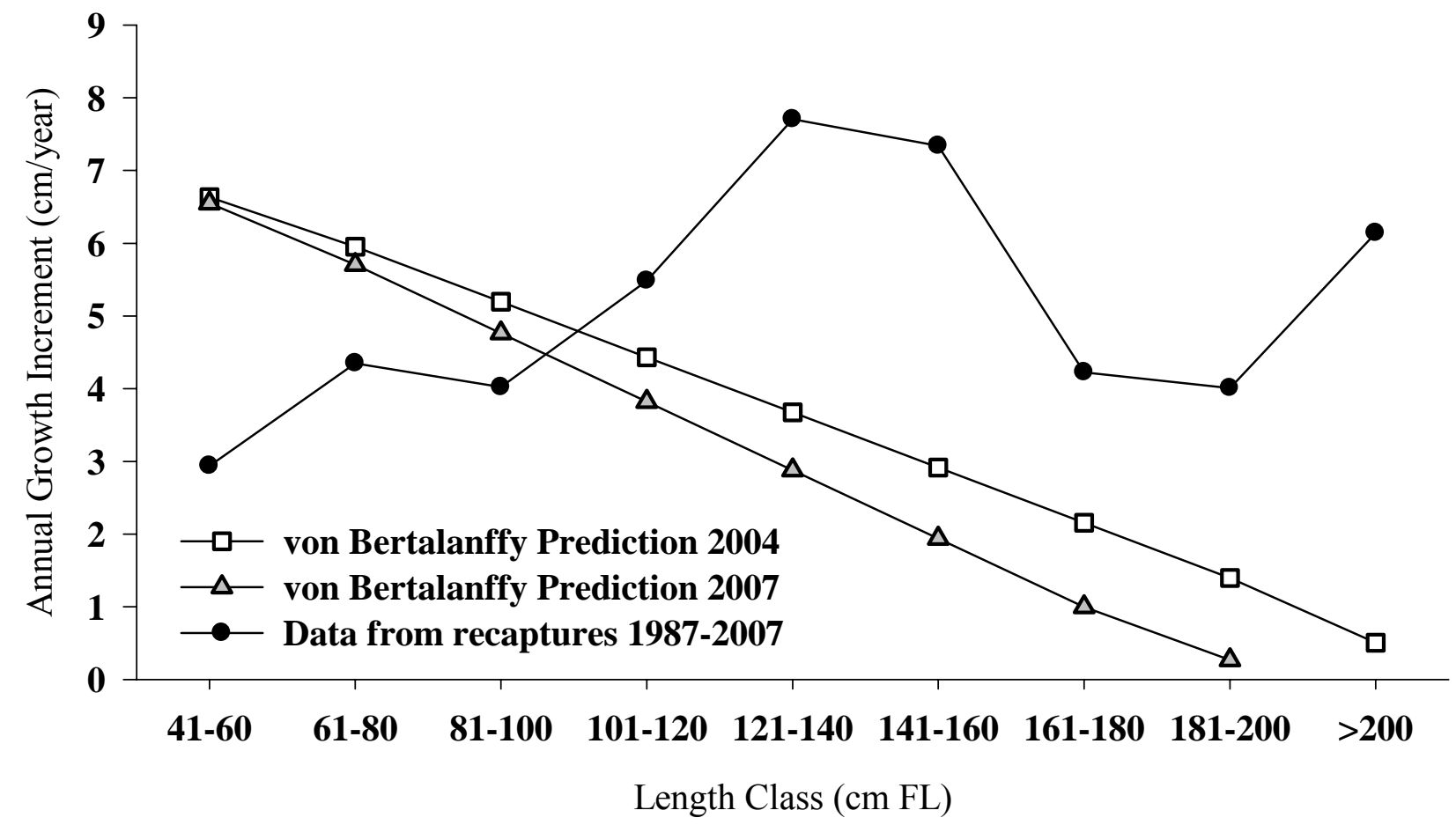

Figure A-7. Mean AGIs by length class predicted by the 2004 and 2007 von Bertalanffy growth functions, and mean AGIs calculated from recaptures of tagged fish from John Day Reservoir. 


\section{Abundance}

The estimated abundance of white sturgeon 70-109 cm FL was 36,798 (95\% CI: 31,84942,511; Table A-6). The estimated abundance of white sturgeon 54-69 cm FL was 2,762. The estimated abundances of white sturgeon 110-166 cm FL and greater than $166 \mathrm{~cm}$ FL were 2,222 and 841 respectively (Table A-7). The estimated abundance of legally harvestable fish (110-137 $\mathrm{cm}$ FL) was 1,587. The total population size of white sturgeon ( $\geq 54 \mathrm{~cm}$ FL) in John Day Reservoir in 2007 was estimated to be 42,622 (Table A-7; Figure A-8).

Table A-6. Mark/recapture data and Schnabel abundance estimate of white sturgeon 70-109 cm fork length in John Day Reservoir, 2007.

\begin{tabular}{cccccccc}
\hline $\begin{array}{c}\text { Period } \\
(\mathrm{t})\end{array}$ & $\begin{array}{c}\text { Catch } \\
(\mathrm{C})\end{array}$ & $\begin{array}{c}\text { Marks } \\
(\mathrm{M})\end{array}$ & $\begin{array}{c}\text { Recaps } \\
(\mathrm{R})\end{array}$ & $\begin{array}{c}\text { Mortalities/Harvest } \\
\text { Unmarked }\end{array}$ & $\begin{array}{c}\text { Marks at Large } \\
(\mathrm{Mt})\end{array}$ & $\begin{array}{c}\text { Estimate } \\
\mathrm{SUM}\left(\mathrm{M}_{\mathrm{t}}{ }^{*} \mathrm{C}\right) /(\mathrm{R}+1)\end{array}$ \\
\hline 1 & 3,919 & 3,085 & $--^{\mathrm{a}}$ & 34 & 4 & 0 & \\
2 & 1,073 & 981 & 84 & 0 & 0 & 3,081 & 38,892 \\
3 & 844 & 741 & 98 & 0 & 0 & 4,062 & 34,629 \\
Sum & 5,836 & 4,807 & 182 & & & $\begin{array}{c}\text { Estimate } \\
\text { 95\% CI (lower) }\end{array}$ & 36,798 \\
& & & & & & $95 \%$ CI (upper) & 31,849 \\
& & & & & & & \\
\end{tabular}

${ }^{a}$ White sturgeon recaptured during period 1 were not included in the Schnabel estimate.

Table A-7. Estimated abundances of white sturgeon in John Day Reservoir from the 2007 stock assessment. Confidence intervals are given for the size group for which a Schnabel estimate was calculated, and not for size groups for which abundance was estimated by expansion from the length-frequency of the setline catch.

\begin{tabular}{|c|c|c|c|}
\hline \multicolumn{2}{|c|}{ Size Range cm FL } & 2007 Estimate $(95 \% \mathrm{CI})$ & Relative Abundance (\%) \\
\hline $54-69$ & $(24 "-30 " \mathrm{TL})$ & 2,762 & 6 \\
\hline $70-109$ & (31"-48" TL) & 36,798 & \\
\hline & & $(31,849-42,511)$ & 87 \\
\hline $110-166$ & $(48 "-72 " \mathrm{TL})$ & 2,222 & 5 \\
\hline $167+$ & $(72 ”+T L)$ & 841 & 2 \\
\hline $54+$ & $(>24 ”, T L)$ & 42,622 & -- \\
\hline $103-137$ & $(48 "-60 " \mathrm{TL})^{\mathrm{a}}$ & 1,587 & 4 \\
\hline
\end{tabular}

${ }^{a}$ Size range of legally harvestable fish in both the sport and commercial fisheries. 


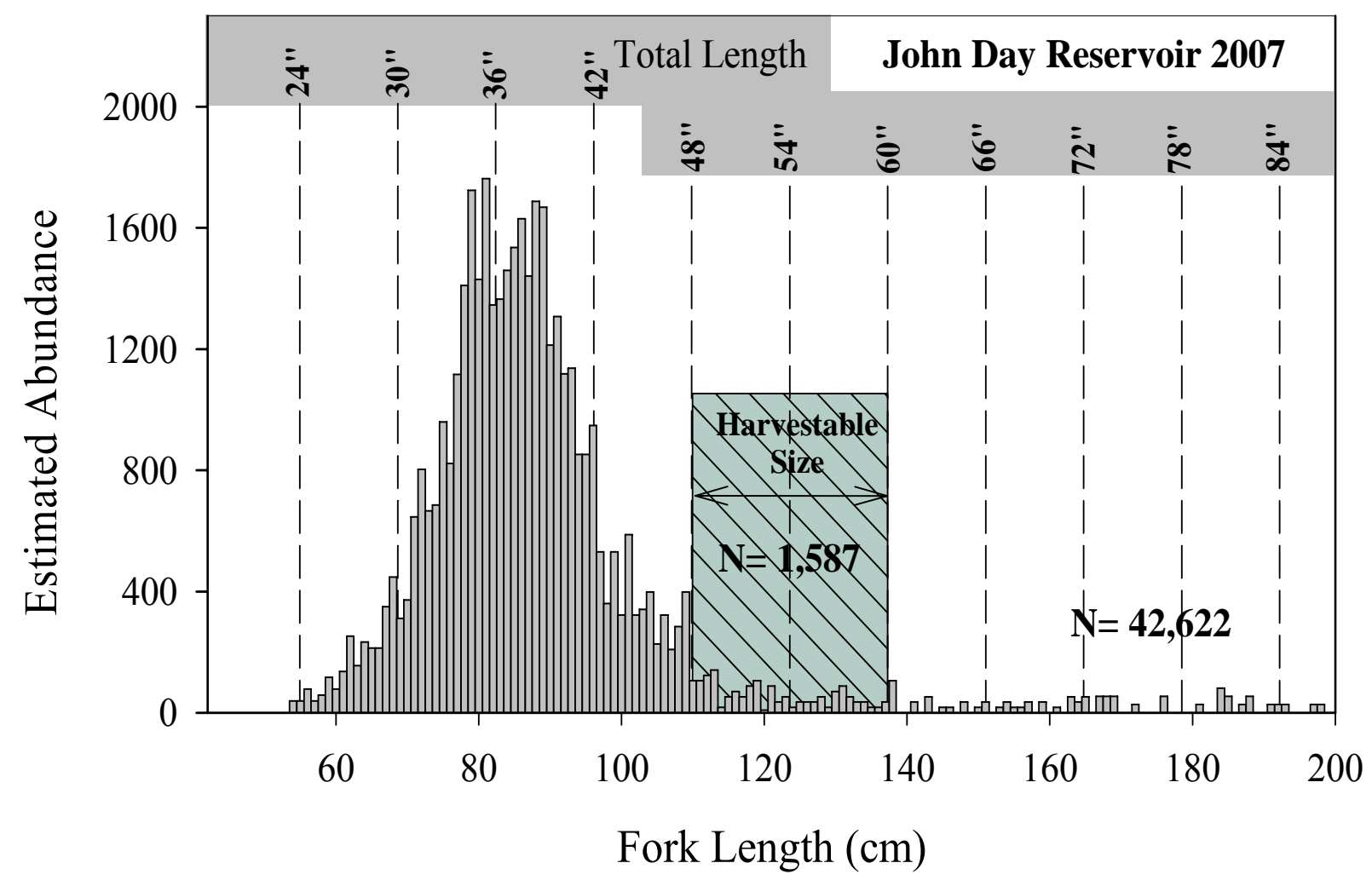

Figure A-8. Length-frequency distribution of white sturgeon ( $\geq 54 \mathrm{~cm}$ FL) in John Day Reservoir based on the 2007 stock assessment.

\section{Age-0 Indexing}

During age-0 indexing, in all reservoirs combined, 389 white sturgeon were captured in 151 individual net sets. Nets were fished for a combined 3,452 hours, with an average of 23.0 hours per set. Of the 389 white sturgeon captured, 32 (8\%) were classified as age-0. Age-0 white sturgeon were captured in each reservoir sampled except John Day in 2007. Captured white sturgeon ranged in length from 13.4 to $105.0 \mathrm{~cm}$ FL (Figure A-9), and all age-0 white sturgeon (determined by aging) were $\leq 30.0 \mathrm{~cm} \mathrm{FL}$ (mean $\mathrm{cm} \mathrm{FL}=18.2,95 \% \mathrm{CI}$ from 15.5 to $20.8 \mathrm{~cm} \mathrm{FL})$. We applied a total of 327 (84\% of total catch) PIT tags to white sturgeon from Bonneville, The Dalles, John Day, and McNary reservoirs in 2007 . No sturgeon less than $30 \mathrm{~cm}$ FL received a PIT tag. Incidental catch of other fish species during age-0 sampling is presented in appendix Table A-14.

\section{$\underline{\text { McNary Reservoir }}$}

A total of four white sturgeon were captured in 36 individual net sets. Of the four white sturgeon captured, $2(50 \%)$ were classified as age- 0 . White sturgeon $\geq$ age- 1 were captured in $11 \%$ of the sets, while age- 0 white sturgeon were captured in $5.6 \%$ of the sets. The CPUE was 0.11 for all white sturgeon and 0.056 for age- 0 white sturgeon (Table A-8). 


\section{$\underline{\text { John Day Reservoir }}$}

A total of 13 white sturgeon were captured in 40 individual net sets. Of the 13 white sturgeon captured, none were classified as age- 0 . White sturgeon $\geq$ age- 1 were captured in $22.5 \%$ of the sets. The CPUE was 0.33 for all white sturgeon (Table A-8).

\section{$\underline{\text { The Dalles Reservoir }}$}

A total of 75 white sturgeon were captured in 36 individual net sets. Of the 75 white sturgeon captured, $9(12 \%)$ were classified as age- 0 . White sturgeon $\geq$ age- 1 were captured in $47 \%$ of the sets, while age- 0 white sturgeon were captured in $14 \%$ of the sets. The CPUE was 2.08 for all white sturgeon and 0.25 for age- 0 white sturgeon (Table A-8).

$\underline{\text { Bonneville Reservoir }}$

A total of 297 white sturgeon were captured in 39 individual net sets. Of the 297 white sturgeon captured, $21(7 \%)$ were classified as age- 0 . White sturgeon $\geq$ age-1 were captured in $95 \%$ of the sets, while age- 0 white sturgeon were captured in $31 \%$ of the sets. The CPUE was 7.62 for all white sturgeon and 0.54 for age- 0 white sturgeon (Table A-8). 


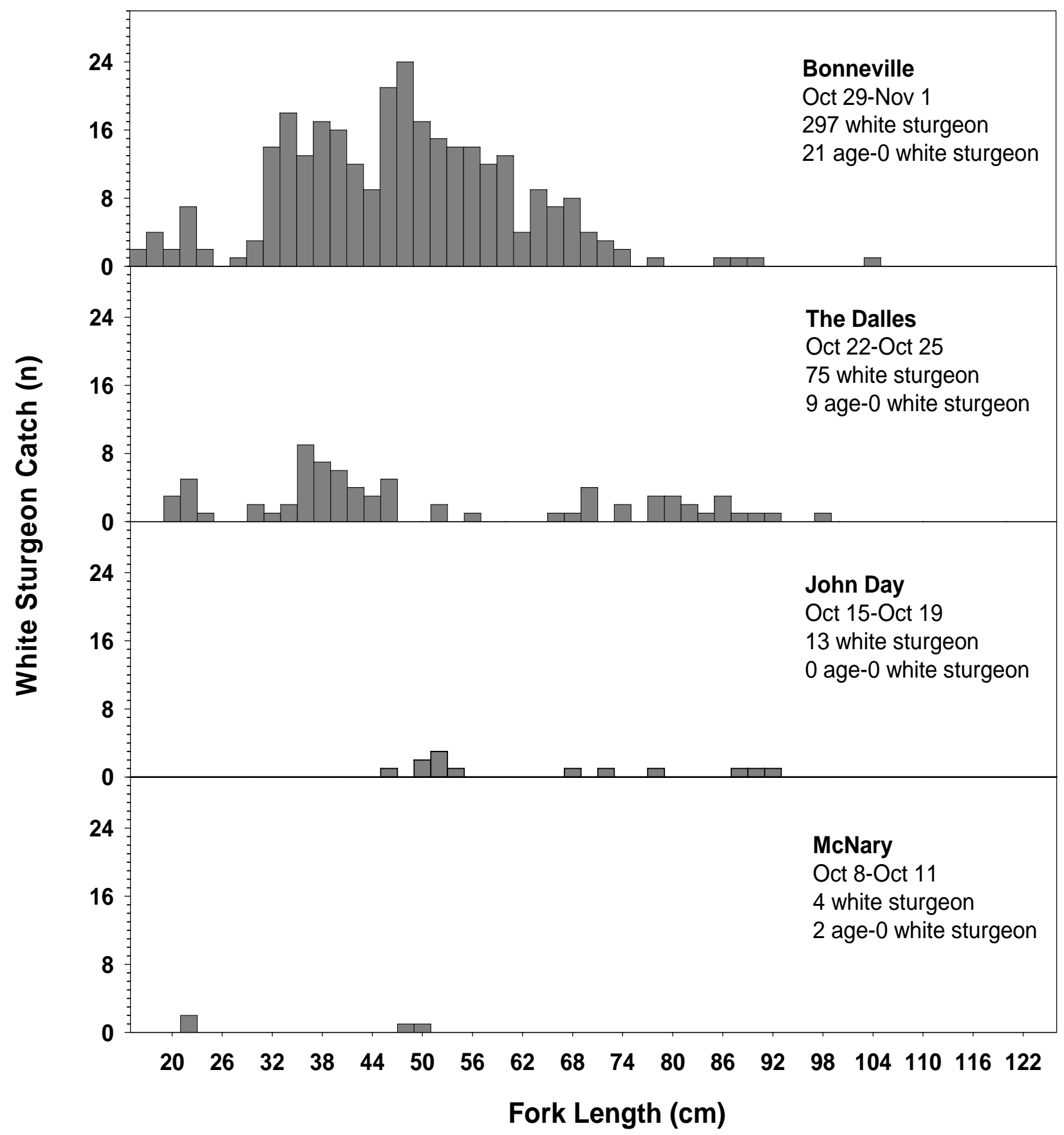

Figure A-9. Length-frequency distributions and catch data for white sturgeon captured during age-0 indexing, October 2007. 
Table A-8. Effort and catch of white sturgeon in Columbia River reservoirs during age-0 sampling, October and November 2007.

\begin{tabular}{lrrrr}
\hline & \multicolumn{4}{c}{ Reservoir } \\
\cline { 2 - 5 } Parameter & BON & TDA & JDY & MCN \\
\hline Gill Net Sets & 39 & 36 & 40 & 36 \\
Total Hours Fishing & 905 & 848 & 881 & 819 \\
White Sturgeon Catch (all sizes) & 297 & 75 & 13 & 4 \\
White Sturgeon Catch (Age-0) & 21 & 9 & 0 & 2 \\
White Sturgeon / Set (CPUE) & 7.62 & 2.08 & 0.33 & 0.11 \\
Age-0 White Sturgeon /Set (CPUE) & 0.54 & 0.25 & 0.00 & 0.06 \\
Prop. of positive sets (all sizes) & 0.95 & 0.47 & 0.23 & 0.11 \\
Prop. of positive sets (Age-0) & 0.31 & 0.14 & 0.00 & 0.06 \\
\hline
\end{tabular}

\section{DISCUSSION}

\section{Stock Assessment}

The estimated abundance of white sturgeon $\geq 54 \mathrm{~cm}$ FL in John Day Reservoir in 2007 (42,622 fish) was 1.3\% higher than in 2004 (42,050 fish; Table A-9). The 2007 stock assessment indicated substantial increases in both the legal and over-legal size classes (Table A-10; Figure A-10). There was a $45 \%$ increase in the sport-legal size class and a $200 \%$ increase in the overlegal size class from 2004 levels. Offsetting these increases was a substantial decrease in the 54$69 \mathrm{~cm}$ FL size class, which decreased in abundance by 76\% from 2004 (Table A-9).

Due to the low encounter rate for over-legal size white sturgeon, caution should be taken when interpreting the estimated abundance of this size class. It may be more appropriate to consider trends in abundance for these fish rather than estimated abundance.

The decrease in abundance of small fish (54-69 cm FL) is important, and may be indicative of few fish recruiting to the juvenile population. Lack of recruitment is supported by our age- 0 index efforts, which show that since 2000 , only one age- 0 white sturgeon has been captured in John Day Reservoir. A continued lack of spawning success coupled with a decrease in juvenile recruitment in the reservoir would result in a population structure out of equilibrium (i.e., greater proportion of large/old white sturgeon relative to small/young white sturgeon). Without juvenile recruitment and subsequent replacement of legal-sized fish, further restrictions on harvest within the reservoir are likely. Abundance estimates from 1987-2007 for Zone 6 reservoirs and the Hanford reach of McNary Reservoir are presented in Appendix Table A-15. 
Table A-9. Summary of white sturgeon abundance by size class, John Day Reservoir, 2004 and 2007. Abundance values in bold type were derived from Schnabel estimates; non-bold abundance values were estimated by expansion.

\begin{tabular}{|c|c|c|c|c|}
\hline Size Range cm FL & 2004 Estimate & 2007 Estimate & Difference & $\%$ Difference \\
\hline$(24 "-30 " \mathrm{TL})$ & 11,671 & 2,762 & $-8,909$ & -76 \\
\hline$(31 "-47 " \mathrm{TL})$ & 28,794 & 36,798 & 8,004 & 28 \\
\hline $110-137^{\mathrm{a}} \quad(48 "-60 " \mathrm{TL})$ & 1,094 & 1,587 & 493 & 45 \\
\hline $138-166 \quad(61 "-72 " \mathrm{TL})$ & 185 & 635 & 450 & 243 \\
\hline$(73 ”+T L)$ & 306 & 841 & 535 & 175 \\
\hline All Sizes & 42,050 & 42,622 & 572 & 1 \\
\hline
\end{tabular}

${ }^{\mathrm{a}}$ The 110-137 cm FL group represents the size range of legally harvestable fish (sport and commercial)

Table A-10. Summary of abundance estimates by harvest category, John Day Reservoir 2004 \& 2007.

\begin{tabular}{|c|c|c|c|c|}
\hline Size Range & $\begin{array}{c}2004 \\
\text { Estimate }\end{array}$ & $\begin{array}{c}2007 \\
\text { Estimate }\end{array}$ & Change & $\%$ Change \\
\hline$(24 "-47 " \mathrm{TL})$ & 40,465 & 39,560 & -905 & -2 \\
\hline Sport/Comm Legal (48"-60" TL) & 1,094 & 1,587 & 493 & 45 \\
\hline Over-legal & 491 & 1,476 & 985 & 201 \\
\hline
\end{tabular}




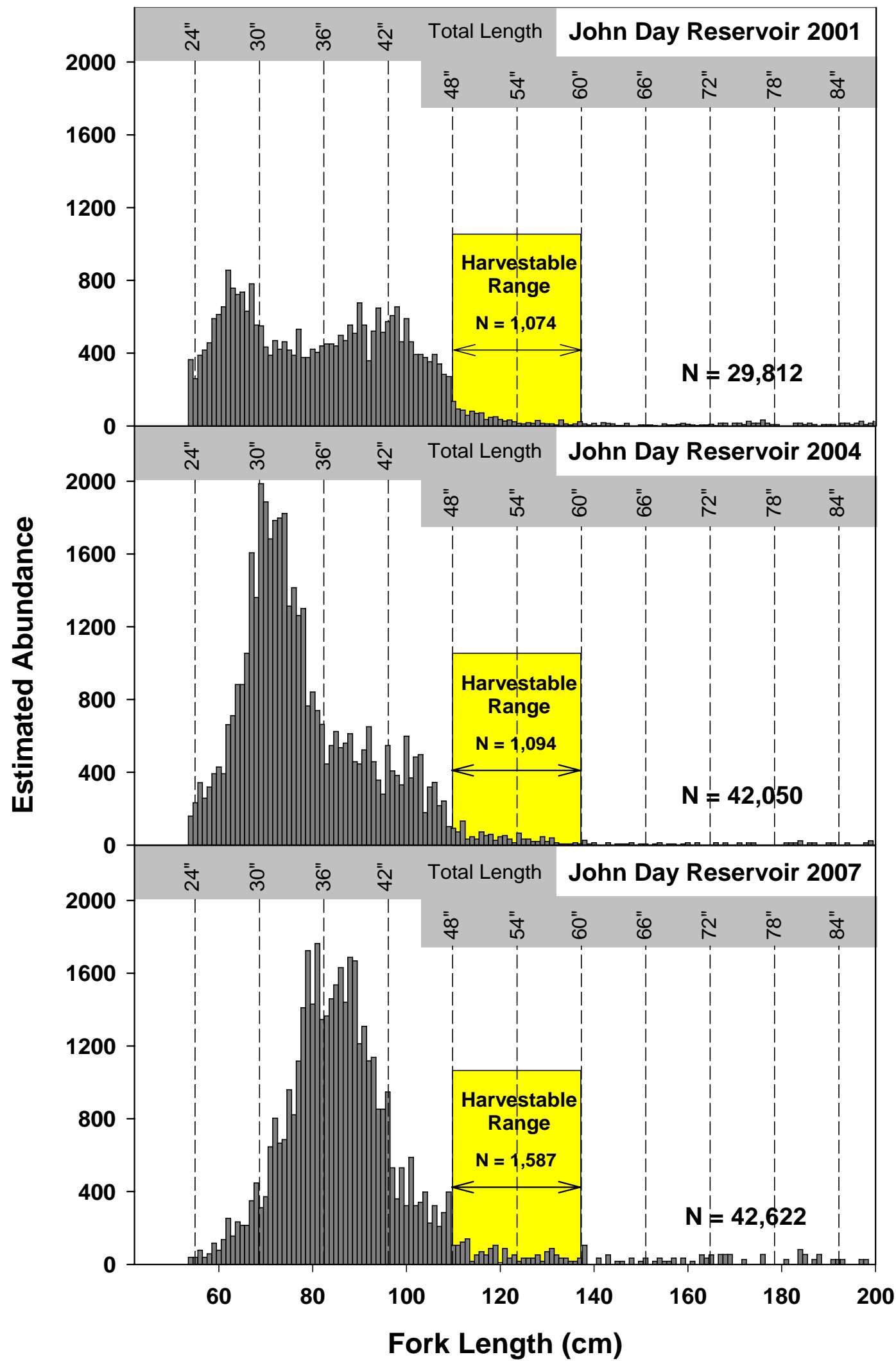

Figure A-10. Abundance by 1-cm fork length intervals for the 2001, 2004, and 2007 John Day Reservoir stock assessments. 
Indicators of body condition, such as relative weight, can provide an indirect means of evaluating ecological relations and the effects of various management strategies, especially when making size-specific comparisons within or among populations. The overall mean relative weight of white sturgeon in John Day Reservoir has increased slightly since 1996. Mean relative weight in 1996, 2001, 2004 and 2007, was 97.3, 97.3, 102.9 and 102.1 respectively (Table A11). The increase in overall relative weights is not consistent over all size classes; in the $160+\mathrm{cm}$ FL size classes, mean relative weights fluctuate considerably. This is likely due to the small number of samples in that size category. Reasons for the observed increase in overall relative weights are unknown. Further studies examining size-specific diet and food web dynamics may provide some insight.

Table A-11. Condition of white sturgeon caught using setlines during stock assessments in John Day Reservoir, 1996, 2001, 2004 and 2007.

\begin{tabular}{cccccc}
\hline & \multicolumn{5}{c}{ Mean Relative Weight $\left(\mathrm{W}_{\mathrm{r}}\right)$} \\
\cline { 2 - 6 } Year & $70-95 \mathrm{~cm} \mathrm{FL}$ & $96-137 \mathrm{~cm} \mathrm{FL}$ & $138-159 \mathrm{~cm} \mathrm{FL}$ & $160+\mathrm{cm} \mathrm{FL}$ & \\
\hline 1996 & 97.97 & 97.21 & 97.69 & 94.20 & 97.39 \\
2001 & 106.65 & 89.70 & 83.78 & 75.90 & 97.31 \\
2004 & 102.89 & 102.88 & 103.21 & 103.17 & 102.88 \\
2007 & 103.31 & 99.78 & 106.05 & 91.32 & 102.10 \\
\hline
\end{tabular}

White sturgeon captured and aged during the 2007 John Day stock assessment were estimated to be older than white sturgeon (of similar sizes) captured and aged during previous John Day stock assessments. This trend in age estimation can be seen by examining the von Bertalanffy growth functions from 2001, 2004, and 2007 (Figure A-11). Based on the age estimates and the resulting von Bertalanffy growth functions, a legal size white sturgeon measuring $110 \mathrm{~cm}$ FL (48 inches total length) would be estimated at approximately 12 years old using the 2001 growth function, 15 years using the 2004 growth function, and 20 years old using the 2007 growth function. This represents a $67 \%$ increase in the estimated age of the hypothetical fish from 2001 to 2007.

The assigning of older ages in recent years was also observed in The Dalles and Bonneville reservoirs (Chapman and Hughes, 2007; Hughes et al., 2006). One explanation may be an unintentional bias towards older age estimates due to our awareness that past readings tended to underestimate the age of individual fish, consequently predicting faster growth (Rien and Beamesderfer, 1994; Kern et al., 2003). 


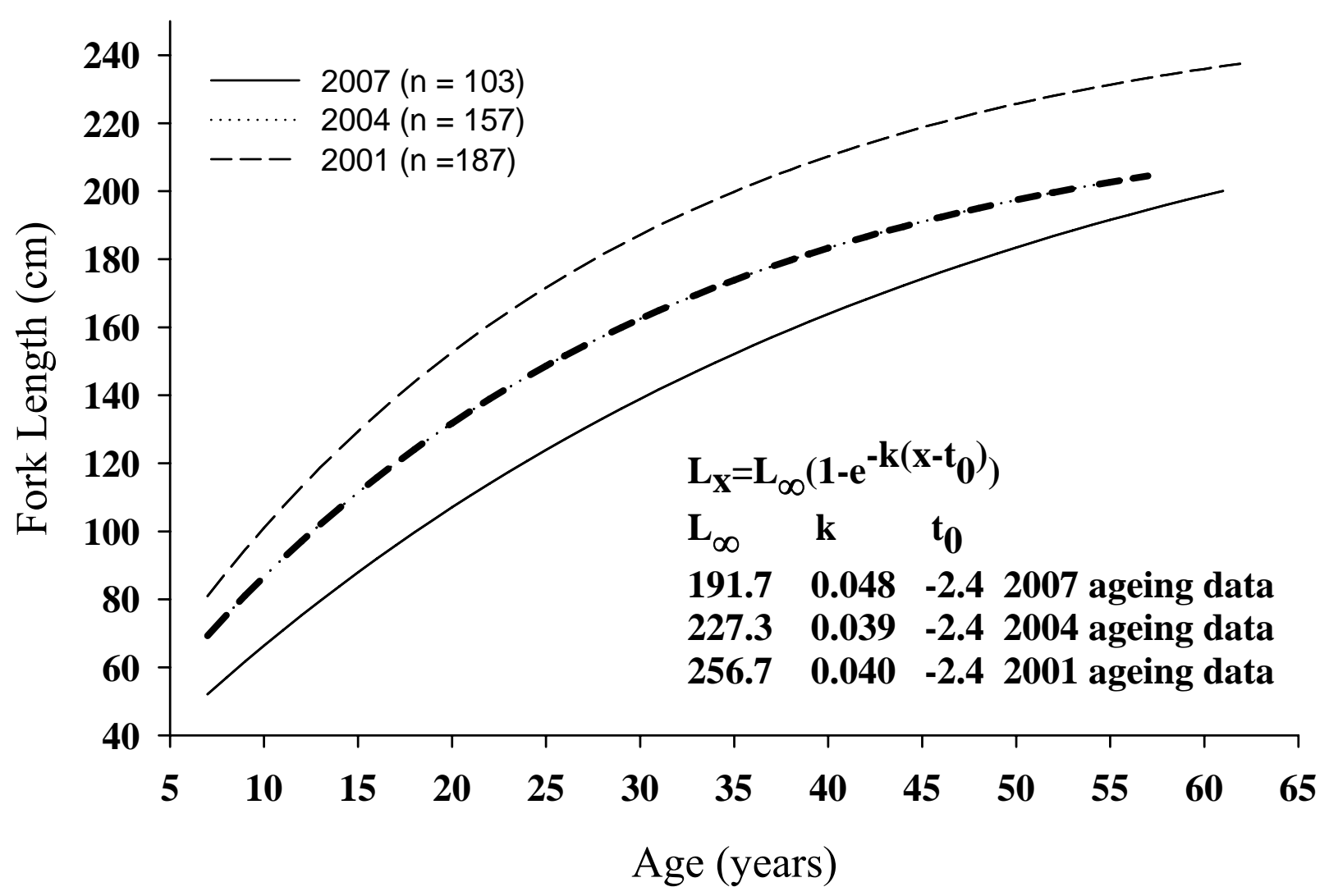

Figure A-11. Comparison of von Bertalanffy growth functions for white sturgeon collected from John Day Reservoir during 2001, 2004, and 2007.

Data collected from marked and recaptured fish in John Day Reservoir revealed a different pattern of growth than was predicted from the von Bertalanffy growth functions parameterized using 2004 and 2007 age estimates (Figure A-7). Smaller fish (41-60 cm FL) appear to grow at approximately one half the rate predicted from the von Bertalanffy growth function. Further, beginning at approximately $80 \mathrm{~cm}$ FL, white sturgeon in John Day Reservoir appear to experience an increase in growth rate, which is not apparent from the AGIs predicted from aging. Growth rate continues to increase until approximately 120-140 cm FL, where annual growth rate begins to decrease again (Figure A-7). The von Bertalanffy growth function (and therefore the AGIs predicted from the von Bertalanffy growth function) assumes a strictly decreasing growth rate as fish grow older. Recapture data suggest that white sturgeon in John Day Reservoir do not exhibit this pattern. These findings are consistent with what we found in The Dalles Reservoir in 2002 and 2005 and in Bonneville Reservoir in 2003 and 2006 (Chapman and Hughes-Weaver, 2007; Hughes et al., 2006).

Difficulties in obtaining accurate and consistent age data for white sturgeon, in addition to discrepancies found when comparing predicted and actual growth rates, highlight the need to identify and develop more objective methods for quantifying age and growth. Inaccurate growth data can have significant management implications, as current management decisions in John Day Reservoir are based on the abundance and growth of white sturgeon below, within, and above the legal size slot of 96-137 cm FL (48"-60" TL) for both sport and commercial fisheries. 


\section{Age-0 Indexing}

During 2007, recruitment of age-0 white sturgeon was detectable in each reservoir sampled except John Day. This pattern of recruitment is similar to general patterns observed in the past (Table A-12), with Bonneville Reservoir showing the highest level of recruitment, followed by The Dalles, McNary, and then John Day. This year continued the trend of poor recruitment in John Day Reservoir, specifically. In only one of the past eight years (2006) has there been any detectable recruitment of white sturgeon in John Day reservoir. A continued lack of spawning success in John Day Reservoir would result in a population structure out of equilibrium (only large/old fish, no small/young fish) and could lead to further restrictions on harvest within the reservoir.

Table A-12. Proportion of positive sets $\left(\mathrm{E}_{\mathrm{P}}\right)$ for age-0 $(\leq 30 \mathrm{~cm} \mathrm{FL})$ white sturgeon in upper Columbia and Snake river reservoirs 1997-2007.

\begin{tabular}{ccccccc}
\hline Year & Bonneville $^{\mathrm{a}}$ & The Dalles & John Day & McNary & Ice Harbor & Little Goose \\
\hline 1997 & -- & 0.74 & 0.53 & -- & 0.00 & -- \\
1998 & -- & 0.65 & 0.08 & -- & -- & 0.32 \\
1999 & -- & 0.67 & 0.22 & 0.08 & 0.03 & 0.08 \\
2000 & -- & 0.14 & 0.00 & 0.00 & 0.00 & 0.00 \\
2001 & -- & 0.00 & 0.00 & 0.00 & 0.00 & 0.00 \\
2002 & -- & 0.17 & 0.00 & 0.06 & 0.00 & 0.00 \\
2003 & -- & 0.00 & 0.00 & 0.00 & 0.00 & 0.00 \\
2004 & -- & 0.06 & 0.00 & 0.00 & 0.00 & 0.00 \\
2005 & -- & 0.03 & 0.00 & 0.03 & 0.00 & 0.00 \\
2006 & 0.69 & 0.47 & 0.01 & 0.06 & -- & - \\
2007 & 0.31 & 0.14 & 0.00 & 0.06 & -- & -
\end{tabular}

${ }^{a}$ Prior to 2006, USGS conducted age-0 trawl surveys in Bonneville Reservoir.

In the impounded lower Columbia River, water velocity, which is heavily influenced by dam discharge, appears to play an important role in white sturgeon spawning success (Parsley 1993; Parsley et al., 1993; Parsley and Beckman, 1994). Data from age-0 indexing, combined with dam discharge data, suggest that higher discharge rates (which create the physical conditions required for successful spawning by sturgeon) result in higher levels of recruitment to age-0 (Figure A-12). When the average daily discharge rate at McNary Dam during May-July (the spawning period of white sturgeon in the lower Columbia River) approaches or exceeds 250 $\mathrm{kcfs}$, there was a detectible level of recruitment in all reservoirs sampled. In 10 years of age- 0 sampling, the only exception to this was in 2002, when average discharge rates were greater than $250 \mathrm{kcfs}$ and recruitment was detected in only The Dalles Reservoir.

These data support past findings that discharge rates of approximately $250 \mathrm{kcfs}$ or greater during the spawning period create physical conditions (e.g. water velocity and turbulence) which increase the likelihood of successful recruitment of white sturgeon in the reservoir environments between McNary and Bonneville dams (Parsley 1993). 


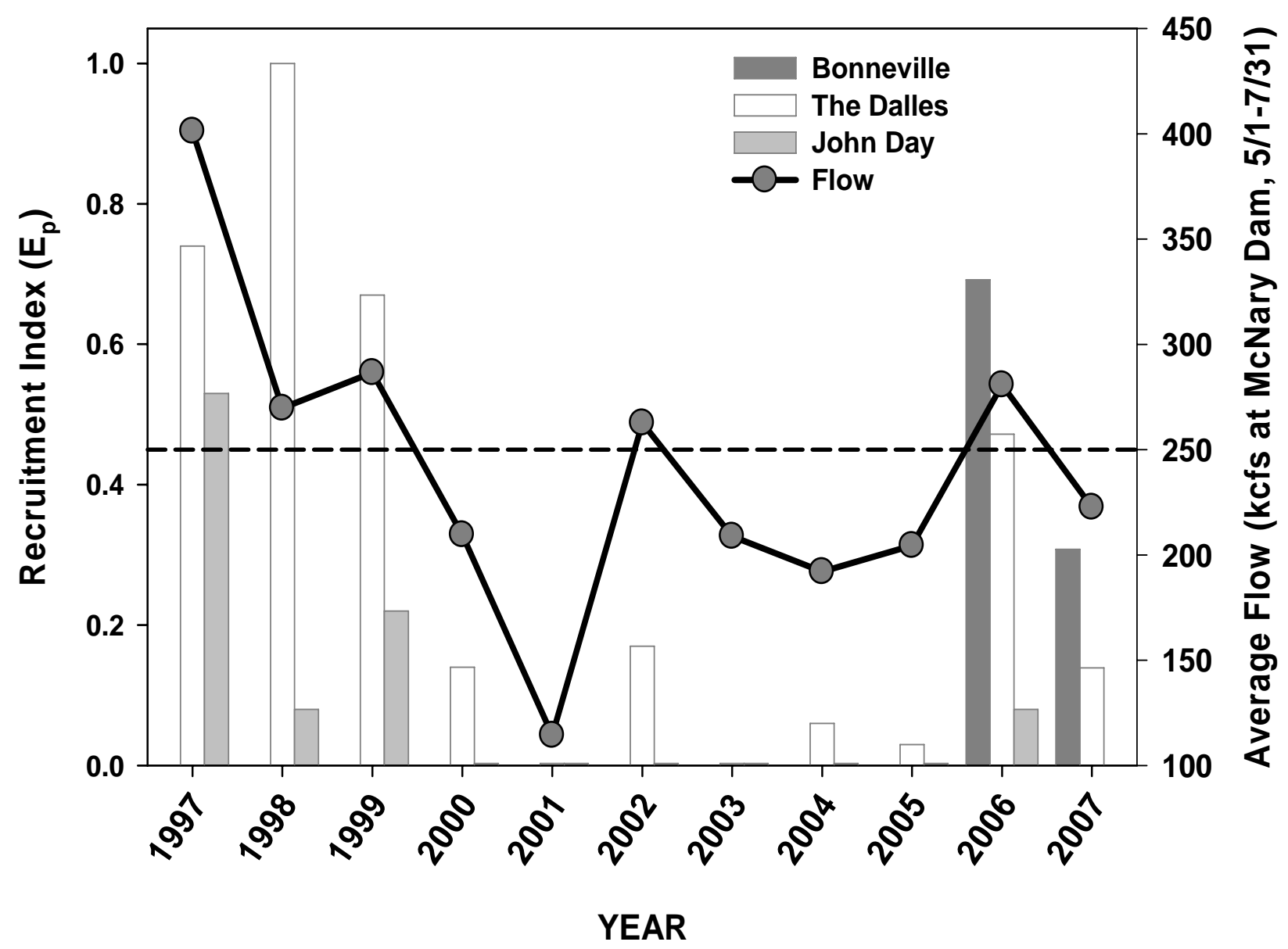

Figure A-12. Recruitment index ( $\mathrm{E}_{\mathrm{p}}$; proportion of sets capturing one or more age- 0 fish) for white sturgeon in Bonneville, The Dalles, and John Day reservoirs, and average daily flow at McNary Dam (May-July). Index values in The Dalles and John Day reservoirs are based on data from standardized gill net efforts initiated in 1997. Gill net efforts to assess recruitment in Bonneville Reservoir began in 2006. The dashed horizontal line indicates the recommended minimum flow to provide adequate spawning habitat in all three reservoirs. 


\section{PLANS FOR NEXT YEAR}

A stock assessment survey will be conducted in The Dalles Reservoir in 2008 (Table A14). We will assess the age and length structure of the white sturgeon population in The Dalles Reservoir as well as estimate the abundance of white sturgeon $\geq 54 \mathrm{~cm}$ FL. We will continue to refine existing methods for describing growth of white sturgeon in Zone 6 reservoirs using information obtained from PIT-tag recoveries during stock assessment surveys.

In 2008, we will also assess white sturgeon recruitment to age-0 in Bonneville, The Dalles, John Day, and McNary reservoirs (Table A-13).

Creel surveys will continue in 2008 (Table A-13). We will assist WDFW with creel sampling in Bonneville and John Day Reservoirs to assess recreational harvest rates of white sturgeon.

Table A-13. Approximate timing of major tasks for the 2007-2008 project year.

\begin{tabular}{|c|c|c|c|c|c|c|c|c|c|c|c|c|}
\hline \multicolumn{8}{|c|}{2008} & \multicolumn{5}{|c|}{2009} \\
\hline Task & A & M & $\mathrm{J}$ & $\mathrm{J}$ & A & $\mathrm{S}$ & $\mathrm{O}$ & $\mathrm{N}$ & $\mathrm{D}$ & $\mathrm{J}$ & $\mathrm{F}$ & M \\
\hline $\begin{array}{l}\text { Stock Assessment (John } \\
\text { Day Reservoir) }\end{array}$ & & & $X$ & $\mathrm{X}$ & $X$ & & & & & & & \\
\hline $\begin{array}{l}\text { Age-0 Indexing } \\
\text { (Bonneville, The Dalles, } \\
\text { John Day, and McNary } \\
\text { Reservoirs) }\end{array}$ & & & & & & & $X$ & $X$ & & & & \\
\hline $\begin{array}{l}\text { Creel (Bonneville and } \\
\text { The Dalles Reservoirs) }\end{array}$ & $\mathrm{X}$ & $\mathrm{X}$ & $\mathrm{X}$ & $X$ & $X$ & & & & & $\mathrm{X}$ & $X$ & $X$ \\
\hline
\end{tabular}




\section{ACKNOWLEDGMENTS}

We would like to thank the following people who helped collect the data used in this report. ODFW: Bonnie Cunningham, Ruth Farr, Wendy Martin, Martyne Reesman, Londi Tomaro, and Wayne van der Naald; WDFW: Cameron Black, Brad Cady, Dennis Gilliland, Blake Hamalainen, Olaf Langness, Tony Ordway, and Greg Smith; CRITFC: Charles Gardee, James Kiona, and Paul Kuneki.

We would also like to acknowledge Ruth Farr for her lead work ageing the pectoral fin spine samples, and Blaine Parker for his help coordinating our cooperative sampling program with CRITFC.

\section{REFERENCES}

Beamesderfer, R.C.P., J.C. Elliott, and C.A. Foster. 1989. Report A. 1) Description of the life history and population dynamics of subadult and adult white sturgeon in the Columbia River between Bonneville and McNary dams, and 2) Evaluation of the need and identification of potential methods for protecting, mitigating, and enhancing white sturgeon populations in the Columbia River downstream from McNary Dam. Pages 5 to 52 in A.A. Nigro, editor. Status and habitat requirements of white sturgeon populations in the Columbia River downstream from McNary Dam. Annual Progress Report to Bonneville Power Administration, Portland, Oregon.

Beamesderfer, R.C.P. 1993. A Standard Weight $\left(\mathrm{W}_{\mathrm{s}}\right)$ Equation for White Sturgeon. California Fish and Game 79(2):63-69.

Beamesderfer, R.C.P., T.A. Rien, and A.A. Nigro. 1995. Differences in the dynamics and potential production of impounded and unimpounded white sturgeon populations in the lower Columbia River. Transactions of the American Fisheries Society 124:857-872.

Bertalanffy, L. von. 1938. A quantitative theory of organic growth (inquiries on growth laws II). Human Biology 10(2):181-213.

Borchers, D.L., S.T. Buckland, and W. Zucchini. 2002. Estimating animal abundance: Closed populations. Statistics for biology and health. London: Springer-Verlag.

Chapman, C.G. and M. Hughes-Weaver. 2007. Report A. Evaluate the success of developing and implementing a management plan for enhancing production of white sturgeon in reservoirs between Bonneville and McNary dams. Pages 7 to 49 in T.A. Rien, editor. White sturgeon mitigation and restoration in the Columbia and Snake rivers upstream from Bonneville Dam. Annual Progress Report to Bonneville Power Administration, Portland, Oregon. 
Chapman, D.G. 1952. Inverse multiple and sequential sample censuses. Biometrics 8:286-306.

Chapman, D.G. 1954. The estimation of biological populations. Ann. Mathemat. Stat. 25:1-15.

Counihan, T.D., A.I. Miller, and M.J. Parsley. 1999. Indexing the Relative Abundance of Age-0 White Sturgeons in an Impoundment of the Lower Columbia River from Highly Skewed Trawling Data. North American Journal of Fisheries Management 19:520-529.

Craig, J.A., and R.L. Hacker. 1940. The history and development of the fisheries of the Columbia River. U.S. Bureau of Fisheries Bulletin 49(32):132-216.

Elliott, J.C., and R.C. Beamesderfer. 1990. Comparison of efficiency and selectivity of three gears used to sample white sturgeon in a Columbia River reservoir. California Fish and Game 76:174-180.

Hughes M.L., J.C. Kern, and T.A. Rien. 2006. Report A. Evaluate the success of developing and implementing a management plan for enhancing production of white sturgeon in reservoirs between Bonneville and McNary dams. Pages 6 to 45 in T.A. Rien, editor. White sturgeon mitigation and restoration in the Columbia and Snake rivers upstream from Bonneville Dam. Annual Progress Report to Bonneville Power Administration, Portland, Oregon.

Kern, J.C., T.A. Rien, and R.A. Farr. 2001. Report A. Evaluate the success of developing and implementing a management plan for white sturgeon in reservoirs between Bonneville and McNary dams in enhancing production. Pages 5 to 42 in D.L. Ward, editor. Status and habitat requirements of white sturgeon populations in the Columbia River downstream from McNary Dam. Annual Progress Report to Bonneville Power Administration, Portland, Oregon.

Kern, J.C., M.L. Hughes, and T.A. Rien. 2003. Report A. Evaluate the success of developing and implementing a management plan for white sturgeon in reservoirs between Bonneville and McNary dams in enhancing production. Pages 5 to 68 in D.L. Ward, editor. Status and habitat requirements of white sturgeon populations in the Columbia River downstream from McNary Dam. Annual Progress Report to Bonneville Power Administration, Portland, Oregon.

McCabe, G.T., Jr., and C.A. Tracy. 1994. Spawning and early life history of white sturgeon, Acipenser transmontanus, in the lower Columbia River. Fishery Bulletin 92:760-772.

North, J.A., T.A. Rien, and R.A. Farr. 1998. Report A. Evaluate the success of developing and implementing a management plan for white sturgeon in reservoirs between Bonneville and McNary dams in enhancing production. Pages 6 to 33 in D.L. Ward, editor. Status and habitat requirements of white sturgeon populations in the Columbia River downstream from McNary Dam. Annual Progress Report to Bonneville Power Administration, Portland, Oregon. 
Parsley, M.J., D.G. Gallion, K.M. Kappenman, and P. Kofoot. 2001. Report C. Describe reproduction and early life history characteristics of white sturgeon populations in the Columbia River between Bonneville and Priest Rapids dams. In D.L. Ward, editor. Status and habitat requirements of white sturgeon populations in the Columbia River downstream from McNary Dam. Annual Progress Report to Bonneville Power Administration, Portland, Oregon.

Parsley, M.J. 1993. Discharges and spawning habitat. 8 June 1993 USFWS memo to Sturgeon Project Cooperators. 9 pp. In Beiningen, K.T. 1995. Effects of mitigative measures on productivity of white sturgeon populations in the Columbia River downstream from McNary Dam, and Status and habitat requirements of white sturgeon populations in the Columbia and Snake rivers upstream from McNary Dam. Annual Progress Report to Bonneville Power Administration, Portland, Oregon.

Parsley, M.J., L.G. Beckman \& G.T. McCabe, Jr. 1993a. Spawning and rearing habitat use by white sturgeons in the Columbia River downstream from McNary Dam. Trans. Amer. Fish. Soc. 122: 217-227.

Parsley, M.J. and L.G. Beckman. 1994. White sturgeon spawning and rearing habitat in the lower Columbia River. North American Journal of Fisheries Management 14:812-827.

Ricker, W.E. 1975. Computation and interpretation of biological statistics of fish populations. Bull. Fish. Res. Board Can. No. 191, 382 p.

Rien, T.A., and R.C.P. Beamesderfer. 1994. Accuracy of precision of white sturgeon age estimates from pectoral fin rays. Transactions of the American Fisheries Society 123: 255-265.

SAS (Statistical Analysis Systems). 2003. SAS/STAT User's Guide, Version 9.1 Edition. SAS Institute, Cary, North Carolina.

Schnabel, Z.E. 1938. The estimation of the total fish population of a lake. Am. Mathemat. Mon. 45:348-352.

Scott, W.B. and E.J. Crossman. 1973. Freshwater fishes of Canada. Bull. Fish. Res. Board Can. 184. 966 pp.

Tracy, C.A. 1993. Status of white sturgeon resources in the main stem Columbia River. Final Report. Dingell/Johnson-Wallop/Breaux Project F-77-R, Washington Department of Fisheries, Battleground. 16 pp. 


\section{APPENDIX}

Table A-14. Catch of non-target species during sampling for age-0 sturgeon in Bonneville, The Dalles, John Day, and McNary reservoirs, October - November 2006. Disposition: 1=alive and released, $2=$ sacrificed, $3=$ dead or dying at capture.

\begin{tabular}{|c|c|c|c|c|c|c|c|c|c|c|c|c|c|c|}
\hline \multirow[b]{2}{*}{ Species } & \multicolumn{4}{|c|}{$\begin{array}{l}\text { Bonneville } \\
\text { Disposition }\end{array}$} & \multicolumn{3}{|c|}{$\begin{array}{l}\text { The Dalles } \\
\text { Disposition }\end{array}$} & \multicolumn{3}{|c|}{$\begin{array}{l}\text { John Day } \\
\text { Disposition }\end{array}$} & \multicolumn{3}{|c|}{$\begin{array}{c}\text { McNary } \\
\text { Disposition }\end{array}$} & \multirow[b]{2}{*}{ Total } \\
\hline & 1 & 2 & 3 & All & 1 & 3 & All & 1 & 3 & All & 1 & 3 & All & \\
\hline $\begin{array}{l}\text { American Shad } \\
\text { Alosa sapidissima }\end{array}$ & & 1 & 4 & 5 & & 2 & 2 & & 7 & 7 & & 5 & 5 & 19 \\
\hline $\begin{array}{l}\text { Bridgelip Sucker } \\
\text { Catostomus columbianus }\end{array}$ & & & & & 1 & 1 & 2 & & & & & 1 & 1 & 3 \\
\hline $\begin{array}{l}\text { Carp } \\
\text { Cyprinus carpio }\end{array}$ & & & & & & & & 1 & & 1 & & & & 1 \\
\hline $\begin{array}{l}\text { Channel Catfish } \\
\text { Ictalurus punctatus }\end{array}$ & & & & & 2 & & 2 & 16 & 2 & 18 & 36 & 17 & 53 & 73 \\
\hline $\begin{array}{l}\text { Chiselmouth } \\
\text { Acrocheilus alutaceus }\end{array}$ & & & 1 & 1 & & & & 3 & 1 & 4 & 15 & 11 & 26 & 31 \\
\hline $\begin{array}{l}\text { Coho } \\
\text { Oncorhynchus kisutch }\end{array}$ & & & & & & & & & & & & 1 & 1 & 1 \\
\hline $\begin{array}{l}\text { Crappie } \\
\text { (Genus: Pomoxis) }\end{array}$ & & & & & & & & 2 & & 2 & & & & 2 \\
\hline $\begin{array}{l}\text { Crayfish } \\
\text { (Genus: Pacifastacus) }\end{array}$ & & & & & & & & 5 & & 5 & 1 & & 1 & 6 \\
\hline $\begin{array}{l}\text { Largemouth Bass } \\
\text { Micropterus salmoides }\end{array}$ & & & & & & & & & & & & 1 & 1 & 1 \\
\hline $\begin{array}{l}\text { Largescale Sucker } \\
\text { Catostomus macrocheilus }\end{array}$ & & & 1 & 1 & 4 & 3 & 7 & 7 & 3 & 10 & 9 & 15 & 24 & 42 \\
\hline $\begin{array}{l}\text { Mountain Whitefish } \\
\text { Prosopium williamsoni }\end{array}$ & & & & & & 1 & 1 & & & & & 1 & 1 & 2 \\
\hline $\begin{array}{l}\text { Northern Pikeminnow } \\
\text { Ptychocheilus }\end{array}$ & 9 & & 19 & 28 & 7 & 15 & 22 & 6 & 9 & 15 & 13 & 19 & 32 & 97 \\
\hline $\begin{array}{l}\text { Peamouth Chub } \\
\text { Mylocheilus caurinus }\end{array}$ & 12 & & 21 & 33 & 9 & 10 & 19 & 1 & 1 & 2 & 3 & 14 & 17 & 71 \\
\hline $\begin{array}{l}\text { Sculpin } \\
\text { (Genus: Cottus) }\end{array}$ & 1 & & & 1 & 1 & 1 & 2 & 1 & & 1 & 2 & & 2 & 6 \\
\hline $\begin{array}{l}\text { Smallmouth Bass } \\
\text { Micropterus dolomieu }\end{array}$ & 2 & & 1 & 3 & 1 & & 1 & 1 & & 1 & 2 & 1 & 3 & 8 \\
\hline $\begin{array}{l}\text { Steelhead } \\
\text { Oncorhynchus mykiss }\end{array}$ & & & & & & & & 1 & & 1 & & & & 1 \\
\hline $\begin{array}{l}\text { Walleye } \\
\text { Sander vitreus }\end{array}$ & 1 & & 2 & 3 & 1 & 6 & 7 & 3 & 6 & 9 & 1 & 7 & 8 & 27 \\
\hline $\begin{array}{l}\text { Yellow Perch } \\
\text { Perca flavescens }\end{array}$ & & & 1 & 1 & 4 & 10 & 14 & 19 & 29 & 48 & 18 & 34 & 52 & 115 \\
\hline Total & 25 & 1 & 50 & 76 & 30 & 49 & 79 & 66 & 58 & 124 & 100 & 127 & 227 & 506 \\
\hline
\end{tabular}


Table A-15. Abundance estimates for Zone 6 reservoirs and the Hanford Reach of McNary Reservoir, 1987 - 2007.

\begin{tabular}{|c|c|c|c|c|c|c|c|c|c|}
\hline \multirow[b]{2}{*}{ Year } & \multirow{2}{*}{$\begin{array}{c}\text { 30-72 inch total length } \\
\mathrm{N}(95 \% \mathrm{CI})\end{array}$} & \multicolumn{6}{|c|}{ Number of fish by total length interval (inches) } & \multirow{2}{*}{$\begin{array}{l}\text { Number/ } \\
\text { Acre }^{\mathrm{a}}\end{array}$} & \multirow{2}{*}{$\begin{array}{l}\text { Pounds/ } \\
\text { Acre }^{\text {c }}\end{array}$} \\
\hline & & $24-36$ & $36-48$ & $48-60$ & $60-72$ & $72+$ & Sum & & \\
\hline & \multicolumn{9}{|c|}{ Hanford Reach and McNarv Reservoir } \\
\hline \multirow[t]{2}{*}{1995} & $5.234(3.782-9.086)$ & 900 & 2.700 & & & 1.250 & 8.250 & 0.2 & 8 \\
\hline & \multicolumn{9}{|c|}{ Bonneville Reservoir } \\
\hline 1989 & $35.400(27.500-45.400)$ & 32.900 & 16.700 & 1.000 & 200 & 600 & 51.400 & 2.5 & 27 \\
\hline 1994 & $35,200(24,800-66,000)$ & 31,300 & 18,300 & 1,300 & 200 & 900 & 52,000 & 2.5 & -- \\
\hline 1999 & $85.400^{\mathrm{b}}$ & 82.400 & 41.800 & 3.200 & 600 & 400 & 128.400 & 6.2 & 59 \\
\hline 2003 & $74,000^{\mathrm{b}}$ & 84,500 & 33,000 & 1,100 & 120 & 780 & 119,500 & 5.7 & 46 \\
\hline \multirow[t]{2}{*}{2006} & 113,300 & 159,000 & 45,200 & 590 & 350 & 240 & 205,400 & 9.9 & 67 \\
\hline & \multicolumn{9}{|c|}{ The Dalles Reservoir } \\
\hline 1987 & $23,600(15,700-33,600)$ & 7,800 & 11,000 & 6,100 & 1,800 & 1,000 & 27,700 & 2.5 & 73 \\
\hline 1988 & $9.000(7.300-11.000)$ & 4.200 & 4.300 & 1.500 & 500 & 800 & 11.300 & 1.0 & 32 \\
\hline 1994 & $9,700(7,500-14,000)$ & 5,800 & 5,700 & 800 & $<50$ & 300 & 12,600 & 1.1 & -- \\
\hline 2002 & $33.000(26.200-42.000)$ & 82.900 & 13.500 & 5.900 & 1.200 & 800 & 104.300 & 9.4 & 87 \\
\hline \multirow[t]{2}{*}{2005} & $45,700(37,000-56,300)$ & 90,600 & 10,200 & 1,100 & 500 & 400 & 102,800 & 9.3 & 69 \\
\hline & \multicolumn{9}{|c|}{ John Dav Reservoir } \\
\hline 1990 & $3,900(2,300-6,100)$ & 16,600 & 1,700 & 400 & 100 & 500 & 19,300 & 0.4 & 3 \\
\hline 1996 & $27.100(23.800-30.800)$ & 5.800 & 19.700 & 4.050 & 350 & 700 & 30.600 & 0.6 & 11 \\
\hline 2001 & $19.600^{\mathrm{b}}$ & 14,900 & 12,800 & 1,100 & 300 & 900 & 30,000 & 0.6 & 9 \\
\hline 2004 & $30.000^{\mathrm{b}}$ & 30.200 & 11.500 & 1.100 & 170 & 470 & 43.500 & 0.8 & 9 \\
\hline 2007 & $39,020^{\mathrm{b}}$ & 17,834 & 21,793 & 1,587 & 529 & 841 & 42,584 & 0.8 & 10 \\
\hline
\end{tabular}

${ }^{\mathrm{a}}$ Hanford Reach and McNary Reservoir $=45,500$ acres; Bonneville Reservoir = 20,800 acres; The Dalles Reservoir $=11,100$ acres; John Day Reservoir $=51,900$ acres.

${ }^{\mathrm{b}}$ Confidence intervals for these estimates are not provided because they are derived from expansion, not directly calculated from mark-recapture data.

${ }^{\mathrm{c}}$ Total poundage is estimated by multiplying total abundance $(42,589)$ by median weight $(5.5 \mathrm{~kg}$ or $12.13 \mathrm{lbs})$ of sturgeon caught with setlines in sampling periods 2 and 3. 


\title{
WHITE STURGEON MITIGATION AND RESTORATION IN THE COLUMBIA AND SNAKE RIVERS UPSTREAM FROM BONNEVILLE DAM
}

\section{ANNUAL PROGRESS REPORT}

APRIL 2007 - MARCH 2008

\section{REPORT B}

Evaluate the success of developing and implementing a management plan to enhance production of white sturgeon in reservoirs between Bonneville and McNary dams

This report includes: Progress on implementing the fisheries management component of the white sturgeon management plan for the Columbia River between Bonneville and McNary dams including results of surveying 2007 sport and commercial white sturgeon fisheries.

Prepared by:

Olaf P. Langness

Dennis R. Gilliland

Brad J. Cady

Brad W. James

\author{
Washington Department of Fish and Wildlife \\ Southwest Region \\ 2108 Grand Boulevard \\ Vancouver, Washington 98661
}

January 15, 2009 


\section{TABLE OF CONTENTS}

ACKNOWLEDGMENTS

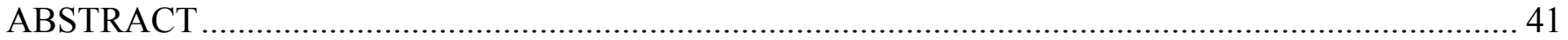

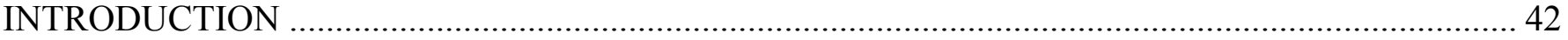

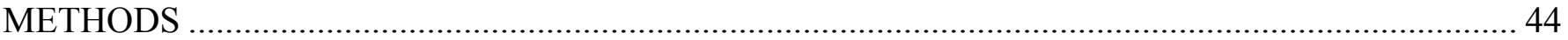

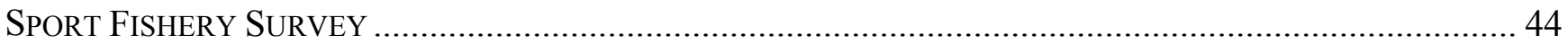

TREATY INDIAN COMMERCIAL AND SUBSISTENCE HARVEST ........................................................ 45

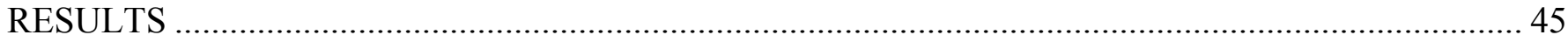

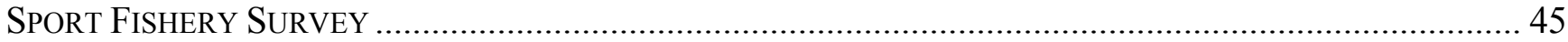

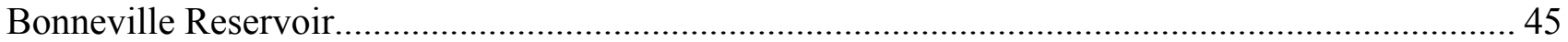

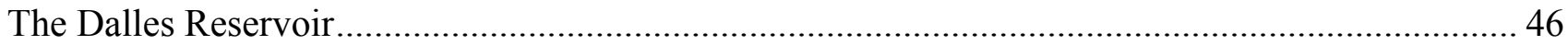

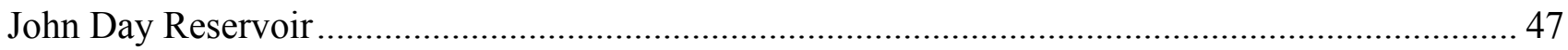

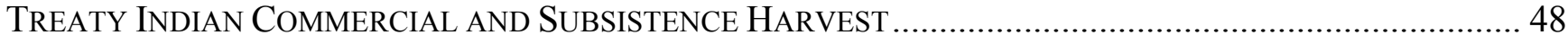

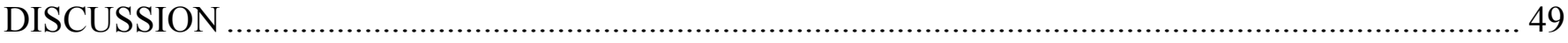

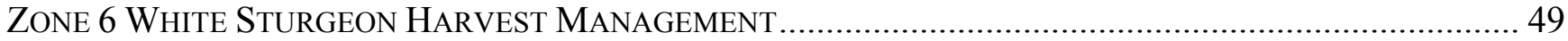

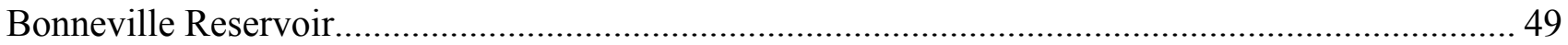

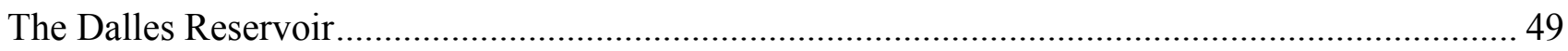

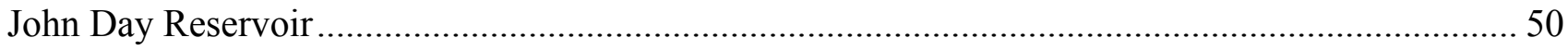

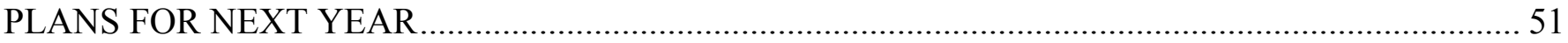

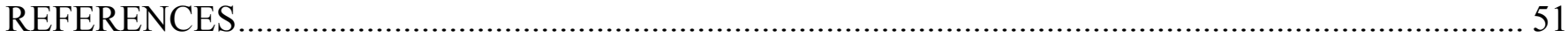




\section{ACKNOWLEDGMENTS}

We wish to thank our field crews who conducted the angler surveys, and young-of-year white sturgeon recruitment indexing: WDFW staff - Greg Smith, Greg Robertson, Shawna Hone, Pat Kaelber, and Dawn Lucas; ODFW staff - Wendy Martin, Bonnie Cunningham, and Michele Weaver. We wish to also thank Rick Heitz, Bonnie Jackman, and Kelly Jenkins of PSMFC, Doug Case of ODFW, and Lee Hoines of WDFW for their work on commercial landing data; and Roger Dick, Jr., Chuck Gardee, and

James Kiona of the Yakama Nation for their work on commercial, ceremonial and subsistence landing data. 


\begin{abstract}
The Washington and Oregon Departments of Fish and Wildlife conducted a survey of the 2007 sport fishery on the Columbia River from Bonneville Dam upstream to McNary Dam (Zone 6 management unit) to estimate white sturgeon Acipenser transmontanus harvest. The sport fishery was closed to the retention of white sturgeon during July 30 - December 31 in Bonneville Reservoir, with an estimated harvest of 682 fish (97\% of the 2007 guideline). The fishery in The Dalles Reservoir was closed to the retention of white sturgeon during March 29 - December 31, with an estimated harvest of 108 fish (108\% of guideline). The John Day Reservoir was closed to retention during June 11 - December 31 , with an estimated harvest of 249 fish (151\% of guideline).

Treaty Indian commercial fishers landed 285 white sturgeon from Bonneville Reservoir (71\% of the 2007 guideline), 607 from The Dalles Reservoir (110\% of guideline), and 232 from John Day Reservoir (69\% of guideline), during gill net and setline fisheries. The Columbia River Inter-Tribal Fish Commission and the Yakama Indian Nation estimated an additional 161 fish were harvested from the three reservoirs (44 from Bonneville Reservoir, 100 from The Dalles Reservoir, and 17 from John Day Reservoir), during the 2007 subsistence fisheries.
\end{abstract}

The harvest guidelines for 2007 were 700 sport and 400 commercial in Bonneville Reservoir, 100 sport and 550 commercial in The Dalles Reservoir, and 165 sport and 335 commercial in John Day Reservoir. These guidelines were established in 2004 in Bonneville Reservoir, 2006 in The Dalles Reservoir, and 2002 in John Day Reservoir.

A targeted oversize white sturgeon fishery began developing in the late 1990's, especially in John Day Reservoir. In 2006, spawning sanctuaries were established below McNary and John Day dams from May 1 - July 31 to protect white sturgeon broodstock from the growing oversize target fishery. Additional monitoring of anglers, especially during non-retention seasons, and particularly in the upper John Day Reservoir where an oversize target fishery is already established, would aid managers in estimating angler effort and handle of oversize white sturgeon. 


\section{INTRODUCTION}

This annual report describes progress made by the Washington Department of Fish and Wildlife (WDFW) toward completing tasks outlined in the Statement of Work for Bonneville Power Administration Project 198605000, White Sturgeon Mitigation and Restoration in the Columbia and Snake Rivers Upstream from Bonneville Dam. The reporting period is from April 1, 2007 through March 31, 2008, but focuses on work conducted from January 1, 2007 through December 31, 2007.

To address tasks related to the three FY 2007 multi-agency project goals, WDFW worked closely with staff from the Oregon Department of Fish and Wildlife (ODFW), the Columbia River Inter-Tribal Fisheries Commission (CRITFC), and Montana State University (MSU). Specific project goals were to:

Goal 1) Ensure persistence of white sturgeon populations.

Goal 2) Restore and maintain population productivity in impounded reaches to levels similar to that in the un-impounded lower Columbia River mainstem.

Goal 3) Restore and ensure sustainable white sturgeon fisheries.

The WDFW was contracted to work on Tasks 1.1, 1.2, 2.1, 2.2, 3.1, 4.1, 4.4, and 5.1 (described below) during the performance period.

Objective 1 (Fisheries Management and Planning):

Task 1.1. Analyze annual fisheries data. Population assessments and harvest projections for Sturgeon Management Task Force. Includes weekly summaries of observed effort and harvest by boat and bank anglers in each reservoir, monthly estimates of harvest, an annual assessment of recreational angling effort, catch rate, and harvest, and treaty commercial and subsistence fishing effort, harvest rate, and harvest. ODFW and WDFW lead (harvest estimates, harvest projections, creel summary, and monthly recreational harvest estimates); CRITFC assists.

Task 1.2. Data collection - sport fisheries. Daily counts of anglers by type (boat/bank) at standardized times and count locations (accessed by car or pickup) along Bonneville, The Dalles, and John Day reservoirs. Representative angler creel interviews recorded on standardized data sheets. Target interview rate is at least $20 \%$ of participating anglers each week. WDFW leads; ODFW assists.

Objective 2 (Stock Assessments):

Task 2.1. Mark / tag white sturgeon in Zone 6. ODFW lead. WDFW assists in marking 5,0006,000 fish captured in John Day Reservoir by removing a specified pattern of lateral scutes. All fish $70 \mathrm{~cm}$ [fork length (FL)] and larger will be PIT tagged until 3,500 fish are marked. Tagging data sheets and data stored on PIT tag readers are provided to ODFW. 
Task 2.2. Spring / summer stock assessment sampling. Setlining for mark recovery, catch rate, length frequency, and age samples. Up to 6,000 fish may be captured. ODFW sets field schedule and coordinates data compilation. This work is conducted jointly in the field by staff from ODFW, WDFW, and CRITFC. WDFW will provide a fully equipped boat and two field staff for 15 weeks of sampling throughout John Day Reservoir.

Objective 3 (Young-of-year (YOY) sampling):

Task 3.1. YOY gillnetting in Bonneville, The Dalles, John Day, and McNary reservoirs. Data set of gill net effort and white sturgeon catch from approximately 148 net sets (12-40 sites per reservoir, each site sampled three times). White sturgeon fork and total lengths will be measured to the nearest millimeter. Age samples (fin spines) are collected from white sturgeon $<70$-cm fork length. This work is conducted jointly in the field by ODFW, WDFW, and CRITFC staff. As lead agency, ODFW provides one boat, one operator, and one additional staff. WDFW provides one boat, one operator, and one additional staff.

Objective 4 (Miscellaneous BPA-required Work Elements):

Task 4.1. Environmental compliance. Take reported to NOAA Fisheries. Annual permit application submitted. Environmental compliance requirements complete for FY07 work. ODFW and subcontractors collaborate to complete this task.

Task 4.4. Produce annual report. Draft (double-spaced throughout) annual report summarizing research activities conducted from April 1, 2007 through March 31, 2008 on project 1986-050-00 circulated to all cooperating agencies (ODFW, CRITFC) by e-mail, and a list of the most important findings in the report, to be used in the Executive Summary. Final report submitted to ODFW as an Adobe portable document file.

Objective 5 (Sex and maturation status):

Task 5.1. Sex and maturation status sampling. Fully equipped research crew (boat operator and crew member, one research vessel, and sampling equipment). This work is conducted jointly in the field by WDFW and MSU. Raw data and samples supplied to MSU by September 2007. 


\section{METHODS}

\section{Sport Fishery Survey}

The 2007 sport fishery survey was conducted in Bonneville and The Dalles reservoirs, and that portion of the John Day Reservoir between Crow Butte Park at river kilometer (Rkm) 423 (Figure B-1) and McNary Dam at Rkm 470, where fishing is concentrated. Methods were similar to those used annually since 1995 (James et al. 1996) and relied on angling effort distribution data collected during surveys of Bonneville Reservoir from 1988 to 1990, The Dalles Reservoir from 1987 to 1989, and John Day Reservoir from 1989 to 1991 (Hale and James 1993). Sampling (effort accounting and angler interviews) was conducted by WDFW and ODFW (WDFW having lead responsibility for this task).

The survey was limited to legal angling hours for white sturgeon (one hour before sunrise to one hour after sunset). Estimates in this report of angling effort and harvest for steelhead Oncorhynchus mykiss, walleye Sander vitreus, smallmouth bass Micropterus dolomieu, largemouth bass M. salmoides, and northern pikeminnow Ptychocheilus oregonensis, are considered conservative estimates, because these species can also be harvested at night (steelhead in Washington only).

Angling effort (angler hours) was estimated by counting anglers within representative index areas and expanding those counts to the entire reservoir using an established relationship derived from the 1987 to 1991 aerial counts of anglers within and outside of established index areas (Hale and James, 1993). Thirty-nine indices of angler effort (17 in Bonneville Reservoir, 10 in The Dalles Reservoir, and 12 in John Day Reservoir) were established at popular fishing locations and vantage points in each reservoir, and have remained essentially the same since 1995. One Oregon bank index area (Rkm 163) was moved upriver, and shared by two adjacent locations (Rkm 168 and Rkm 169) in 2000 to account for a shift in Oregon bank angler effort (James et al., 2001). One Washington bank index area (Rkm 168) was dropped in 2005 due to lack of angler use. Counts were made of all bank anglers and sport fishing boats within each index area. Average numbers of anglers per boat were determined from angler interviews. Angling effort within index areas was counted once a day between 1000 and 1300 hours. The proportion of the day's total angling effort was calculated from average daily angling effort distributions derived from prior years' data when systematic counts were made throughout the day.

Harvest estimates for boat anglers were calculated by multiplying the observed catch per hour for boat anglers within a reservoir subsection by the total estimated effort (hours) for boat anglers for that subsection. The one fish daily bag limit (enacted in 1991 for The Dalles and John Day reservoirs and in April 1996 for Bonneville Reservoir) makes it likely that some successful bank anglers leave the river before we can interview them, thus biasing our estimate of harvest per hour of bank angling effort. Boat angler catch per hour of effort is not biased by the one fish daily bag limit since we only interview boat anglers after they complete their trip. To arrive at unbiased estimates of white sturgeon harvest by bank anglers, we calculated reservoir specific ratios of boat angler harvest per unit effort (HPUE) vs. bank angler HPUE for years prior to one fish bag limits (1993-95 for Bonneville Reservoir, 1988-89 for The Dalles Reservoir, and 1989-90 for John Day Reservoir). The boat angler HPUE for 2007 was used to adjust the 2007 bank angling HPUE such that boat HPUE versus bank HPUE matched the pre-one fish

daily limit ratio. Harvest estimates were derived for each angling method (bank/boat), reservoir 
subsection, and weekend/weekday type to account for differential catch and sampling rates. Harvest and angling effort estimates were derived for each week. No sport fishery sampling was conducted in John Day Reservoir for January and February 2007, so harvest estimates for those months were based on historical averages.

\section{Treaty Indian Commercial and Subsistence Harvest}

Numbers of white sturgeon harvested in Zone 6 treaty Indian commercial fisheries were estimated from poundage reported on fish receiving tickets for each gear type and catch area. Poundage of white sturgeon was converted to numbers of fish by dividing the total poundage by an average fish weight obtained during random biological sampling of treaty Indian commercial landings. This approach to derive numbers landed is considered more accurate than just taking numbers from the commercial landing tickets (sales are in pounds and therefore carefully recorded, whereas numbers on the tickets are often just estimated during large deliveries). Landings by reservoir were estimated from the catch area reported on fish receiving tickets. The legal size slot for treaty Indian commercial fisheries was 114-152 cm (45-60 in) total length (TL) in Bonneville Reservoir, and 122-152 cm (48-60 in) TL in The Dalles and John Day reservoirs. Yakama Nation technical staff conducted unstructured interviews of treaty Indian fishers to estimate subsistence harvest of white sturgeon, in each reservoir.

\section{RESULTS}

\section{Sport Fishery Survey}

\section{$\underline{\text { Bonneville Reservoir }}$}

We began our survey of the 2007 sport fishery on January 2, and continued sampling through July 29. State fishery managers closed the fishery to retention of white sturgeon on July 30 based on our inseason projection that harvest would reach the guideline by that date.

Anglers fished an estimated 79,558 hours (14,686 trips) in Bonneville Reservoir during the retention season (Table B-1). Angling effort for white sturgeon comprised $60 \%$ (8,745 trips) of the total estimated effort. The estimated number of angler trips for other target species were as follows: 1,192 (8\%) for anadromous salmonids, 350 (2\%) for American shad Alosa sapidissima, 621 (4\%) for walleye, 1,642 (11\%) for smallmouth and largemouth bass, 1,752 (12\%) for northern pikeminnow, $210(2 \%)$ for other resident fish, and 174 (1\%) for anglers participating in tournaments.

Angler trips for white sturgeon during the 2007 retention season decreased $12 \%$ from the 2006 retention period effort. The 18,489 white sturgeon caught (kept and released; Table B-2) during the 2007 retention season are $31 \%$ less than the 2006 retention period catch. Sub-legal catch decreased by $33 \%$ and oversize catch decreased by $4 \%$ over corresponding 2006 catches. The fishery for white sturgeon encompassed the entire reservoir with slightly more of the angler effort occurring upstream of Hood 
River, Oregon (Rkm 271). Monthly combined boat and bank harvest per angler trip (HPUE) peaked in June at 0.14 fish per trip. Season HPUE averaged 0.06 fish per trip for bank anglers and 0.09 fish per trip for boat anglers targeting white sturgeon (Table B-3). The 1,849 white sturgeon anglers interviewed accounted for $18 \%$ of the estimated bank effort (angler hours) and 11\% of the estimated boat effort for white sturgeon (Tables B-1 and B-4).

Anglers released $24 \%$ of the legal-size catch during the retention period, due in part to the daily bag limit regulation, which allowed retention of only one fish per day. The percentage of sub-legal $(<107$ cm TL; $<42$ in TL), legal (107-152 cm TL; 42-60 in TL; both kept and released), and oversize $(>152 \mathrm{~cm}$ TL; $>60$ in TL) white sturgeon in the reported catch was $91 \%, 5 \%$, and $4 \%$, respectively (Table B-4). This distribution of catch by size is similar to the distribution in 2006, with slight gains in the oversize and legal categories and a corresponding decrease in the sub-legal category. The length distribution of the sampled harvest ranged from $94-138 \mathrm{~cm}$ fork length (FL), with $82 \%$ of the harvest occurring in the bottom $15 \mathrm{~cm}$ of the legal size range $(<112 \mathrm{~cm}$ FL; 107-121 cm TL; Table B-5). Boat anglers' HPUE of 96-137 cm FL (approximately equivalent to 42-60 in TL) fish decreased from 2006 to the lowest HPUE since the creel survey began in 1987. Bank anglers' HPUE more than doubled to the highest since 2003. Combined boat and bank HPUE increased, slightly exceeding each of the last 2 years (Table B-6), but was still the third lowest on record. The estimated sport harvest (682) was $97 \%$ of the 700 white sturgeon guideline (Table B-7), and has averaged 97\% of the guideline from 1998-2007.

Oversize catch in Bonneville Reservoir since 1995 has ranged from $0.1 \%$ to $5.7 \%$ of total catch. The 895 oversize fish caught in 2007 represent $4.8 \%$ of total catch in 2007, and the second highest percent of total catch on record since 1995 (Table B-8; Figure B-2). Sturgeon-targeted angler trips for June and July were each nearly double the prior 5-month average, and accounted for over $90 \%$ of oversize catch.

\section{The Dalles Reservoir}

We began our survey of the 2007 sport fishery on January 2 and continued sampling through March 28. State fishery managers closed the fishery to retention of white sturgeon on March 29 based on our in-season projection that harvest would reach the guideline by that date.

Anglers fished an estimated 23,020 hours (3,818 trips) in The Dalles Reservoir during the retention season (Table B-1). Angling effort for white sturgeon comprised 45\% (1,723 trips) of the total estimated trips. The estimated number of angler trips for other target species were as follows: $366(9 \%)$ for anadromous salmonids, $0(0 \%)$ for American shad, 1,679 $(44 \%)$ for walleye, $11(<1 \%)$ for smallmouth and largemouth bass, $0(0 \%)$ for northern pikeminnow, $39(1 \%)$ for other resident fish, and $0(0 \%)$ for anglers participating in tournaments.

Angler trips for white sturgeon during the 2007 retention period decreased $30 \%$ from the 2006 retention period effort. The 1,352 white sturgeon caught (kept and released; Table B-2) during the 2007 retention season are 15\% less than the 2006 retention period catch. The sport fishery effort for white sturgeon was focused primarily from the John Day Dam tailrace downstream to Miller Island (Rkm 327). Monthly combined boat and bank HPUE peaked in January at 0.09 fish per trip. Season HPUE averaged 0.02 for bank anglers and 0.13 for boat anglers targeting white sturgeon (Table B-3). The 552 white 
sturgeon anglers interviewed accounted for $20 \%$ of the estimated bank effort (angler hours) and $24 \%$ of the estimated boat effort for white sturgeon (Tables B-1 and B-4).

Anglers released $4 \%$ of the legal-size catch during the retention period. The percentage of sublegal ( $<122 \mathrm{~cm} \mathrm{TL} ;<48$ in TL), legal (122-152 cm TL; 48-60 in TL), and oversize ( $>152 \mathrm{~cm}$ TL; $>60$ in TL) white sturgeon in the sampled catch was $88 \%, 8 \%$, and $4 \%$, respectively (Table B-4). This distribution of catch by size is similar to the distribution in 2006, with slight gains in the oversize and legal categories and a corresponding decrease in the sub-legal category. The length distribution of the sampled harvest ranged from 107-136 cm FL, with 74\% of the harvest occurring in the bottom $15 \mathrm{~cm}$ range of the legal size slot $(<126 \mathrm{~cm}$ FL; 122-137 cm TL; Table B-5). Boat anglers' HPUE of 110-137 cm FL (approximately equivalent to 48-60 in TL) fish increased 64\% from 2006 to the highest since 2002. Bank anglers' HPUE more than doubled from 2006, but matched 2005 for the second lowest since 1987. Combined boat and bank HPUE was the third lowest since 1997 (Table B-6). The estimated harvest (108) was $108 \%$ of the 100 white sturgeon guideline (Table B-7). Sport harvest has averaged $110 \%$ of the guideline from $1998-2007$.

Oversize catch in The Dalles Reservoir since 1995 has ranged from $0.5 \%$ to $4.5 \%$ of total catch. The 49 oversize fish caught in 2007 represent $3.6 \%$ of total catch, and a $23 \%$ increase from the 2006 oversize catch (Table B-8; Figure B-2).

\section{$\underline{\text { John Day Reservoir }}$}

The fishery opened January 1, 2007 and was closed to retention of white sturgeon on June 11. We conducted our survey of the sport fishery in John Day Reservoir from March 1 through June 10. To save project costs, creel sampling was not conducted in January and February. Since effort and harvest are typically low during those months, it was deemed appropriate to base harvest estimates on historical averages.

Anglers fished an estimated 96,400 hours (17,064 trips) in John Day Reservoir during the retention season (Table B-1). Angling effort for white sturgeon comprised 32\% (5,487 trips) of the total estimated trips. The estimated number of angler trips for other target species were as follows: 754 (4\%) for anadromous salmonids, $48(<1 \%)$ for American shad, 6,412 (38\%) for walleye, 3,411 (20\%) for smallmouth and largemouth bass, $48(<1 \%)$ for northern pikeminnow, $718(4 \%)$ for other resident fish, and $186(1 \%)$ for tournament anglers.

Angler trips for white sturgeon during the 2007 retention season were up $15 \%$ from the 2006 retention period effort. The 5,759 white sturgeon caught (kept and released; Table B-2) during the 2007 retention season are $22 \%$ more than the 2006 retention period catch. Anglers concentrated their effort for white sturgeon from McNary Dam downstream past Irrigon, Oregon to Rkm 449. Monthly combined boat and bank HPUE peaked in June at 0.09 fish per trip. Season HPUE averaged 0.02 for bank anglers and 0.05 for boat anglers targeting white sturgeon (Table B-3). The 1,100 white sturgeon anglers interviewed accounted for $18 \%$ of the estimated bank effort (angler hours) and $16 \%$ of the estimated boat effort for white sturgeon (Tables B-1 and B-4). 
Anglers released $14 \%$ of the legal-size catch during the retention period (Table B-4). The percentage of sub-legal ( $<122 \mathrm{~cm} \mathrm{TL} ;<48$ in TL), legal $(122-152 \mathrm{~cm}$ TL, 48-60 in TL), and oversize $(>152 \mathrm{~cm} \mathrm{TL},>60$ in TL) white sturgeon in the reported catch was $91 \%, 5 \%$, and $4 \%$, respectively (Table B-4). This length distribution is similar to the distribution in 2006, with slight gains in the legal and oversize categories and a corresponding decrease in the sub-legal category. The length distribution of the sampled harvest ranged from 108-139 cm FL, with 78\% of the harvest occurring in the bottom $15 \mathrm{~cm}$ range of the legal size slot ( $<126 \mathrm{~cm}$ FL; 122-137 cm TL; Table B-5). Boat anglers' HPUE of 110-137 cm FL (approximately equivalent to 48-60 in TL) fish increased from 2006 to the highest since 1997. Bank anglers' HPUE dropped by $66 \%$ from the 2006 value. Combined boat and bank HPUE was still the second highest on record, nearly matching the high in 1997 (Table B-6). The estimated harvest (249) was $151 \%$ of the 165 white sturgeon guideline (Table B-7). Sport harvest has averaged $99 \%$ of the guideline from 1998-2007

Oversize catch in John Day Reservoir since 1995 has ranged from 1.3\% to $12.8 \%$ of total catch. The 169 oversize fish caught in 2007 represent 2.9\% of total catch, a 70\% increase from the 2006 oversize catch, but much better than the $9 \%$ of total catch average from 1997 through 2005 (Table B-8; Figure B-2). Only 29\% of the sturgeon-targeted angler trips occurred during the six weeks of the spawning sanctuary closure, but they accounted for $47 \%$ of the oversize catch.

\section{Treaty Indian Commercial and Subsistence Harvest}

The 2007 treaty Indian commercial harvest estimates for Zone 6 were 285 white sturgeon from Bonneville Reservoir, 607 white sturgeon from The Dalles Reservoir, and 232 white sturgeon from John Day Reservoir (Table B-7). Six fish (5 from Bonneville Reservoir, 1 from The Dalles Reservoir) were reported from the January setline season. The Dalles Reservoir reached its 2007 commercial harvest guideline and was closed on March 9. The harvest in both Bonneville and John Day reservoirs was still below guideline following the winter gill net fishery. A fall setline fishery (August 1 - 18) was opened for John Day Reservoir. Total harvest estimates were $71 \%, 110 \%$, and $69 \%$ of guideline for Bonneville, The Dalles, and John Day reservoirs, respectively. The treaty Indian Zone 6 subsistence white sturgeon harvest estimated by CRITFC and YN was 161 fish (Table B-7): 44 from Bonneville Reservoir; 100 from The Dalles Reservoir; and, 17 from John Day Reservoir. Forty-six percent ( 74 fish) of the subsistence harvest occurred during the winter gillnet fishery, with $2 \%(4), 22 \%(35)$, and $30 \%$ (48) in the spring, summer and fall fisheries, respectively (Roger Dick, YN, personal communication). 


\title{
DISCUSSION
}

\section{Zone 6 White Sturgeon Harvest Management}

\author{
$\underline{\text { Bonneville Reservoir }}$
}

Since the 1,520 fish recreational guideline began in 1997, HPUE for both boat and bank anglers has declined, while their relative effort has fluctuated. From 1988 - 2002 bank effort generally exceeded boat effort. Beginning in 2003 the majority of effort shifted to boat angling. Combined sport and commercial harvest as compared to the guideline trended downward from 1997 through 2003, stabilized for two years when the guidelines were lowered in 2004, dropped again in 2006, then recovered slightly in 2007. The sport season was one week longer than in 2006, with a $12 \%$ decrease in combined boat and bank effort for white sturgeon. Boat HPUE has trended generally downward since 1995, with 2007 being the lowest on record. Bank HPUE more than doubled from 2006, but was still the third lowest on record. These trends may indicate that removal from the legal size class, either by harvest or escapement, is exceeding recruitment from the sub-legal size class. In the sport fishery, the portion of fish harvested within the smallest $15 \mathrm{~cm}$ of the legal-size slot (107 - $122 \mathrm{~cm} \mathrm{TL}$ ) was 82\% in 2007, matching the 20012006 average.

Following a substantial increase in 2001, the percentage of oversize fish in the estimated white sturgeon sport catch declined through 2005, but has substantially increased in each of the last two years (Figure B-2). The sturgeon-targeted angler trips increased substantially for both June and July, and $90 \%$ of the oversize catch occurred in those two months. These observations suggest that sturgeon anglers may be shifting to Bonneville Reservoir in response to the spawning sanctuary closure in John Day Reservoir and the closed retention fishery in The Dalles Reservoir. At some point it may be necessary to implement a spawning sanctuary in Bonneville Reservoir also.

Tribal commercial harvest of 285 white sturgeon was up from 2006, but was still well below the 400 fish guideline. Commercial harvest dropped substantially in 2002, and has continued to trend downward. Subsistence fisheries harvested an additional 44 fish, and shows a similar trend beginning in 2003.

\section{The Dalles Reservoir}

Abundance estimates from the 1997 stock assessment in The Dalles Reservoir (North et al., 1999), supported an increase of the recreational harvest guideline from 200 to 700 fish in 1998. Season lengths between 1998 and 2002 showed a slight increasing trend. Effort fluctuated from 1998 through 2002; however, the HPUE trended down for combined boat and bank angler fisheries. The legal-sized population estimate in the reservoir declined from 8,300 fish in 1997 (North et al. 1999) to 5,900 fish in 2002 (Kern et al, 2004). Subsequently there was a 43\% guideline decrease in 2003. From 2003 through 2005, combined boat and bank angler effort increased slightly, while HPUE continued to trend downward. Those trends, combined with drop in abundance estimates and a shift toward the lower end of the frequency distribution, indicated a need to reduce the guidelines in 2006, resulting in a shorter season $\&$ lower total catch. The proportion of sport harvested white sturgeon in the smallest $15 \mathrm{~cm}$ of the legal- 
size range (122-137 cm TL) increased slightly from 2006, but matched the 2001-2006 average. As in Bonneville Reservoir, the trends may indicate that removal from the legal size class exceeds recruitment from the sub-legal size class.

In 2000, the oversize percentage of total catch increased substantially over the 1995-1999 average, and though fluctuating, has remained near three times that average. The oversize percentage for 2007 was up from 2006, but matched the 2000-2006 average (Figure B-2). A May through July spawning sanctuary was implemented in 2006 to reduce stress on spawners. Since the white sturgeon sport retention fishery and associated creel survey has ended well before May in each of the last two seasons, the effect of the spawning sanctuary on oversize catch cannot be determined.

Despite a guideline reduction tribal fisheries failed to reach their white sturgeon guideline 2006, but exceeded it by $10 \%$ in 2007 with a harvest of 607 white sturgeon. Downward trends in commercial fisheries correspond to changes in guidelines. Subsistence fisheries harvested an additional 100 fish, and have shown a fluctuating pattern.

\section{John Day Reservoir}

Recreational effort initially rose following the adoption of the 560 fish guideline in 1997, with the highest HPUE and the second highest harvest since 1989. Harvest peaked in 1998, and effort peaked in 1999. Effort, harvest, and HPUE declined substantially after their peak, and resulted in lowering both the recreational and commercial guidelines in 2002 to 165 fish and 335 fish, respectively. Since then the season length has steadily decreased and HPUE has trended upward. The proportion of effort attributed to boat and bank anglers has remained relatively stable since 1989 (generally favoring boat anglers). Size composition of the recreational harvest in 2007 showed $78 \%$ of the harvested fish were in the smallest 15 $\mathrm{cm}$ of the legal-size range (122-137 cm TL) as compared to an average of 85\% for 2001-2006.

The oversize percentage of total catch in the John Day Reservoir sport fishery has averaged 7.7 times higher from 1997 through 2005 than in 1996 (Figure B-2), and has been as high as 12.8\%. From 1995 through 2007 it has averaged 2.6 times higher for John Day than for The Dalles Reservoir, and 3.5 times higher than for Bonneville Reservoir. Oversize catch in John Day Reservoir has ranged from a low of 16 in 1996 to a high of 1,037 in 2004 (Table B-8). Beginning in 2006, a May - July spawning sanctuary closure was implemented for 1.5 miles downstream of McNary Dam. While it is too early to be certain of its effect, the oversize handle in 2007 dropped to the second lowest since 1996. However, this decrease may also be at least partly due to the earlier season closure, and partly to an effort shift to Bonneville Reservoir during the sanctuary closure.

The commercial harvest guideline was exceeded in 2005, and except for 2003 and 2007 was nearly reached each year since 2001. Commercial harvest has been relatively stable since the guideline change in 2002 (Table B-7). Subsistence fisheries in 2007 harvested an additional 17 fish, which is the lowest since 1991. Except for substantial increases in 1994-1996, subsistence harvest has averaged 36 fish per year since 1993. 


\section{PLANS FOR NEXT YEAR}

WDFW will monitor Zone 6 sport and treaty Indian commercial fisheries in 2008. We will work with ODFW and CRITFC during the summer of 2008 to assess the status of the white sturgeon population in The Dalles Reservoir. We will obtain breeding adult white sturgeon, from which we can collect paired

gonad-tissue and blood samples, to help MSU determine sex and stage of maturity. During the fall of 2008 we will work with ODFW and CRITFC in white sturgeon recruitment indexing in McNary, John Day, The Dalles, and Bonneville reservoirs on the Columbia River. These activities will be reported in next year's annual progress report.

\section{REFERENCES}

Kern, J.C., M.L. Hughes, and T.A. Rien. 2004. Report A. Pages 4 to 45 in D.L. Ward, editor. White sturgeon mitigation and restoration in the Columbia and Snake rivers upstream from Bonneville Dam. Annual Progress Report April 2002 - March 2003. Report to Bonneville Power Administration (Project 86-50), Portland, Oregon.

Hale, D.A., and B.W. James. 1993. Sport and commercial fisheries in the Columbia River between Bonneville and McNary dams, 1987-1991. Pages 287-342 in R.C. Beamesderfer and A.A. Nigro, editors. Status and habitat requirements of the white sturgeon populations in the Columbia River downstream from McNary Dam, volume II. Final report (Contract DE-AI79-86BP63584) to Bonneville Power Administration, Portland, Oregon.

M.L. Hughes, Kern, J.C., and T.A. Rien. 2006. Report A. Pages 6-45 in T.A. Rein, editor. White sturgeon mitigation and restoration in the Columbia and Snake rivers upstream from Bonneville Dam. Annual Progress Report April 2004 - March 2005. Report to Bonneville Power Administration (Project 86-50), Portland, Oregon.

James, B.W., D.A. Hale, J.D. DeVore, and B.L. Parker. 1996. Report B. Pages 37-71 in D. L. Ward, editor. Effects of mitigative measures on productivity of white sturgeon populations in the Columbia River downstream from McNary Dam, and determine the status and habitat requirements of white sturgeon populations in the Columbia and Snake rivers upstream of McNary Dam. Annual Progress Report to Bonneville Power Administration (Project 86-50), Portland, Oregon.

James, B.W., D.R. Gilliland, B.J. Cady, and J.D. DeVore. 2001. Report B. Pages 43-64 in D. L. Ward, editor. Effects of mitigative measures on productivity of white sturgeon populations in the Columbia River downstream from McNary Dam, and determine the status and habitat requirements of white sturgeon populations in the Columbia and Snake rivers upstream of McNary Dam. Annual Progress Report April 1999 - March 2000. Report to Bonneville Power Administration (Project 86-50), Portland, Oregon. 
North, J.A., T.A. Rein, and R.A. Farr. 1999. Report A. Pages 6 to 54 in D.L. Ward, editor. Effects of mitigative measures on productivity of white sturgeon populations in the Columbia River downstream from McNary Dam, and determine the status and habitat requirements of white sturgeon populations in the Columbia and Snake rivers upstream of McNary Dam. Annual Progress Report April 1997 - March 1998. Report to Bonneville Power Administration (Project 86-50), Portland, Oregon.

\section{APPENDIX}
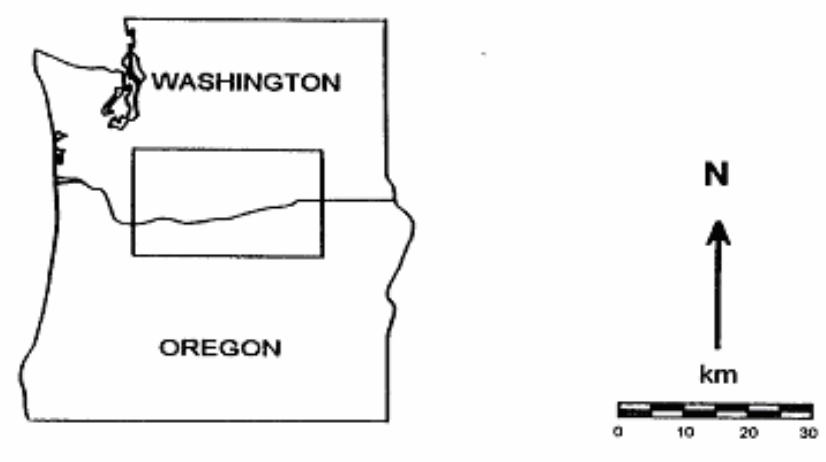

McNary Dam

(RK 470)

Crow Butte Island (RK 422)

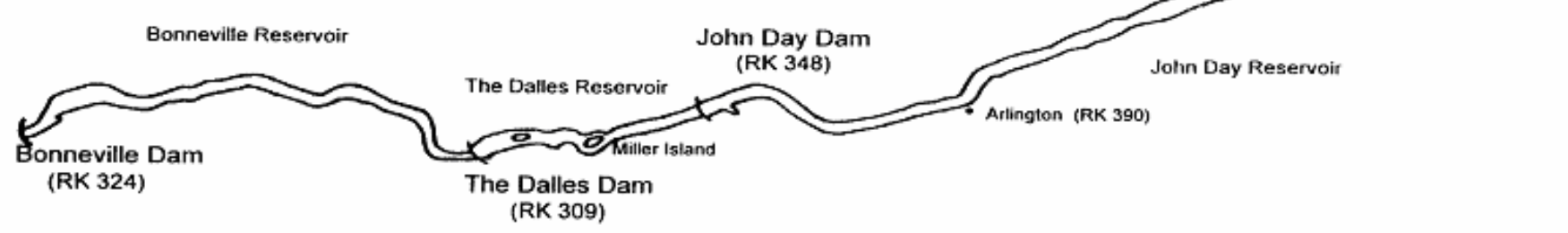

Columbia River

Figure B-1. The recreational fishery survey on the Columbia River occurs throughout Bonneville and The Dalles Reservoirs, and from Crow Butte Island upstream to McNary Dam on John Day Reservoir. Commercial fisheries occur throughout all three reservoirs. 


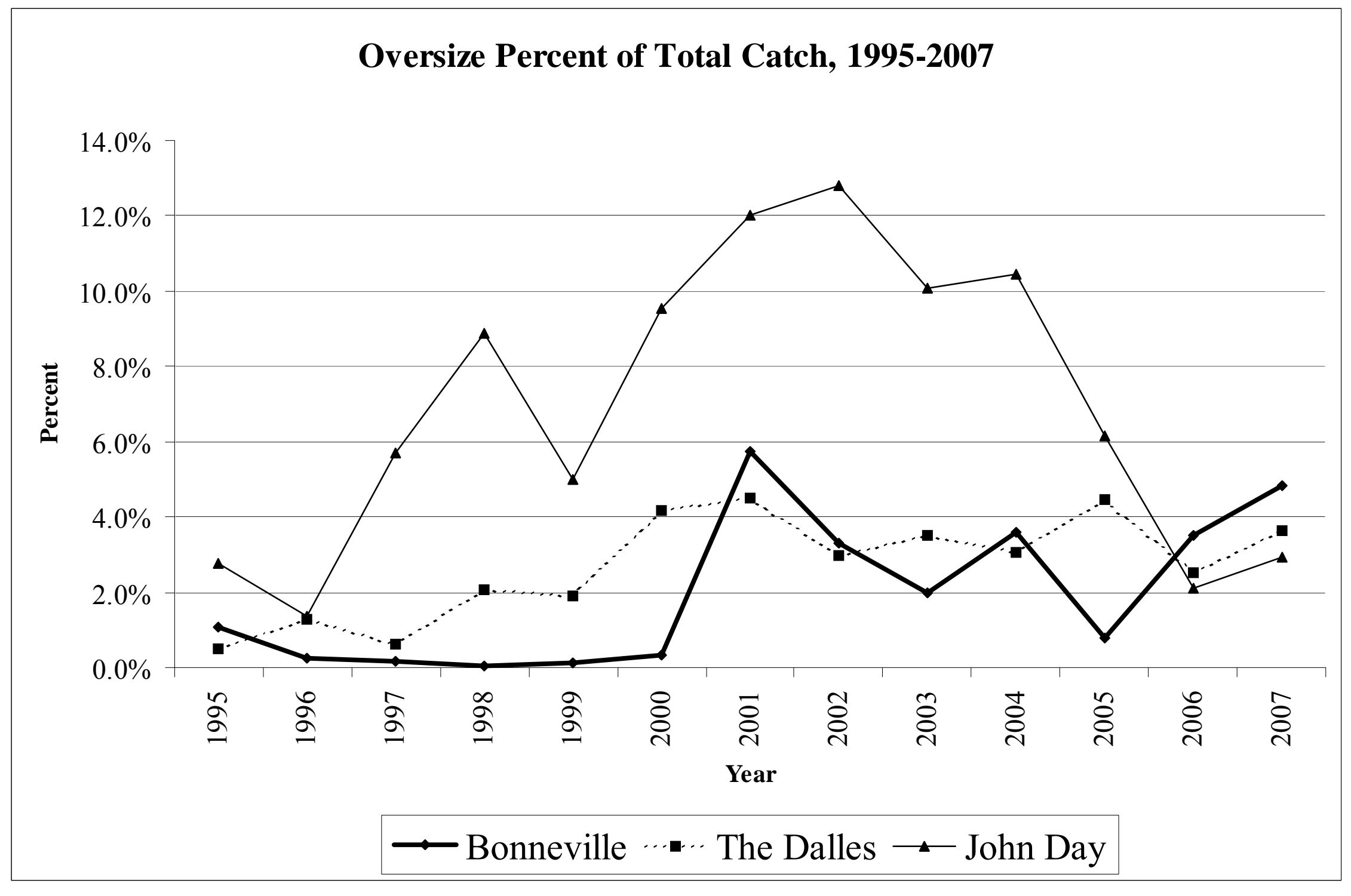

Figure B-2. Percent of total catch represented by oversize sturgeon in Zone 6 reservoirs, 1995-2007. 
Table B-1. Combined Washington and Oregon recreational fishery angling effort estimates for Bonneville Reservoir, January 1 through July 29, 2007; The Dalles Reservoir, January 1 through March 28, 2007; and John Day Reservoir, January 1 through June 10, 2007.

\begin{tabular}{|c|c|c|c|c|c|c|}
\hline \multirow{2}{*}{$\begin{array}{l}\text { Species } \\
\text { Method }\end{array}$} & \multicolumn{2}{|c|}{ Bonneville } & \multicolumn{2}{|c|}{ The Dalles } & \multicolumn{2}{|c|}{ John Day $^{1}$} \\
\hline & Hours & Trips & Hours & Trips & Hours & Trips \\
\hline \multicolumn{7}{|l|}{ Sturgeon } \\
\hline Bank & 19,590 & 3,838 & 7,599 & 1,063 & 4,884 & 955 \\
\hline Boat & 26,625 & 4,907 & 3,677 & 660 & 26,881 & 4,532 \\
\hline Total & 46,215 & 8,745 & 11,276 & 1,723 & 31,765 & 5,487 \\
\hline \multicolumn{7}{|l|}{ Salmonids $^{2}$} \\
\hline Bank & 5,915 & 725 & 195 & 41 & 3,915 & 732 \\
\hline Boat & 2,094 & 467 & 1,883 & 325 & 138 & 22 \\
\hline Total & 8,009 & 1,192 & 2,078 & 366 & 4,053 & 754 \\
\hline \multicolumn{7}{|l|}{ Shad } \\
\hline Bank & 953 & 297 & 0 & 0 & 25 & 9 \\
\hline Boat & 148 & 53 & 0 & 0 & 160 & 39 \\
\hline Total & 1,101 & 350 & 0 & 0 & 185 & 48 \\
\hline \multicolumn{7}{|l|}{ Walleye } \\
\hline Bank & 119 & 24 & 243 & 63 & 57 & 16 \\
\hline Boat & 2,490 & 597 & 9,198 & 1,616 & 38,754 & 6,396 \\
\hline Total & 2,609 & 621 & 9,441 & 1,679 & 38,811 & 6,412 \\
\hline \multicolumn{7}{|l|}{ Basses $^{3}$} \\
\hline Bank & 944 & 334 & 23 & 11 & 621 & 213 \\
\hline Boat & 5,673 & 1,308 & 0 & 0 & 16,691 & 3,198 \\
\hline Total & 6,617 & 1,642 & 23 & 11 & 17,312 & 3,411 \\
\hline \multicolumn{7}{|c|}{ Northern Pikeminnow } \\
\hline Bank & 6,690 & 838 & 0 & 0 & 419 & 48 \\
\hline Boat & 5,773 & 914 & 0 & 0 & 0 & 0 \\
\hline Total & 12,463 & 1,752 & 0 & 0 & 419 & 48 \\
\hline \multicolumn{7}{|l|}{ Other } \\
\hline Bank & 598 & 165 & 101 & 23 & 731 & 287 \\
\hline Boat & 330 & 45 & 101 & 16 & 1,619 & 431 \\
\hline Total & 928 & 210 & 202 & 39 & 2,350 & 718 \\
\hline \multicolumn{7}{|l|}{ Tournament } \\
\hline Bank & 0 & 0 & 0 & 0 & 0 & 0 \\
\hline Boat & 1,616 & 174 & 0 & 0 & 1,505 & 186 \\
\hline Total & 1,616 & 174 & 0 & 0 & 1,505 & 186 \\
\hline \multicolumn{7}{|c|}{ Combined total } \\
\hline Bank & 34,809 & 6,221 & 8,161 & 1,201 & 10,652 & 2,260 \\
\hline Boat & 44,749 & 8,465 & 14,859 & 2,617 & 85,748 & 14,804 \\
\hline Total & 79,558 & 14,686 & 23,020 & 3,818 & 96,400 & 17,064 \\
\hline \multicolumn{7}{|c|}{$\begin{array}{l}\text { Since no sampling was conducted in John Day Reservoir in January and February, } \\
\text { these estimates are based only on data from March-June sampling. }\end{array}$} \\
\hline${ }^{2}$ Includes c & and steell & ad. & & & & \\
\hline${ }^{3}$ Includes la & smallmo & ass. & & & & \\
\hline
\end{tabular}


Table B-2. Combined Washington and Oregon recreational fishery harvest, and catch and release estimates for Bonneville Reservoir, January 1 through July 29, 2007; The Dalles Reservoir, January 1 through March 28, 2007; and John Day Reservoir, January 1 through June 10, 2007.

\begin{tabular}{|c|c|c|c|}
\hline Species & Bonneville & The Dalles & John Day \\
\hline \multicolumn{4}{|l|}{ White sturgeon ${ }^{1}$} \\
\hline Legals kept & 682 & 108 & 249 \\
\hline Sublegals released & 16,711 & 1,192 & 5,265 \\
\hline Legals released & 201 & 3 & 76 \\
\hline Oversize released & 895 & 49 & 169 \\
\hline Total released & 17,807 & 1,244 & 5,510 \\
\hline \multicolumn{4}{|l|}{ Chinook salmon ${ }^{2}$} \\
\hline Adults kept & 47 & 0 & 102 \\
\hline Jacks kept & 44 & 0 & 2 \\
\hline Total kept & 91 & 0 & 104 \\
\hline Released & 10 & 0 & 19 \\
\hline \multicolumn{4}{|l|}{ Coho salmon ${ }^{3}$} \\
\hline Adults kept & 0 & 0 & 0 \\
\hline Jacks kept & 0 & 0 & 0 \\
\hline Total & 0 & 0 & 0 \\
\hline \multicolumn{4}{|l|}{ Steelhead $^{4}$} \\
\hline Kept & 37 & 160 & 136 \\
\hline Released & 0 & 24 & 91 \\
\hline \multicolumn{4}{|l|}{ American shad } \\
\hline Kept & 702 & 0 & 87 \\
\hline Released & 197 & 0 & 229 \\
\hline \multicolumn{4}{|l|}{ Walleye } \\
\hline Kept & 457 & 909 & 6,613 \\
\hline Released & 50 & 81 & 1,167 \\
\hline \multicolumn{4}{|l|}{ Bass } \\
\hline Kept & 1,014 & 0 & 4,522 \\
\hline Released & 7,356 & 0 & 18,536 \\
\hline Northern pikeminnow kept & 4,095 & 7 & 48 \\
\hline Other resident fish kept & 17 & 9 & 590 \\
\hline
\end{tabular}

${ }^{1}$ White sturgeon seasons were closed to retention July 30 - December 31 in Bonneville Reservoir, March 29 - December 31 in The Dalles Reservoir,and June 11 - December 31 in John Day Reservoir.

${ }^{2}$ Chinook seasons were closed to retention January 1 - March 15, May 4 - June 5, July 3 - July 31, and September 20 - December 31 in all three reservoirs.

${ }^{3}$ Coho seasons were closed to retention January 1 - July 31.

${ }^{4}$ Steelhead seasons were closed to retention April 1 - June 15. 
Table B-3. Estimates of recreational fishery angler trips for white sturgeon, white sturgeon harvest, and harvest per angler trip (HPUE) for Bonneville Reservoir, January 1 through July 29, 2007; The Dalles Reservoir, January 1 through March 28, 2007; and John Day Reservoir, January 1 through June 10, 2007.

\begin{tabular}{|c|c|c|c|c|c|c|c|c|c|}
\hline \multirow{2}{*}{$\begin{array}{l}\text { Month } \\
\text { Method }\end{array}$} & \multicolumn{3}{|c|}{ Bonneville } & \multicolumn{3}{|c|}{ The Dalles } & \multicolumn{3}{|c|}{ John Day } \\
\hline & Trips & HPUE & Harvest & Trips & HPUE & Harvest & Trips & HPUE & Harvest \\
\hline \multicolumn{10}{|l|}{ January } \\
\hline Bank & 448 & 0.02 & 8 & 236 & 0.03 & 8 & 0 & 0.00 & $1^{1}$ \\
\hline Boat & 267 & 0.02 & 5 & 211 & 0.16 & 33 & 0 & 0.00 & $0^{1}$ \\
\hline Total & 715 & $\overline{0.02}$ & $\overline{13}$ & 447 & $\overline{0.09}$ & $\overline{41}$ & $\overline{0}$ & $\overline{0.00}$ & $\overline{1}^{1}$ \\
\hline \multicolumn{10}{|l|}{ February } \\
\hline Bank & 360 & 0.02 & 6 & 246 & 0.00 & 0 & 0 & 0.00 & $1^{1}$ \\
\hline Boat & 357 & 0.00 & 0 & 162 & 0.00 & 0 & 0 & 0.00 & $4^{1}$ \\
\hline Total & 717 & $\overline{0.01}$ & $\overline{6}$ & $\overline{408}$ & 0.00 & $\overline{0}$ & $\overline{0}$ & $\overline{0.00}$ & $5^{1}$ \\
\hline \multicolumn{10}{|l|}{ March } \\
\hline Bank & 573 & 0.01 & 5 & 581 & 0.02 & 14 & 213 & 0.01 & 3 \\
\hline Boat & 469 & 0.04 & 19 & 287 & 0.18 & 53 & 1,356 & 0.06 & 76 \\
\hline Total & $\overline{1,042}$ & 0.02 & 24 & 868 & 0.08 & 67 & 1,569 & 0.05 & 79 \\
\hline \multicolumn{10}{|l|}{ April } \\
\hline Bank & 354 & 0.03 & 9 & 0 & $0.00^{2}$ & 0 & 345 & 0.01 & 4 \\
\hline Boat & 484 & 0.00 & 0 & 0 & $0.00^{2}$ & 0 & 1,550 & 0.04 & 60 \\
\hline Total & 838 & $\overline{0.01}$ & $\overline{9}$ & $\overline{0}$ & $\overline{0.00}^{2}$ & $\overline{0}$ & $\overline{1,895}$ & $\overline{0.03}$ & $\overline{64}$ \\
\hline \multicolumn{10}{|l|}{ May } \\
\hline Bank & 552 & 0.06 & 33 & 0 & 0.00 & 0 & 220 & 0.01 & 2 \\
\hline Boat & 575 & 0.02 & 12 & 0 & 0.00 & 0 & 1,170 & 0.04 & 41 \\
\hline Total & 1,127 & 0.04 & 45 & 0 & 0.00 & 0 & 1,390 & 0.03 & 43 \\
\hline \multicolumn{10}{|l|}{ June } \\
\hline Bank & 642 & 0.13 & 81 & 0 & 0.00 & 0 & 177 & $0.02^{2}$ & 4 \\
\hline Boat & 1,352 & 0.15 & 197 & 0 & 0.00 & 0 & 456 & $0.12^{2}$ & 53 \\
\hline Total & 1,994 & 0.14 & 278 & 0 & 0.00 & 0 & 633 & $0.09^{2}$ & 57 \\
\hline \multicolumn{10}{|l|}{ July } \\
\hline Bank & 909 & $0.09^{2}$ & 79 & 0 & 0.00 & 0 & 0 & 0.00 & 0 \\
\hline Boat & 1,403 & $0.16^{2}$ & 228 & 0 & 0.00 & 0 & 0 & 0.00 & 0 \\
\hline Total & 2,312 & $0.13^{2}$ & 307 & 0 & 0.00 & 0 & 0 & 0.00 & 0 \\
\hline \multicolumn{10}{|l|}{ Combined } \\
\hline Bank & 3,838 & $0.06^{2}$ & 221 & 1,063 & $0.02^{2}$ & 22 & 955 & $0.02^{2}$ & 15 \\
\hline Boat & 4,907 & $0.09^{2}$ & 461 & 660 & $0.13^{2}$ & 86 & 4,532 & $0.05^{2}$ & 234 \\
\hline Total & 8,745 & $0.08^{2}$ & 682 & 1,723 & $0.06^{2}$ & 108 & 5,487 & $0.05^{2}$ & 249 \\
\hline
\end{tabular}

1 No creel sampling was conducted in January and February. Estimates are based on historical averages.

2 Harvest per angler trip calculated for the portion of the month or year when retention was allowed. 
Table B-4. Number of sturgeon anglers interviewed and numbers of white sturgeon kept and released reported during sampling of recreational fisheries in Bonneville Reservoir, January 1 through July 29, 2007; The Dalles Reservoir, January 1 through March 28, 2007; and John Day Reservoir, January 1 through June 10, 2007.

\begin{tabular}{|c|c|c|c|c|c|c|}
\hline $\begin{array}{l}\text { Reservoir } \\
\text { Method/Month }\end{array}$ & $\begin{array}{l}\text { Anglers } \\
\text { checked }\end{array}$ & $\begin{array}{l}\text { Hours } \\
\text { fished }\end{array}$ & $\begin{array}{l}\text { Sublegal } \\
\text { released }\end{array}$ & $\begin{array}{r}\text { Legal } \\
\text { released }\end{array}$ & $\begin{array}{l}\text { Legal } \\
\text { kept }\end{array}$ & $\begin{array}{r}\text { Oversize } \\
\text { released }\end{array}$ \\
\hline \multicolumn{7}{|l|}{ Bonneville } \\
\hline \multicolumn{7}{|l|}{ Bank } \\
\hline January & 134 & 253 & 28 & 0 & 1 & 0 \\
\hline February & 130 & 305 & 40 & 1 & 1 & 0 \\
\hline March & 185 & 431 & 42 & 0 & 1 & 2 \\
\hline April & 200 & 471 & 78 & 0 & 2 & 2 \\
\hline May & 155 & 386 & 158 & 1 & 5 & 1 \\
\hline June & 264 & 747 & 392 & 6 & 18 & 5 \\
\hline July & 252 & 851 & 367 & 7 & 13 & 2 \\
\hline Bank total & $\overline{1,320}$ & $\overline{3,444}$ & $\overline{1,105}$ & 15 & 41 & $\overline{12}$ \\
\hline \multicolumn{7}{|l|}{ Boat } \\
\hline January & 62 & 346 & 50 & 0 & 1 & 1 \\
\hline February & 21 & 70 & 2 & 0 & 0 & 0 \\
\hline March & 42 & 191 & 31 & 0 & 1 & 0 \\
\hline April & 73 & 328 & 70 & 0 & 0 & 1 \\
\hline May & 60 & 299 & 74 & 1 & 1 & 2 \\
\hline June & 133 & 788 & 302 & 2 & 18 & 44 \\
\hline July & 138 & 850 & 498 & 8 & 22 & 32 \\
\hline Boat total & 529 & $\overline{2,872}$ & $\overline{1,027}$ & $\overline{11}$ & 43 & 80 \\
\hline Combined total & $\overline{1,849}$ & $\overline{6,316}$ & $\overline{2,132}$ & $\overline{26}$ & $\overline{84}$ & 92 \\
\hline \multicolumn{7}{|l|}{ The Dalles } \\
\hline \multicolumn{7}{|l|}{ Bank } \\
\hline January & 126 & 472 & 11 & 0 & 1 & 5 \\
\hline February & 70 & 247 & 3 & 0 & 0 & 0 \\
\hline March & 206 & 829 & 46 & 0 & 3 & 2 \\
\hline April & 0 & 0 & 0 & 0 & 0 & 0 \\
\hline Bank total & 402 & $\overline{1,548}$ & 60 & $\overline{0}$ & 4 & 7 \\
\hline \multicolumn{7}{|l|}{ Boat } \\
\hline January & 83 & 533 & 102 & 1 & 8 & 3 \\
\hline February & 19 & 89 & 2 & 0 & 0 & 0 \\
\hline March & 48 & 250 & 97 & 0 & 11 & 2 \\
\hline April & 0 & 0 & 0 & 0 & 0 & 0 \\
\hline Boat total & 150 & 872 & 201 & $\overline{1}$ & 19 & 5 \\
\hline Combined total & 552 & $\overline{2,420}$ & 261 & $\overline{1}$ & 23 & $\overline{12}$ \\
\hline
\end{tabular}


Table B-4. Continued.

\begin{tabular}{|c|c|c|c|c|c|c|}
\hline $\begin{array}{l}\text { Reservoir } \\
\text { Method/Month }\end{array}$ & $\begin{array}{l}\text { Anglers } \\
\text { checked }\end{array}$ & $\begin{array}{l}\text { Hours } \\
\text { fished }\end{array}$ & $\begin{array}{r}\text { Sublegal } \\
\text { released }\end{array}$ & $\begin{array}{r}\text { Legal } \\
\text { released }\end{array}$ & $\begin{array}{c}\text { Legal } \\
\text { kept }\end{array}$ & $\begin{array}{r}\text { Oversize } \\
\text { released }\end{array}$ \\
\hline \multicolumn{7}{|l|}{ John Day $^{1}$} \\
\hline \multicolumn{7}{|l|}{ Bank } \\
\hline January & 0 & 0 & 0 & 0 & 0 & 0 \\
\hline February & 0 & 0 & 0 & 0 & 0 & 0 \\
\hline March & 116 & 295 & 8 & 0 & 0 & 1 \\
\hline April & 157 & 333 & 7 & 0 & 0 & 0 \\
\hline May & 52 & 104 & 3 & 0 & 0 & 1 \\
\hline June & 52 & 167 & 4 & 0 & 0 & 2 \\
\hline Bank total & 377 & 899 & 22 & 0 & 0 & 4 \\
\hline \multicolumn{7}{|l|}{ Boat } \\
\hline January & 0 & 0 & 0 & 0 & 0 & 0 \\
\hline February & 0 & 0 & 0 & 0 & 0 & 0 \\
\hline March & 286 & 1,735 & 269 & 4 & 13 & 8 \\
\hline April & 222 & 1,169 & 232 & 0 & 7 & 10 \\
\hline May & 129 & 724 & 138 & 0 & 4 & 11 \\
\hline June & 86 & 718 & 73 & 1 & 8 & 3 \\
\hline Boat total & 723 & $\overline{4,346}$ & 712 & 5 & 32 & 32 \\
\hline Combined total & $\overline{1,100}$ & $\overline{5,245}$ & 734 & 5 & 32 & 36 \\
\hline
\end{tabular}

1 No creel sampling was conducted in January and February. 
Table B-5. Length frequencies of harvested white sturgeon measured during sampling of recreational fisheries in Bonneville Reservoir, January 1 through July 29, 2007; The Dalles Reservoir, January 1 through March 28, 2007; and John Day Reservoir, January 1 through June 10, 2007. Shaded areas indicate average fork length equivalents to the bottom $15 \mathrm{~cm}$ (total length of the legal size slot.

\begin{tabular}{|c|c|c|c|c|c|c|c|}
\hline $\begin{array}{l}\text { Fork } \\
\text { length } \\
(\mathrm{cm})\end{array}$ & Bonneville & $\begin{array}{l}\text { The } \\
\text { Dalles }\end{array}$ & $\begin{array}{r}\text { John } \\
\text { Day }\end{array}$ & $\begin{array}{c}\text { Fork } \\
\text { length } \\
(\mathrm{cm})\end{array}$ & Bonneville & $\begin{array}{l}\text { The } \\
\text { Dalles }\end{array}$ & $\begin{array}{l}\text { John } \\
\text { Day }\end{array}$ \\
\hline 90 & & & & 130 & 1 & & 2 \\
\hline 91 & & & & 131 & & & \\
\hline 92 & & & & 132 & & & \\
\hline 93 & & & & 133 & & 1 & \\
\hline 94 & 2 & & & 134 & 1 & & \\
\hline 95 & 6 & & & 135 & & 1 & \\
\hline 96 & 5 & & & 136 & & 1 & \\
\hline 97 & 2 & & & 137 & & & \\
\hline 98 & 6 & & & 138 & 2 & & \\
\hline 99 & 7 & & & 139 & & & 1 \\
\hline 100 & 2 & & & 140 & & & \\
\hline 101 & 4 & & & 141 & & & \\
\hline 102 & 3 & & & 142 & & & \\
\hline 103 & 6 & & & 143 & & & \\
\hline 104 & 5 & & & 144 & & & \\
\hline 105 & 2 & & & 145 & & & \\
\hline 106 & 1 & & & 146 & & & \\
\hline 107 & 2 & 1 & & 147 & & & \\
\hline 108 & 2 & & 1 & 148 & & & \\
\hline 109 & 2 & 1 & 1 & 149 & & & \\
\hline 110 & 4 & & 2 & 150 & & & \\
\hline 111 & 1 & 1 & 2 & 151 & & & \\
\hline 112 & 1 & 1 & 2 & 152 & & & \\
\hline 113 & 2 & 1 & 4 & 153 & & & \\
\hline 114 & 1 & 1 & 2 & 154 & & & \\
\hline 115 & 1 & & 2 & 155 & & & \\
\hline 116 & & 1 & 5 & 156 & & & \\
\hline 117 & & 1 & 1 & 157 & & & \\
\hline 118 & & 1 & 1 & 158 & & & \\
\hline 119 & & 3 & & 159 & & & \\
\hline 120 & & 3 & & 160 & & & \\
\hline 121 & & & 1 & 161 & & & \\
\hline 122 & & & 1 & 162 & & & \\
\hline 123 & 2 & 1 & & 163 & & & \\
\hline 124 & 2 & & & 164 & & & \\
\hline 125 & & 1 & & 165 & & & \\
\hline 126 & & 3 & 1 & 166 & & & \\
\hline 127 & 1 & & 1 & 167 & & & \\
\hline 128 & & & 2 & & . & . & . \\
\hline 129 & & & & Total & 76 & 23 & 32 \\
\hline
\end{tabular}


Table B-6. Estimated angling effort, harvest, and harvest per angler trip (HPUE) of white sturgeon from Bonneville, The Dalles, and John Day reservoirs, 1987 through 2007.

\begin{tabular}{|c|c|c|c|c|c|c|c|c|}
\hline \multirow{2}{*}{$\begin{array}{c}\text { Reservoir } \\
\text { Year }\end{array}$} & \multirow[b]{2}{*}{ Period } & \multirow[b]{2}{*}{ Trips } & \multicolumn{2}{|c|}{ Bank anglers } & \multicolumn{3}{|c|}{ Boat anglers } & \multirow{2}{*}{$\begin{array}{c}\text { Combined } \\
\text { HPUE }\end{array}$} \\
\hline & & & Harvest & HPUE & Trips & Harvest & HPUE & \\
\hline \multicolumn{9}{|c|}{ Bonneville $\left(95-138 \mathrm{~cm}\right.$ fork length interval) ${ }^{1}$} \\
\hline 1987 & $--^{2}$ & & & & & & & \\
\hline 1988 & Mar-Oct & 5,653 & 532 & 0.094 & 4,776 & 688 & 0.144 & 0.117 \\
\hline 1989 & Mar-Oct & 8,028 & 1,316 & 0.164 & 5,792 & 1,099 & 0.190 & 0.175 \\
\hline 1990 & Mar-Oct & 7,213 & 719 & 0.100 & 7,349 & 1,055 & 0.144 & 0.122 \\
\hline 1991 & $--^{2}$ & & & & & & & \\
\hline 1992 & $-{ }^{2}$ & & & & & & & \\
\hline 1993 & Mar-Oct & 7,599 & 678 & 0.089 & 6,747 & 736 & 0.109 & 0.099 \\
\hline 1994 & Mar-Oct & 7,821 & 1,024 & 0.131 & 5,329 & 1,089 & 0.204 & 0.161 \\
\hline 1995 & Feb-Apr & 2,541 & 456 & 0.180 & 1,750 & 857 & 0.490 & 0.306 \\
\hline 1996 & Jan-Mar & 3,341 & 823 & 0.246 & 1,735 & 463 & 0.267 & 0.253 \\
\hline 1997 & Jan-Apr 4 & 5,093 & 808 & 0.159 & 2,535 & 632 & 0.249 & 0.189 \\
\hline 1998 & Jan-Apr 19 & 4,913 & 358 & 0.073 & 4,990 & 1,214 & 0.243 & 0.159 \\
\hline 1999 & Jan-Apr 16 & 4,724 & 374 & 0.079 & 3,884 & 789 & 0.203 & 0.135 \\
\hline 2000 & Jan-Apr 7 & 3,724 & 425 & 0.114 & 3,187 & 779 & 0.245 & 0.174 \\
\hline 2001 & Jan-Aug 12 & 6,867 & 459 & 0.067 & 5,328 & 852 & 0.160 & 0.107 \\
\hline 2002 & $\begin{array}{l}\text { Jan-Aug 4; } \\
\text { Sep } 28 \text { - Dec }\end{array}$ & 7,838 & 644 & 0.082 & 6,423 & 867 & 0.135 & 0.106 \\
\hline 2003 & Jan-Jul 6 & 4,092 & 247 & 0.060 & 5,733 & 1,186 & 0.207 & 0.146 \\
\hline 2004 & Jan-Jun 25 & 4,195 & 212 & 0.051 & 5,327 & 574 & 0.108 & 0.083 \\
\hline 2005 & Jan-Jun 10 & 3,820 & 196 & 0.051 & 4,102 & 386 & 0.094 & 0.073 \\
\hline 2006 & Jan-Jul 23 & 4,396 & 119 & 0.027 & 5,562 & 601 & 0.108 & 0.072 \\
\hline 2007 & Jan-Jul 29 & 3,838 & 215 & 0.056 & 4,907 & 449 & 0.091 & 0.076 \\
\hline \multicolumn{9}{|c|}{ The Dalles $(110-138 \mathrm{~cm} \text { fork length interval })^{1}$} \\
\hline 1987 & Jun-Oct & 5,019 & 465 & 0.093 & 3,618 & 339 & 0.094 & 0.093 \\
\hline 1988 & Mar-Oct & 5,043 & 257 & 0.051 & 2,566 & 170 & 0.066 & 0.056 \\
\hline 1989 & Mar-Oct & 3,659 & 119 & 0.033 & 1,760 & 99 & 0.056 & 0.040 \\
\hline 1990 & $--^{2}$ & & & & & & & \\
\hline 1991 & $--^{2}$ & & & & & & & \\
\hline 1992 & $--^{2}$ & & & & & & & \\
\hline 1993 & Mar-Oct & 2,058 & 46 & 0.023 & 1,902 & 61 & 0.032 & 0.027 \\
\hline 1994 & Mar-Oct & 3,124 & 75 & 0.024 & 1,863 & 68 & 0.037 & 0.029 \\
\hline 1995 & Mar-May & 957 & 28 & 0.029 & 510 & 18 & 0.035 & 0.031 \\
\hline 1996 & Mar-Apr & 655 & 21 & 0.031 & 251 & 29 & 0.115 & 0.055 \\
\hline 1997 & Jan-May 4 & 2,278 & 119 & 0.052 & 538 & 16 & 0.030 & 0.048 \\
\hline 1998 & Jan-Jun 7 & 4,102 & 455 & 0.111 & 1,319 & 296 & 0.225 & 0.139 \\
\hline 1999 & Jan-Jun 11 & 5,396 & 411 & 0.076 & 1,804 & 207 & 0.115 & 0.086 \\
\hline 2000 & Jan-Jun 18 & 4,202 & 260 & 0.062 & 2,953 & 472 & 0.160 & 0.102 \\
\hline 2001 & Jan-Apr 8 & 2,124 & 100 & 0.047 & 1,858 & 456 & 0.245 & 0.140 \\
\hline 2002 & Jan-Jul 12 & 3,879 & 260 & 0.067 & 4,140 & 556 & 0.134 & 0.102 \\
\hline 2003 & Jan-Jun 20 & 3,797 & 93 & 0.025 & 2,721 & 312 & 0.115 & 0.062 \\
\hline 2004 & Jan-Jun 27 & 3,259 & 169 & 0.052 & 3,074 & 284 & 0.092 & 0.072 \\
\hline 2005 & Jan-Jun 24 & 3,531 & 66 & 0.019 & 3,715 & 263 & 0.071 & 0.045 \\
\hline 2006 & Jan-Apr 8 & 1,411 & 12 & 0.009 & 1,039 & 75 & 0.072 & 0.036 \\
\hline 2007 & Jan-Mar 28 & 1,063 & 20 & 0.019 & 660 & 79 & 0.119 & 0.057 \\
\hline
\end{tabular}


Table B-6. Continued.

\begin{tabular}{|c|c|c|c|c|c|c|c|c|}
\hline \multirow{2}{*}{$\begin{array}{c}\text { Reservoir } \\
\text { Year }\end{array}$} & \multirow[b]{2}{*}{ Period } & \multicolumn{3}{|c|}{ Bank anglers } & \multicolumn{3}{|c|}{ Boat anglers } & \multirow{2}{*}{$\begin{array}{c}\text { Combined } \\
\text { HPUE }\end{array}$} \\
\hline & & Trips & Harvest & HPUE & Trips & Harvest & HPUE & \\
\hline \multicolumn{9}{|c|}{ 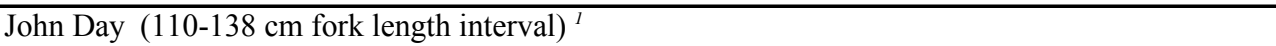 } \\
\hline 1987 & $--^{2}$ & & & & & & & \\
\hline 1988 & $--^{2}$ & & & & & & & \\
\hline 1989 & May-Jul & 3,572 & 22 & 0.006 & 3,401 & 34 & 0.010 & 0.008 \\
\hline 1990 & Mar-Dec & 3,806 & 33 & 0.009 & 3,063 & 82 & 0.027 & 0.017 \\
\hline 1991 & Apr-Sep & 1,977 & 36 & 0.018 & 2,463 & 73 & 0.030 & 0.024 \\
\hline 1992 & $--^{2}$ & & & & & & & \\
\hline 1993 & Mar-Oct & 3,208 & 56 & 0.018 & 4,466 & 111 & 0.025 & 0.022 \\
\hline 1994 & Mar-Oct & 3,221 & 42 & 0.013 & 6,860 & 164 & 0.024 & 0.020 \\
\hline 1995 & Mar-May & 1,891 & 12 & 0.006 & 2,407 & 30 & 0.013 & 0.010 \\
\hline 1996 & Mar-Apr & 1,524 & 17 & 0.011 & 1,396 & 27 & 0.020 & 0.015 \\
\hline 1997 & Feb-Aug & 4,780 & 166 & 0.035 & 5,968 & 287 & 0.048 & 0.042 \\
\hline 1998 & Jan-Oct & 5,531 & 161 & 0.029 & 8,540 & 371 & 0.043 & 0.038 \\
\hline 1999 & Jan-Dec & 6,542 & 99 & 0.015 & 10,110 & 278 & 0.028 & 0.023 \\
\hline 2000 & Jan-Dec & 5,204 & 44 & 0.008 & 9,230 & 280 & 0.030 & 0.022 \\
\hline 2001 & Jan-Dec & 5,939 & 109 & 0.018 & 8,941 & 160 & 0.018 & 0.018 \\
\hline 2002 & Jan-Aug 23 & 2,794 & 45 & 0.016 & 5,877 & 111 & 0.019 & 0.018 \\
\hline 2003 & Jan-Jul 27 & 3,212 & 35 & 0.011 & 5,465 & 128 & 0.023 & 0.019 \\
\hline 2004 & Jan-Jul 11 & 3,203 & 45 & 0.014 & 4,756 & 149 & 0.031 & 0.024 \\
\hline 2005 & Jan-Jul 10 & 4,113 & 8 & 0.002 & 5,025 & 81 & 0.016 & 0.010 \\
\hline 2006 & Jan-Jun & 2,094 & 45 & 0.021 & 2,659 & 85 & 0.032 & 0.027 \\
\hline $2007^{3}$ & Jan-Jun 10 & 955 & 14 & 0.014 & 4,532 & 212 & 0.047 & 0.041 \\
\hline
\end{tabular}

\footnotetext{
${ }^{1}$ Harvest estimates exclude legally kept fish with fork lengths outside the given ranges for each reservoir. Legal size is based on total length.

${ }^{2}$ Minimal or no sampling.

${ }^{3}$ The January and February portion of estimates are based on historical averages.
} 
Table B-7. Sturgeon Management Task Force (SMTF) harvest guidelines and estimated harvest of white sturgeon from Bonneville, The Dalles, and John Day reservoirs, 1991 through 2007.

\begin{tabular}{|c|c|c|c|c|c|c|c|c|}
\hline \multirow{2}{*}{$\begin{array}{l}\text { Fishery } \\
\text { Year }\end{array}$} & \multicolumn{2}{|c|}{ Bonneville } & \multicolumn{2}{|c|}{ The Dalles } & \multicolumn{2}{|c|}{ John Day } & \multirow{2}{*}{$\begin{array}{c}\text { Unspecified } \\
\text { Harvest }\end{array}$} & \multirow[b]{2}{*}{ Total } \\
\hline & Guideline & Harvest & Guideline & Harvest & Guideline & Harvest & & \\
\hline \multicolumn{9}{|c|}{ Recreational } \\
\hline \multicolumn{9}{|l|}{ Harvest } \\
\hline 1991 & 1,350 & 2,270 & 100 & 199 & 100 & 150 & 0 & 2,619 \\
\hline 1992 & 1,350 & 1,717 & 100 & 139 & 100 & 147 & 0 & 2,003 \\
\hline 1993 & 1,350 & 2,307 & 100 & 158 & 100 & 144 & 0 & 2,609 \\
\hline 1994 & 1,350 & 2,223 & 100 & 154 & 100 & 234 & 0 & 2,611 \\
\hline 1995 & 1,350 & 1,370 & 100 & 50 & 100 & 53 & 0 & 1,473 \\
\hline 1996 & 1,350 & 1,353 & 100 & 80 & 100 & 62 & 0 & 1,495 \\
\hline 1997 & 1,520 & 1,463 & 200 & 178 & 560 & 464 & 0 & 2,105 \\
\hline 1998 & 1,520 & 1,626 & $600-800$ & 857 & 560 & 593 & 0 & 3,076 \\
\hline 1999 & 1,520 & 1,236 & $600-800$ & 694 & 560 & 422 & 0 & 2,352 \\
\hline 2000 & 1,520 & 1,262 & $600-800$ & 809 & 560 & 434 & 0 & 2,505 \\
\hline 2001 & 1,520 & 1,426 & 700 & 677 & 560 & 299 & 0 & 2,402 \\
\hline 2002 & 1,520 & 1,560 & 700 & 878 & 165 & 187 & 0 & 2,625 \\
\hline 2003 & 1,700 & 1,542 & 400 & 447 & 165 & 186 & 0 & 2,175 \\
\hline 2004 & 700 & 852 & 400 & 530 & 165 & 229 & 0 & 1,611 \\
\hline 2005 & 700 & 596 & 400 & 382 & 165 & 128 & 0 & 1,106 \\
\hline 2006 & 700 & 727 & 100 & 93 & 165 & 142 & 0 & 962 \\
\hline 2007 & 700 & 682 & 100 & 108 & 165 & $249^{1}$ & 0 & 1,039 \\
\hline \multicolumn{9}{|c|}{ Indian commercial } \\
\hline \multicolumn{9}{|l|}{ Harvest } \\
\hline 1991 & 1,250 & 999 & 300 & 457 & 100 & 39 & 0 & 1,495 \\
\hline 1992 & 1,250 & 1,146 & 300 & 431 & 100 & 23 & 0 & 1,600 \\
\hline 1993 & 1,250 & 1,415 & 300 & 579 & 100 & 12 & 0 & 2,006 \\
\hline 1994 & 1,250 & 1,176 & 300 & 309 & 100 & 117 & 0 & 1,602 \\
\hline 1995 & 1,250 & 1,421 & 300 & 312 & 100 & 308 & 0 & 2,041 \\
\hline 1996 & 1,250 & 1,005 & 300 & 230 & 100 & 360 & 0 & 1,595 \\
\hline 1997 & 1,300 & 1,852 & 400 & 498 & 1,160 & 1,260 & 0 & 3,610 \\
\hline 1998 & 1,300 & 1,462 & $1,000-1,200$ & 1,108 & 1,160 & 1,100 & 0 & 3,670 \\
\hline 1999 & 1,300 & 1,280 & $1,000-1,200$ & 1,051 & 1,160 & 760 & 0 & 3,091 \\
\hline 2000 & 1,300 & 1,165 & $1,000-1,200$ & 1,342 & 1,160 & 788 & 0 & 3,295 \\
\hline 2001 & 1,300 & 1,287 & 1,100 & 1,215 & 1,160 & 755 & 0 & 3,257 \\
\hline 2002 & 1,300 & 472 & 1,100 & 1,152 & 335 & 326 & 0 & 1,950 \\
\hline 2003 & 1,200 & 379 & 900 & 811 & 335 & 251 & 0 & 1,441 \\
\hline 2004 & 400 & 464 & 900 & 975 & 335 & 309 & 0 & 1,748 \\
\hline 2005 & 400 & 550 & 900 & 831 & 335 & 360 & 0 & 1,741 \\
\hline 2006 & 400 & 153 & 550 & 397 & 335 & 312 & 0 & 862 \\
\hline 2007 & 400 & 285 & 550 & 607 & 335 & 232 & 0 & 1,124 \\
\hline
\end{tabular}


Table B-7. Continued.

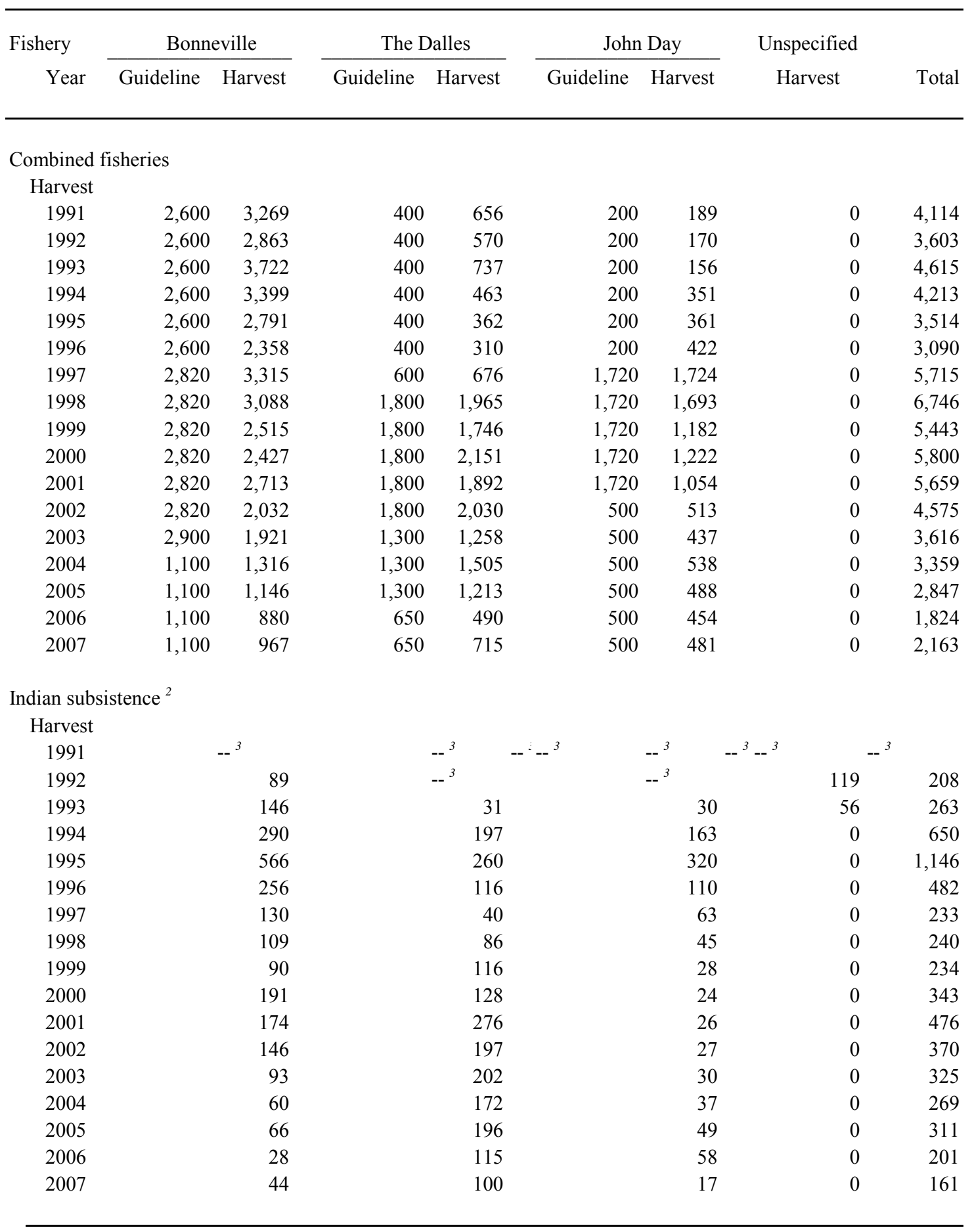

${ }^{1}$ Since no sampling was conducted in John Day Reservoir in January and February, the sturgeon harvest estimate for those months is based on historical averages.

2 The SMTF did not establish harvest guidelines for the subsistence fishery, however, the expected annual subsistence harvest was 300 white sturgeon for 1991 through 2007.

3 Not available. 
Table B-8. Oversize sturgeon sport catch and percent of total sport catch in Zone 6 reservoirs, 1995 $2007 .{ }^{1}$

\begin{tabular}{|c|c|c|c|c|c|c|c|c|c|}
\hline \multirow[b]{2}{*}{ Year } & \multicolumn{3}{|c|}{ Bonneville $^{2}$} & \multicolumn{3}{|c|}{ The Dalles ${ }^{3}$} & \multicolumn{3}{|c|}{ John Day $^{4}$} \\
\hline & $\begin{array}{c}\text { Oversize } \\
\text { Catch }\end{array}$ & $\begin{array}{r}\text { Total } \\
\text { Catch }\end{array}$ & $\begin{array}{l}\% \text { of } \\
\text { Total }\end{array}$ & $\begin{array}{c}\text { Oversize } \\
\text { Catch }\end{array}$ & $\begin{array}{r}\text { Total } \\
\text { Catch }\end{array}$ & $\begin{array}{l}\% \text { of } \\
\text { Total }\end{array}$ & $\begin{array}{c}\text { Oversize } \\
\text { Catch }\end{array}$ & $\begin{array}{l}\text { Total } \\
\text { Catch }\end{array}$ & $\begin{array}{l}\text { \% of } \\
\text { Total }\end{array}$ \\
\hline 1995 & 156 & 14,662 & $1.1 \%$ & 11 & 2,132 & $0.5 \%$ & 143 & 5,192 & $2.8 \%$ \\
\hline 1996 & 29 & 10,952 & $0.3 \%$ & 30 & 2,380 & $1.3 \%$ & 16 & 1,187 & $1.3 \%$ \\
\hline 1997 & 22 & 13,398 & $0.2 \%$ & 15 & 2,468 & $0.6 \%$ & 553 & 9,715 & $5.7 \%$ \\
\hline 1998 & 11 & 18,097 & $0.1 \%$ & 157 & 7,630 & $2.1 \%$ & 883 & 9,944 & $8.9 \%$ \\
\hline 1999 & 15 & 12,476 & $0.1 \%$ & 170 & 8,909 & $1.9 \%$ & 591 & 11,857 & $5.0 \%$ \\
\hline 2000 & 49 & 14,984 & $0.3 \%$ & 404 & 9,694 & $4.2 \%$ & 876 & 9,196 & $9.5 \%$ \\
\hline 2001 & 1,378 & 24,039 & $5.7 \%$ & 244 & 5,417 & $4.5 \%$ & 1,034 & 8,608 & $12.0 \%$ \\
\hline 2002 & 980 & 29,698 & $3.3 \%$ & 303 & 10,218 & $3.0 \%$ & 977 & 7,640 & $12.8 \%$ \\
\hline 2003 & 583 & 29,573 & $2.0 \%$ & 355 & 10,140 & $3.5 \%$ & 852 & 8,439 & $10.1 \%$ \\
\hline 2004 & 797 & 22,083 & $3.6 \%$ & 369 & 12,059 & $3.1 \%$ & 1,037 & 9,907 & $10.5 \%$ \\
\hline 2005 & 139 & 18,115 & $0.8 \%$ & 556 & 12,510 & $4.4 \%$ & 388 & 6,304 & $6.2 \%$ \\
\hline $2006^{5}$ & 937 & 26,609 & $3.5 \%$ & 40 & 1,587 & $2.5 \%$ & 99 & 4,729 & $2.1 \%$ \\
\hline 2007 & 895 & 18,489 & $4.8 \%$ & 49 & 1,352 & $3.6 \%$ & $169^{6}$ & 5,759 & $2.9 \%$ \\
\hline & 5,991 & 253,175 & $2.4 \%$ & 2,703 & 86,496 & $3.1 \%$ & 7,618 & 98,477 & $7.7 \%$ \\
\hline
\end{tabular}

${ }^{1}$ An unknown amount of oversize handling occurs during non-retention periods.

${ }^{2}$ Retention closed (and creel survey completed) in April for 1995 - 2000, and in June for 2004 and 2005.

${ }^{3}$ Retention closed (and creel survey completed) in March for 2007, in April for 2001 and 2006, in May for 1996 and 1997, and in June for 1995, 1998-2000 and 2003-2005.

${ }^{4}$ Retention closed (and creel survey completed) in May for 1996, and in June for 1995,2006, and 2007.

${ }^{5}$ Beginning in 2006, May - July spawning sanctuaries were implemented in The Dalles and John Day Reservoirs.

${ }^{6}$ Since no sampling was conducted in John Day Reservoir in January and February, that portion of this estimate is basaed on historical harvest averages. 
WHITE STURGEON MITIGATION AND RESTORATION IN THE COLUMBIA AND SNAKE RIVERS UPSTREAM FROM BONNEVILLE DAM

ANNUAL PROGRESS REPORT

APRIL 2007 - MARCH 2008

\section{REPORT C}

Developing, implementing, and evaluating a management plan for enhancing production of white sturgeon in reservoirs between Bonneville and McNary dams.

This report includes: The results of efforts to capture and mark white sturgeon in John Day Reservoir for population abundance estimates.

Prepared by:

Blaine L. Parker

Columbia River Inter-Tribal Fish Commission

729 NE Oregon Street, Suite 200

Portland, Oregon 97232, USA 


\section{TABLE OF CONTENTS}

\section{$\underline{\text { Page }}$}

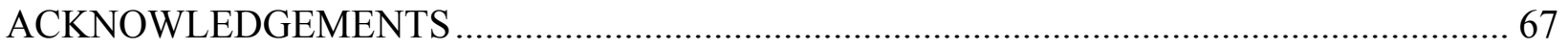

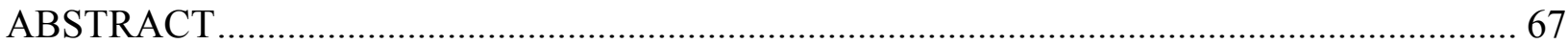

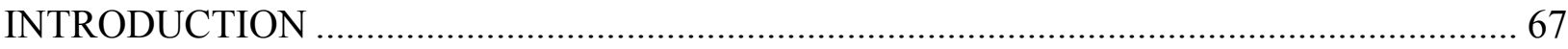

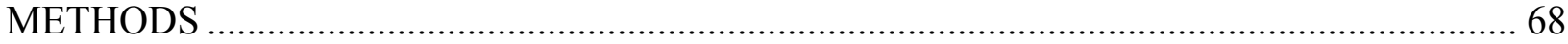

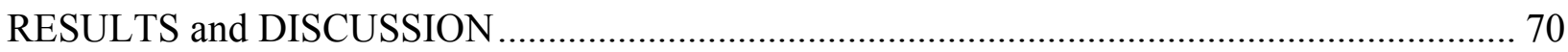

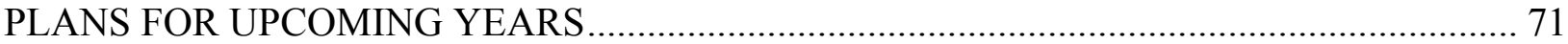

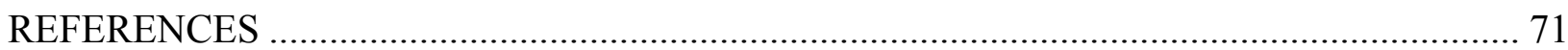

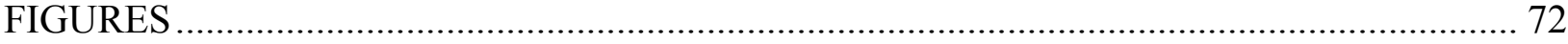




\title{
ACKNOWLEDGEMENTS
}

Our sincere appreciation and thanks to Yakama Nation fishery technicians Alvin McConnville, Chuck Gardee, and James Kiona; commercial fishermen Robert Brigham, Mathew McConville, Bryson Bronson and their crew members for their diligent efforts, particularly regarding the weeks of inclement weather conditions that occurred during the marking effort. Additional thanks goes out to ODFW staff for assistance with data processing and summarization for reporting requirements.

This report is dedicated to the memory of Charles (Chuck) Gardee Sr. who went to be with the Creator on January 31, 2008. His wit, humor, and knowledge of the Columbia River brightened many a day and brought many a smile and much laughter to those biologists and technicians who worked with him over the years.

\begin{abstract}
Columbia River Inter-Tribal Fish Commission's mark and tagging operations for the John Day Reservoir population survey began on December 4, 2006 and was completed on January 10, 2007. This field effort marked 4,236 white sturgeon with the $12^{\text {th }}$ left scute removal pattern and applied PIT tags to 2,485 of these fish. Tribal fishers set a total of 804 overnight gillnet sets during the 6 week sampling effort. No fish were caught in 394 sets, resulting in a mean catch of 10.7 fish for those nets that caught fish. A combined CRITFC, Washington Department of Fish and Wildlife, Oregon Department of Fish and Wildlife field crew performed the recapture effort in summer of 2007. Staff from ODFW will provide an update of the population estimate and structure in section A of this report.
\end{abstract}

\section{INTRODUCTION}

In this report, we summarize work completed by Columbia River Inter-Tribal Fish Commission (CRITFC), under subcontract with Oregon Department of Fish and Wildlife (ODFW), from 1 April 2007 through 31 March 2008 performed to meet objectives of Bonneville Power Administration (BPA) tasks outlined under project 198605000. Work elements were completed prior to the April 1, 2007 date, but are linked to the primary tasks for the April 1, 2007 through March 31, 2008 reporting period. The primary objectives for CRITFC under this project were to perform management activities that assisted ODFW and WDFW with respect to their management specific tasks of assessing population structure of white sturgeon and monitoring of the tribal commercial and nontribal sport fisheries. 
Our tasks for this period were to:

Task 1 Capture and mark/tag approximately 3,000 white sturgeon in John Day Reservoir for a population survey.

Task 2 Provide field assistance to cooperating agencies conducting population survey in John Day Reservoir during the summer sampling period.

Task 3 Provide assistance to cooperating agencies in conducting Age-0 surveys in selected Columbia River and Snake River reservoirs.

Task 4 Sample Zone 6 tribal commercial and subsistence fishery and work jointly with ODFW and Washington Department of Fish and Wildlife (WDFW) to estimate harvest and exploitation and characterize the commercial fishery for white sturgeon between Bonneville and McNary dam.

In addressing tasks 2, 3 and 4, WDFW will report the results of the harvest and exploitation rates (Task 4), and ODFW will report on the John Day reservoir population and YOY surveys (Tasks $2 \& 3$ ) in their respective sections of this report.

\section{METHODS}

\section{John Day Reservoir Population Survey}

\section{Capture, Mark and Pit Tagging}

Columbia River Inter-Tribal Fish Commission captured, marked, and tagged white sturgeon in John Day Reservoir in order to perform population monitoring. The capture, mark, and pit tag operation for John Day Reservoir began on December 4, 2006 and was completed on January $10^{\text {th }}, 2007$, for a total of six weekly fishing periods. Tribal fishers sampled John Day Reservoir from Rkm 355 to Rkm 468 (RM 222 to RM 281), divided into a series of $16.1 \mathrm{~km}$ sections, a total of seven sections in all, although the uppermost section was not sampled as project funds were expended prior to reaching the uppermost section (Figure C-1). Boat restricted zones and commercial fishing sanctuaries were not sampled during the marking effort. All crews began sampling in section one, near John Day Dam and moved upriver one section each week. We employed this strategy in an effort to mark fish throughout the entire reservoir and also to enhance fisher safety by keeping them relatively close to one another in case of mechanical problems or bad weather. A fishing week usually began on Monday and ran through Friday. Nets were checked and reset each day, with Monday being the first set day of the week and Friday being the last pull day of the week, except when limited by severe weather or mechanical problems. 
Three Yakama Nation (YN) fishery technicians and three tribal commercial fishermen with crew performed all sampling operations. Each contract fisher was required to provide three crewmembers to perform marking, measuring, and tagging of white sturgeon along with any other requested data collections. Columbia River InterTribal Fish Commission biologists and YN technicians were responsible for training fishers with measuring techniques, identifying marked fish, and tag application procedures. Fishery technicians recorded all data while fishers worked up the catch according to established protocol. At weeks end data was turned over to ODFW.

Fishing was performed from commercial fishing vessels with diver gill nets. Vessels consisted of two $8 \mathrm{~m}$ bow pickers and one $5.5 \mathrm{~m}$ open boats. The length of nets fished ranged from approximately 70 to $120 \mathrm{~m}$, and mesh size was either 20.3 or $25.4 \mathrm{~cm}$ stretched mesh. A variety of materials were used for anchors and floats. Fishers were paid a daily boat lease rate and a set fee for each captured and processed white sturgeon recorded on the data sheets. Because fishers were rewarded on a catch rate basis they were motivated to search out areas they felt would be productive fishing sites within the pre-described boundaries. Each fisher was typically able to run $10-15$ nets per day working daylight hours. The number of nets fished each day depended on catch rates and crew efficiency.

Captured white sturgeon were brought on board and removed from the gill net. All white sturgeon were examined for tags, tag scars, missing scutes, pectoral fin scars, and missing barbels. White sturgeon with missing scutes or tag scars were scanned with an Avid Power Tracker 8 microchip reader (Avid, Norco, CA) 1 and/or a Destron Fearing (Destron Fearing, St. Paul, MN) 1 passive integrated transponder (PIT) tag detector. All white sturgeon were measured to the nearest $\mathrm{cm} \mathrm{FL}$ and the $12^{\text {th }}$ left lateral scute was removed to indicate year of capture was 2006-2007. We did not weigh fish. In most cases, if the fork length was equal to or greater than $70 \mathrm{~cm} \mathrm{FL}$ and the fish did not possess a PIT tag (125 or $134 \mathrm{mghtz}$ ), a $134.2 \mathrm{MHz}$ ISO PIT tag was injected into the musculature beneath the armor posterior of the head, near the dorsal midline. Fish less than $70 \mathrm{~cm}$ were released after the year of capture scute mark was applied. The second left lateral scute was also removed in order to identify a PIT-tagged fish (Rein et al. 1994). We used a Biomark (BioMark, Boise, ID)1 MK5 general-purpose implanter with standard 12 gauge needles to inject PIT tags. All PIT tag numbers found upon examination or applied were recorded with biological information corresponding to the fish and later entered into a database maintained by ODFW. Upon the completion of the data collection process all fish were immediately released.

1 Use of trade names does not imply endorsement by CRITFC. 


\section{RESULTS and DISCUSSION}

\section{John Day Reservoir Capture, Mark and PIT Tagging}

\section{$\underline{\text { Effort and Catch }}$}

A total of 4,236 white sturgeon were captured in 804 gillnet sets, considerably more than the 2,848 sturgeon captured in 2003-2004 effort, with 1,408 sets (Parker and Kappenman 2005). Tagging efforts in 2000-2001 captured 3,019 sturgeon in 1,537 sets, while the 1996 effort only captured 1,212 fish for 804 sets. We marked all sturgeon with the $12^{\text {th }}$ left scute removal pattern described in the methods section. Of the 4,236 sturgeon captured, we applied pit tags to 2,485. White sturgeon captured ranged from 32 to $226 \mathrm{~cm}$ FL (Figure C-2), with a mean fork length of $86.0 \pm 0.20 \mathrm{~cm}$, the shortest documented mean fork length since we began participating in the stock assessment efforts. Previous tagging efforts mean fork lengths of $87.2 \mathrm{~cm}, 97 \mathrm{~cm}$, and $96 \mathrm{~cm}$ for the 2003-04, 200001, and 1996 tagging efforts, respectively (Parker 1997; Kappenman and Parker 2002; Parker and Kappenman 2005). The pronounced decline in mean fork length first documented in the 2003-04 sampling season was likely due to the recruitment of brood year 1996-98 sturgeons to the sampling gear.

Distribution of the catch based upon the total length size criteria used for sport and commercial fisheries; sublegal, legal, and oversize groups criteria consisted of $96 \%$ sub legal size (less than 43 inches FL or $109 \mathrm{~cm} \mathrm{FL),} \mathrm{3 \%} \mathrm{commercial/sport} \mathrm{legal} \mathrm{size}$ (between 43 inches and 54 inches FL or $109 \mathrm{~cm}$ and $137 \mathrm{FL} \mathrm{cm}$ ) and 1\% over legal size (greater than 54 inches FL or $137 \mathrm{~cm} \mathrm{FL).} \mathrm{The} \mathrm{total} \mathrm{mean} \mathrm{white} \mathrm{sturgeon} \mathrm{catch} \mathrm{per} \mathrm{set}$ for all sets combined was 5.44, more than the double the catch rate of 2.02 sturgeon per net documented in the previous sampling effort in 2003-2004 (Parker and Kappenman 2005). All white sturgeon captured and handled in John Day Reservoir were released back into the reservoir. Catch of non target species was varied, although the number tended to be low in numbers except for channel catfish Ictalurus punctatus (73), common carp Cyprinus carpio (29), largescale sucker Catostomus macrocheilus (9), walleye Sander vitreus (9), steelhead Oncorhynchus mykiss (6), northern pikeminnow Ptychocheilus oregonensis (5), and American shad Alosa sapidissima (2).

The 2006-07 tagging operation performed by CRITFC and ODFW is the fourth cooperative effort to determine population abundance and structure of white sturgeon in John Day Reservoir. We provide a summary of current CRITFC tagging effort, and ODFW reports the results of recapture efforts and abundance estimates. The information this cooperative effort yields will be used to update population estimates and structure, determine harvest quotas and determine the effect of ongoing mitigative activities on white sturgeon between Bonneville and John Day dams. 


\section{PLANS FOR UPCOMING YEAR}

Population surveys and estimates for The Dalles Reservoir, Age-0 sampling in selected Columbia River reservoirs and cooperative data collection on tribal commercial fisheries is scheduled for the coming year.

\section{REFERENCES}

Parker, B. L. 1997. Pages 152-167 in Rien, Thomas and Beiningen, Kirk, T.- Oregon Dept. of Fish and Wildlife, 1997. Effects of mitigative measures on productivity of white sturgeon in the Columbia River downstream from McNary Dam, and determine status and habitat requirements of white sturgeon populations in the Columbia and Snake rivers upstream from McNary Dam, 1995 Annual Report to Bonneville Power Administration, Portland, OR, Contract No. 1986B163584, Project No. 1986-050-00, 167 electronic pages (BPA Report DOE/BP-63584-11)

Kappenman, K. M., and B. L. Parker. 2002. Report D. Pages 114-129 in D.L. Ward, editor. White Sturgeon Mitigation and Restoration in the Columbia and Snake Rivers Upstream from Bonneville Dam. Annual Report to the Bonneville Power Administration, Portland, Oregon

Parker, B. L. and K. M. Kappenman. 2005. Report D. Pages 115-137 in Rien editor. White Sturgeon Mitigation and Restoration in the Columbia and Snake Rivers Upstream from Bonneville Dam. Annual Report to the Bonneville Power Administration, Portland, Oregon 


\section{FIGURES}

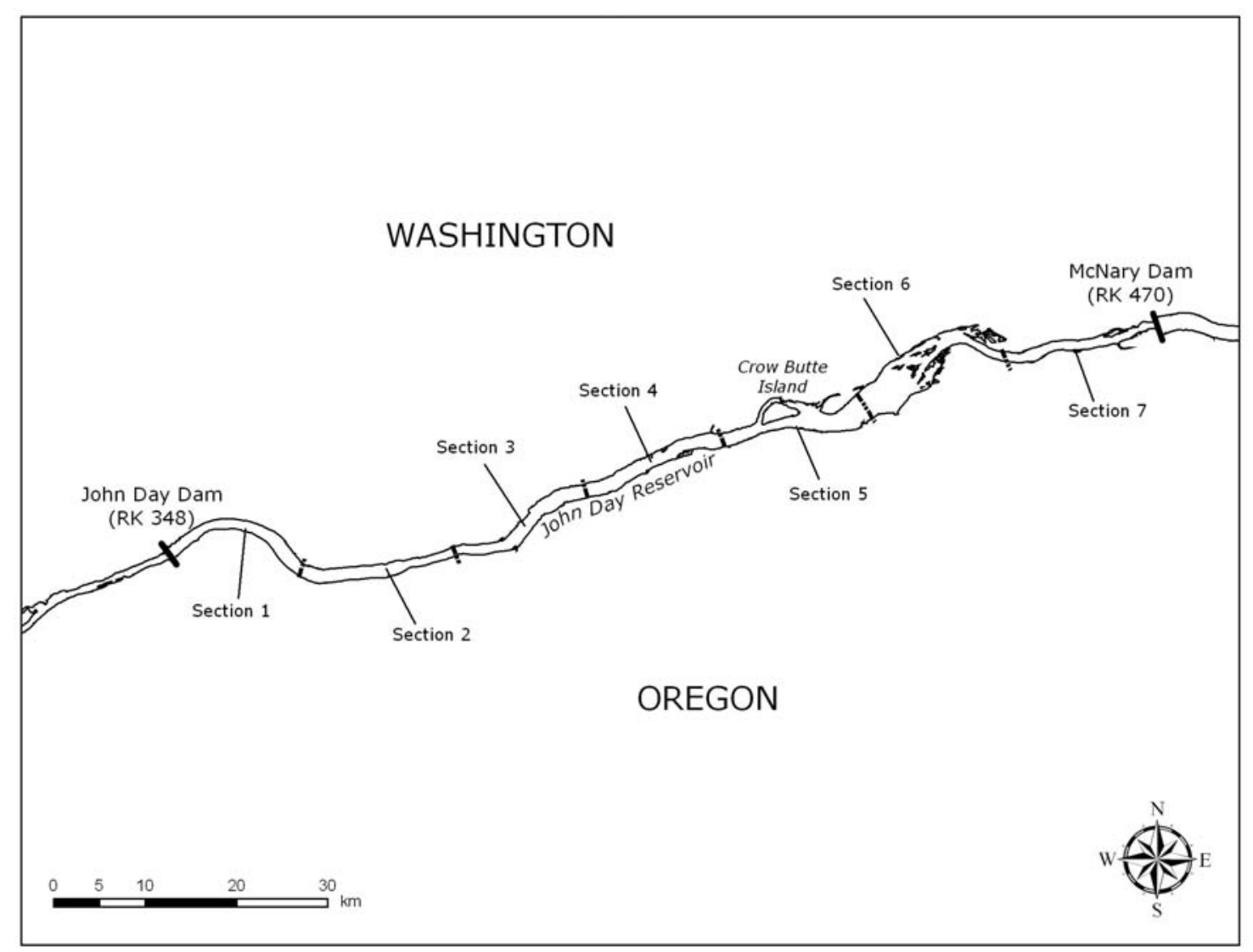

Figure C-1. Map of John Day Reservoir in the Columbia River where white sturgeon marking and tagging efforts were performed in 2006-07. Section 7 was not sampled due to budget restraints. 


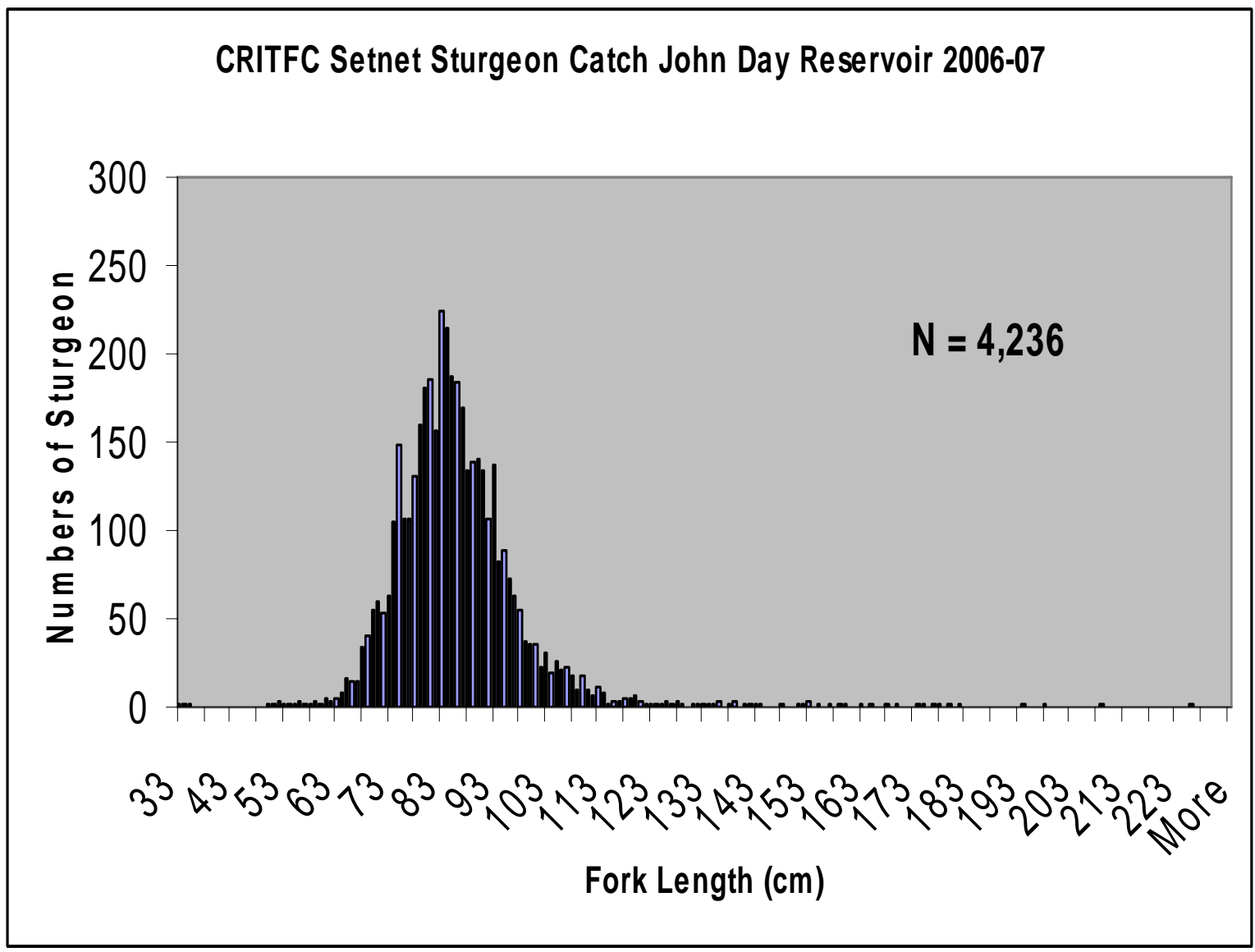

Figure C-2. Length frequency distribution $(10 \mathrm{~cm}$ increments $)$ for white sturgeon collected with setnets in John Day Reservoir in December 2006 and January 2007 by tribal fishers and Yakama Nation fish technicians. 


\title{
WHITE STURGEON MITIGATION AND RESTORATION IN THE COLUMBIA AND SNAKE RIVERS UPSTREAM FROM BONNEVILLE DAM
}

\author{
ANNUAL PROGRESS REPORT
}

APRIL 2007- MARCH 2008

\section{REPORT D}

\section{Determine spawning interval of white sturgeon in the Columbia River}

This report includes: Progress update on the maturation cycle in wild white sturgeon.

\author{
Prepared by: \\ Molly A.H. Webb \\ and \\ Kevin M. Kappenman \\ Montana Cooperative Fishery Research Unit \\ Montana State University \\ PO Box 173460 \\ Bozeman, MT 59717-3460
}




\section{TABLE OF CONTENTS}

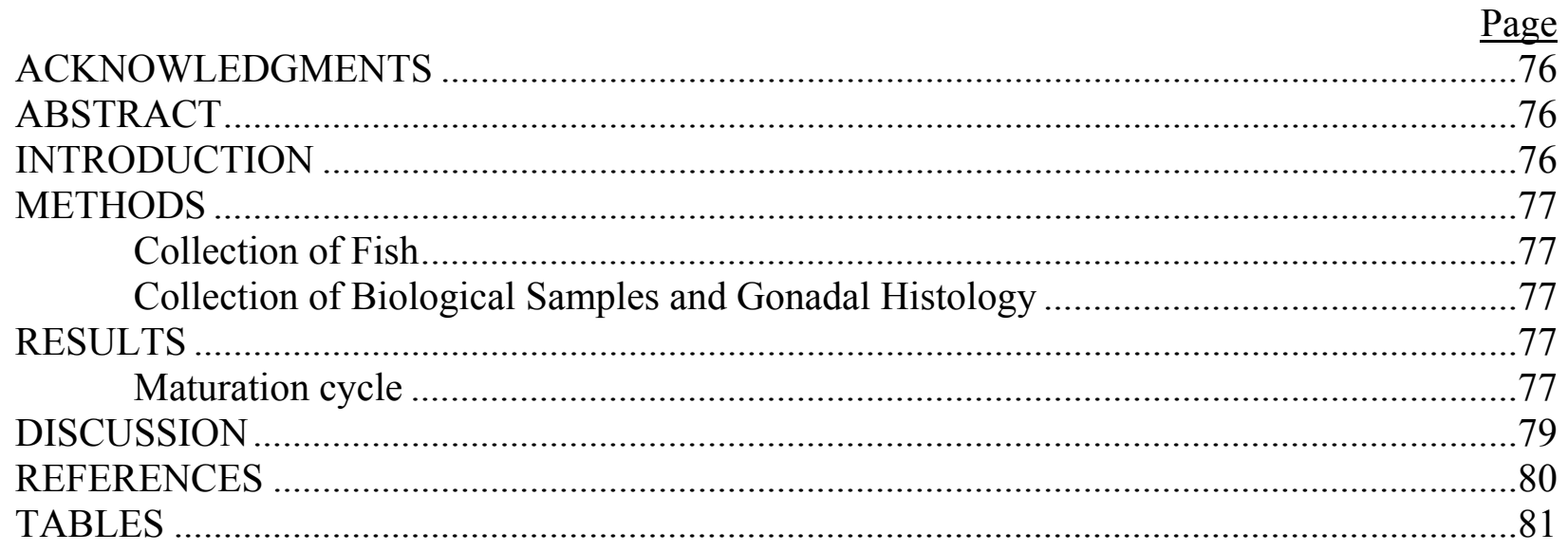




\title{
ACKNOWLEDGMENTS
}

We would like to thank Brad Cady and Brad James with Washington Department of Fish and Wildlife, volunteers for help with collecting samples from adult sturgeon below Bonneville Dam, and Eli Cureton and Trey Kucherka for processing gonadal tissue histologically. In-kind contribution for this work came from the U.S. Fish and Wildlife Service.

\begin{abstract}
During 1 April 2007 through 31 March 2008, Montana State University/U.S. Fish and Wildlife Service researchers collected gonadal biopsies from adult white sturgeon below Bonneville Dam with Washington Department of Fish and Wildlife. The objective of this research is to describe the maturation cycle in wild white sturgeon. White sturgeon were caught by set-lines. Gonadal tissue was collected by biopsy, and the gonad samples were processed histologically. A total of 660 adult white sturgeon have been marked with spaghetti tags, scute marks, and PIT tags below Bonneville Dam since $2000(n=183$ in 2000, $n=90$ in 2001, $n=67$ in 2002, $n=101$ in 2003, $n=57$ in 2004, $n=37$ in 2005, $n=67$ in 2006; $n=58$ ). In 2007, a total of 121 fish were caught, 50 of which were tagged in previous years and 58 of which were "new" fish to the study. Thirteen of the 121 fish handled were recaptured in the same season (2007). A total of 90 gonad samples were collected for histological analysis in 2007. Of the 90 gonad samples, 56 were collected from females and 32 were collected from males. The reproductive structure of the oversize white sturgeon population below Bonneville Dam was determined using the 20002007 data. Of the females $(n=375), 58 \%$ were pre-vitellogenic (Stages 1 and 2), 28\% were vitellogenic (Stages 3 and 4), 3\% were post-vitellogenic or ripe (Stage 5), 7\% were postovulatory (Stage 7), and 4\% were undergoing follicular atresia (Stage 8). Of the males $(n=196), 59 \%$ were non-reproductive (Stage 2), 16\% were mid-spermatogenic (Stage 3 and 4), 18\% were spermiating (Stage 5), and 7\% were post-spermiation (Stage 6). Using the shortest maturation cycle assigned, a 2-year maturation cycle was possible in $36 \%$ of the females, a 3 -year cycle was possible in $50 \%$ of the females, and a 4 -year cycle was possible in $14 \%$ of the females.
\end{abstract}

\section{INTRODUCTION}

This annual report describes progress of Montana State University (MSU) on the Bonneville Power Administration funded Project 198605000 - White Sturgeon Restoration and Enhancement in the Columbia and Snake Rivers Upstream from Bonneville Dam. This report covers the period of 1 April 2007 through 31 March 2008. 
During this reporting period, MSU worked on one task related to Objective 4 of the common objectives listed in the multi-agency project. Objective 4 involves assessment of losses to white sturgeon production due to development, operation, and configuration of the hydrosystem. Specifically, the task was to describe the maturation cycle for white sturgeon.

\section{METHODS}

\section{Collection of Fish}

Gonad samples were collected from sturgeon over the legal size limit $(>137-\mathrm{cm}$ fork length (FL), herein referred to as adult fish) below Bonneville Dam with the help of WDFW in June, July, and August 2007. Fish were captured using set-lines. Up to 10 individual set-lines with one hook each were baited with fresh or frozen shad and set for 1-2 hours. Each individual line was pulled and if a fish was not caught, the line was reset for another 1-2 hours. Set-lines were not left in the water overnight. Individual fish were marked with spaghetti tags, scute marks, and passive integrative transponder (PIT) tags as described in Rien et al. (1994). Fork length and total length (TL) were measured for every fish.

\section{Collection of Biological Samples and Gonadal Histology}

Gonadal tissue was collected following the protocol of Webb (1999) and stored in phosphate-buffered formalin. Gonadal tissue was embedded in paraffin, sectioned at $5 \mu \mathrm{m}$, and stained by Periodic Acid Schiff reagent (Luna 1968). Slides were examined under a compound scope (Leica, 40x-1000x), and the germ cells were scored for stage of maturation according to the modified protocol of Van Eenennaam and Doroshov (1998) for white sturgeon (Table D-1). When assigning the spawning periodicity in recaptured females, it was assumed that the fastest cycle in a pre-vitellogenic Stage 2 female with no evidence of a chorion in the oocytes was likely 3 years given information on the time required for differentiation of follicular membranes in cultured white sturgeon reared under optimal conditions.

\section{RESULTS}

\section{Maturation cycle}

A total of 660 adult white sturgeon have been marked with spaghetti tags, scute marks, and PIT tags below Bonneville Dam ( $\mathrm{n}=183$ in $2000, \mathrm{n}=90$ in $2001, \mathrm{n}=67$ in $2002, \mathrm{n}=101$ in 2003, $n=57$ in 2004, $n=37$ in 2005, $n=67$ in 2006; $n=58$ in 2007). In 2007, a total of 121 fish were handled, 50 of which were tagged in previous years, 58 of which were "new" fish to the study, and 13 of which were handled twice in the season (within season recapture). 
A total of 90 gonad samples were collected for histological analysis from white sturgeon below Bonneville Dam. Of the 90 gonad samples, 56 were collected from females, 32 were collected from males. Two of the samples did not contain germ cells, but all of these fish were identified as males with small testicular lobes in the field. It is often very difficult to collect gonadal tissue from males with small testicular lobes. Histological analysis revealed 34 Stage 2 (pre-vitellogenic), seven Stage 3 (early vitellogenic), ten Stage 4 (mid-vitellogenic), zero Stage 5 (post-vitellogenic or ripe), and five Stage 7 (post-ovulatory) females. Three females had significant numbers of atretic bodies indicating that follicular atresia may have occurred within the last 2-9 months. These two females were classified as Stage 2 (pre-vitellogenic) as this was the primary stage of development seen in the gonadal sample. Histological analysis revealed 21 Stage 2 (pre-meiotic), six Stage 3 and 4 (mid-spermatogenic), one Stage 5 (spermiating), and four Stage 6 (post-spermiating) males.

No post-vitellogenic or ripe females were captured in 2007. However, a high number of post-ovulatory females $(n=5)$ were captured in 2007 . The post-ovulatory females were captured between 3 July and 19 July at water temperatures of $18-21^{\circ} \mathrm{C}$. The rate of gonadal recrudescence ("gonad clean-up") and the influence of water temperature on this process are unknown in white sturgeon. The spermiating male was captured on 12 July when water temperature was $20^{\circ} \mathrm{C}$, and the post-spermiating males were captured on 6 July and 20 July.

In 2007,50 previously marked fish were recaptured $(46.3 \%$ of the total fish captured in 2007). The PIT tag was lost in one female, therefore this individual could not be retraced to the year it was tagged (2000). A new PIT tag was applied to this female. Two fish are not included in this report as the fish cannot yet be found in the database. Of the 47 fish that could be tracked back to their original year of tagging, 24 were females, 21 were males and two were hermaphrodites (Table D-2). Four of the females were originally tagged in 2000, three were originally tagged in 2002, four were originally tagged in 2003, two were originally tagged in 2004, two were originally tagged in 2005, and nine were originally tagged in 2006 . Five of the males were originally tagged in 2000 , two were tagged in 2001 , three were tagged in 2002, one was tagged in 2003, four were tagged in 2004, one was tagged in 2005, and five were tagged in 2006. The maturation cycle could not be determined in ten fish (seven males, two females, and one intersex fish) due to the fish not being biopsied, the absence of germ cells in the gonad sample at the time of tagging or recapture, or the lack of blood plasma for steroid analysis. The fastest physiologically possible maturation cycle was assigned to each fish. Using the shortest maturation cycle assigned, a 2-year cycle was possible in $36 \%$ of the females, a 3-year cycle was possible in $50 \%$ of the females, and a 4-year cycle was possible in $14 \%$ of the females. All males had a maturation cycle of 2 years $(86 \%)$ or longer $(14 \%)$. Two fish had evidence of postovulatory follicles one year after spawning indicating that gonadal recrudescence was not complete within a year as previously suspected in white sturgeon. The two intersex fish had predominately testicular tissue with oocytes interspersed.

The reproductive structure of the adult white sturgeon population below Bonneville Dam was determined using the 2000-2007 data. Because it is difficult to collect gonadal tissue from males with small testicular lobes, reproductive structure of the adult male population below Bonneville Dam is calculated using a smaller sample size compared to females. Hence, the sex ratio of the adult population is not available using the gonadal tissue collected for histological 
analysis of stage of maturity. Of the females $(n=375), 58 \%$ were pre-vitellogenic (Stages 1 and 2), 28\% were vitellogenic (Stages 3 and 4), 3\% were post-vitellogenic or ripe (Stage 5), 7\% were postovulatory (Stage 7), and 4\% were undergoing follicular atresia (Stage 8). Of the males $(\mathrm{n}=196), 59 \%$ were non-reproductive (Stage 2), 16\% were mid-spermatogenic (Stage 3 and 4), $18 \%$ were spermiating (Stage 5 ), and $7 \%$ were post-spermiation (Stage 6).

\section{DISCUSSION}

Of the adult females sampled in 2000-2007, 58\% were pre-vitellogenic (Stages 1 and 2), $28 \%$ were vitellogenic (Stages 3 and 4), 3\% were post-vitellogenic or ripe (Stage 5), 7\% were postovulatory (Stage 7), and 4\% were undergoing follicular atresia (Stage 8). Welch and Beamesderfer (1995) found 37\% of the females $>166 \mathrm{~cm}$ FL in Bonneville, The Dalles, and John Day Reservoirs were maturing (equivalent to Stages 3 and 4 in this study), while 10\% of the females were mature or spent (equivalent to Stages 5 and 7 in this study), similar to this study. DeVore et al. (1995) found $2 \%$ of the females $\geq 110 \mathrm{~cm}$ FL below Bonneville Dam were ripe or spent (equivalent to Stages 5 and 7 in this study), which is lower than the percent in this study and may be an effect of inclusion of fish $\geq 110 \mathrm{~cm}$ FL. While $10 \%$ of the adult females in this study were capable of or had spawned successfully, $25 \%$ of the adult males were capable of or had spawned successfully, which is identical to the values reported in 2006.

Five post-ovulatory females were captured in 2007. Though this is a smaller number of females compared to 2006, this is still a larger number of post-ovulatory females compared to 2000-2005. It is not possible to determine whether this is due to a good water year providing proper spawning cues and habitat, decreased stress associated with the change in fishing regulations, or random chance. It will be possible to compile spill information from Bonneville Dam and compare conditions (temperature and flow) and spawning habitat over the course of this study for a future report. Fishing regulation for adult white sturgeon changed in 2004. Given that the reproductive cycle of female white sturgeon requires a minimum of 2 years, it would seem that if a positive effect of more protective regulations was to occur it would be seen two or more years following the regulation change.

Sustainable harvest levels of sturgeon in the Columbia River are based on population models and fecundity estimates (DeVore et al. 1995), of which spawning frequency and an understanding of the maturation cycle are critical elements. Exact knowledge of the maturation cycle in white sturgeon in the Columbia River requires following the stage of development in individual fish over many years. Females in all stages of development were found throughout the winter and spring below Bonneville Dam which is consistent with a maturation cycle longer than one year, as previously discussed for white sturgeon by DeVore et al. (1995) and Doroshov et al. (1997). The data collected from recaptured adult fish below Bonneville Dam in 2000-2007 revealed that males of reproductive size are not spawning every year unlike in culture. Using the shortest maturation cycle assigned, a 2-year maturation cycle was possible in $36 \%$ of the females, a 3 -year cycle was possible in $50 \%$ of the females, and a 4 -year cycle was possible in $14 \%$ of the females. This information is critical to management of Columbia, Snake, and 
Kootenai River white sturgeon populations. The maximum fraction of mature wild white sturgeon in the Columbia River is estimated to be $33 \%$ based on a 3-year cycle (Welch and Beamesderfer 1995). Given that the preliminary results of this study show a 2 to $5+$ year cycle in the majority of females and that $10 \%$ of the adult females in this study were capable of or had spawned successfully, it appears that the estimated maximum fraction of spawning females may be $10-33 \%$.

\section{REFERENCES}

DeVore, J. D., B. W. James, C. A. Tracy, and D. A. Hale. 1995. Dynamics and potential production of white sturgeon in the unimpounded lower Columbia river. Transactions of the American Fisheries Society 124:845-856.

Doroshov, S. I., G. P. Moberg, and J. P. Van Eenennaam. 1997. Observations on the reproductive cycle of cultured white sturgeon, Acipenser transmontanus. Environmental Biology of Fishes 48: 265-278.

Luna, L. G. 1968. Manual of Histological Staining Methods of the Armed Forces Institute of Pathology. McGraw-Hill Book Company, New York.

Rien, T. A., R. C. P. Beamesderfer, and C. A. Foster. 1994. Retention, recognition, and effects on survival of several tags and marks for white sturgeon. California Fish and Game 80(4):161-170.

Van Eenennaam, J. P. and S. I. Doroshov. 1998. Effects of age and body size on gonadal development of Atlantic sturgeon. Journal of Fish Biology 53:624-637.

Webb, M. A. H. 1999. Ovarian steroidogenesis and environmental temperature effects during final ovarian maturation and ovulation of white sturgeon (Acipenser transmontanus Richardson). Dissertation, University of California, Davis.

Welch, D. W., and R. C. Beamesderfer. 1995. Report F. Pages 89-107. in R. C. Beamesderfer and A. A. Nigro, editors. Status and habitat requirements of the white sturgeon populations in the Columbia River downstream from McNary Dam. Final Report to the Bonneville Power Administration, Portland, Oregon. 


\section{TABLES}

Table D-1. Stages of gonadal development identified from gonadal biopsies of white sturgeon.

\begin{tabular}{|c|c|c|}
\hline & $\begin{array}{c}\text { Developmental } \\
\text { Stage }\end{array}$ & Description \\
\hline \multicolumn{3}{|l|}{ Females } \\
\hline Differentiation & 1 & Clusters of oogonia \\
\hline Previtellogenic & 2 & $\begin{array}{l}\text { Endogenous growth of oocyte, small translucent } \\
\text { oocytes }<0.6 \mathrm{~mm}\end{array}$ \\
\hline Early vitellogenic & 3 & $\begin{array}{l}\text { Enlarged oocytes with thin vitelline envelope } \\
\text { surrounded by granulosa cell layer and yolk } \\
\text { globules, cream to grey colored } 0.6-2.1 \mathrm{~mm}\end{array}$ \\
\hline Mid-vitellogenic & 4 & $\begin{array}{l}\text { Fully differentiated follicular layer and yolk } \\
\text { platelets, pigmented ovarian follicles } 2.2-2.9 \mathrm{~mm}\end{array}$ \\
\hline Post-vitellogenic & 5 & $\begin{array}{l}\text { Fully grown ovarian follicles with differentiated } \\
\text { chorion and germinal vesicle displaced to animal } \\
\text { pole, fully pigmented ovarian follicles }>3.0 \mathrm{~mm}\end{array}$ \\
\hline Oocyte maturation & 6 & $\begin{array}{l}\text { Ovulated oocytes that have undergone germinal } \\
\text { vesicle breakdown }\end{array}$ \\
\hline Post-ovulatory & 7 & $\begin{array}{l}\text { Ovaries contain numerous postovulatory follicles } \\
\text { and the next generation of oocytes similar to } \\
\text { Stage } 2\end{array}$ \\
\hline Atretic & 8 & $\begin{array}{l}\text { Atretic vitellogenic follicles containing residual } \\
\text { yolk, atretic mature follicles containing residual } \\
\text { yolk and dark pigment, presence of atretic bodies }\end{array}$ \\
\hline \multicolumn{3}{|l|}{ Males } \\
\hline Differentiation & 1 & Clusters of primary spermatogonia \\
\hline Pre-Meiotic & 2 & Spermatogonia undergoing mitosis \\
\hline Onset of Meiosis & 3 & Spermatogonia $(\sim 50 \%)$ and spermatocytes \\
\hline Meiotic & 4 & $\begin{array}{l}\text { Majority of cysts contain spermatocytes and } \\
\text { spermatids, less than } 25 \% \text { of cysts contain } \\
\text { spermatogonia }\end{array}$ \\
\hline Spermiation & 5 & Cysts and ducts contain spermatozoa \\
\hline Post-spermiation & 6 & Residual spermatozoa in testicular lobules \\
\hline
\end{tabular}


Table D-2. Oversize white sturgeon recaptured in 2007 below Bonneville Dam. Fish identification is the last seven digits of the PIT tag number. Sex and stage of maturity is based on histological evaluation except when gonadal tissue was not collected or the tissue sample had no germ cells present. In these cases, sex and stage of maturity was determined by sex steroid concentrations when available (these fish are denoted by *). Several fish have been captured three or four times, and all data is presented in chronological order. The fastest maturation cycle physiologically possible is assigned and + signs denote uncertainty associated with continued progression of the maturation cycle in out-years. $U=$ unknown due to no gonadal biopsy, no germ cells present in histological sample, and no plasma sex steroid data available. NA = spawning periodicity information not available given samples.

\begin{tabular}{|c|c|c|c|c|c|c|}
\hline Fish ID & $\begin{array}{c}\text { Year } \\
\text { Tagged }\end{array}$ & Years Recaptured & $\begin{array}{c}\text { Fork Length } \\
(\mathrm{cm}) \\
\text { (yr tagged / 2007) }\end{array}$ & Sex & $\begin{array}{l}\text { Stage of Maturity } \\
\text { (yr tagged / 2007) }\end{array}$ & $\begin{array}{l}\text { Spawning } \\
\text { Periodicity }\end{array}$ \\
\hline 07560845 & 2000 & 2007 & $207 / 237$ & Female & Stage $2 * /$ Stage 3 & $2-8+$ years \\
\hline 07528697 & 2000 & 2007 & $200 / 211$ & Female & U/Stage 2 & NA \\
\hline 07526255 & 2000 & 2006, 2007 & $231 / 235 / 237$ & Female & U/Stage $2 /$ Stage 2 & $3+$ years \\
\hline 08372533 & 2002 & 2007 & $211 / 215$ & Female & Stage $4 /$ Stage 3 & $3+$ years \\
\hline 08343098 & 2002 & 2007 & $240 / 245$ & Female & Stage $2 *$ Stage 3 & $4+$ years \\
\hline 08379733 & 2002 & 2004,2007 & $238 / 239 / 242$ & Female & Stage $4 /$ Stage $4 /$ Stage 4 & $2-3$ years \\
\hline 08356117 & 2003 & 2007 & $220 / 226$ & Female & Stage $5 /$ Stage 2 & 3 year \\
\hline 08352202 & 2003 & 2007 & $251 / 252$ & Female & Stage $2 /$ Stage 2 & $3-4+$ years \\
\hline 10509696 & 2004 & 2007 & $235 / 234$ & Female & Stage $2 /$ Stage 4 & 2-3 years \\
\hline
\end{tabular}




\begin{tabular}{|c|c|c|c|c|c|c|}
\hline 11297250 & 2004 & 2006,2007 & $217 / 218 / 218$ & Female & Stage $7 /$ Stage $7 /$ Stage $2+7^{3}$ & $2-3$ years \\
\hline 19345521 & 2005 & 2007 & $193 / 197$ & Female & Stage $2 /$ Stage 2 & $4+$ years \\
\hline 19702411 & 2005 & 2006,2007 & $240 / 236 / 238$ & Female & Stage $2 /$ Stage $2 /$ Stage 2 & $4+$ years \\
\hline 19682308 & 2006 & 2007 & $229 / 230$ & Female & Stage $2 / U$ & NA \\
\hline 19473094 & 2006 & 2007 & $197 / 201$ & Female & Stage $2 /$ Stage 2 & $3+$ years \\
\hline 19366046 & 2006 & 2007 & $231 / 235$ & Female & Stage $7 /$ Stage 3 & $2+$ years \\
\hline 19401639 & 2006 & 2007 & $220 / 217$ & Female & Stage $3 /$ Stage 7 & $2+$ years \\
\hline 19352284 & 2006 & 2007 & $153 / 158$ & Female & Stage $2 /$ Stage 2 & $3+$ years \\
\hline 19461385 & 2006 & 2007 & $228 / 226$ & Female & Stage $4 /$ Stage 7 & $2+$ years \\
\hline 06842393 & 2000 & 2007 & $213 / 222$ & Male & Stage $2 * /$ Stage 4 & $2+$ years \\
\hline 06897179 & 2000 & 2001,2007 & $191 / 198 / 195$ & Male & Stage $2 /$ Stage $2 /$ Stage 2 & $2+$ years \\
\hline 06913623 & 2000 & 2005,2007 & $191 / 196 / 196$ & Male & Stage $2 * /$ Stage $2 /$ Stage 2 & $2+$ years \\
\hline
\end{tabular}




\begin{tabular}{|c|c|c|c|c|c|c|}
\hline 07562081 & 2000 & 2005,2007 & $193 / 192 / 191$ & Male & U/Stage 2, Stage 2 & $2+$ years \\
\hline 08373136 & 2001 & 2007 & $257 / 254$ & Male & Stage $2 /$ Stage 2 & $2+$ years \\
\hline 08354293 & 2002 & 2007 & $209 / 213$ & Male & Stage $2 / \mathrm{U}$ & NA \\
\hline 08354945 & 2002 & 2007 & $213 / 216$ & Male & Stage $2 / \mathrm{U}$ & NA \\
\hline 08344221 & 2003 & 2004,2007 & 190/192/192 & Male & Stage $2 /$ Stage $2 /$ Stage 2 & $2+$ years \\
\hline 11291146 & 2004 & 2007 & $225 / 221$ & Male & Stage $2 * / U$ & NA \\
\hline 11295541 & 2004 & 2006,2007 & $198 / 200 / 199$ & Male & Stage $4 /$ Stage $3 / U$ & $2+$ years \\
\hline 19367764 & 2005 & 2006,2007 & $170 / 173 / 172$ & Male & U/Stage $2 /$ Stage 2 & $3+$ years \\
\hline 19408360 & 2006 & 2007 & $224 / 221$ & Male & Stage $2 / U$ & NA \\
\hline 19473071 & 2006 & 2007 & $218 / 215$ & Male & Stage $5 / \mathrm{U}$ & NA \\
\hline 19438659 & 2006 & 2007 & $160 / 160$ & Male & Stage $2 /$ Stage 2 & $3+$ years \\
\hline 19688748 & 2006 & 2007 & $145 / 149$ & Male & U/Stage 2 & NA \\
\hline
\end{tabular}




\begin{tabular}{|c|c|c|c|c|c|c|}
\hline 07575675 & 2000 & $2002,2006,2007$ & $219 / 223 / 219 / 218$ & Intersex $^{1}$ & U/Stage $2 /$ Stage $2 /$ Stage 2 & $3+$ years \\
\hline 19381752 & 2006 & 2007 & $236 / 236$ & Intersex & Stage $2 / \mathrm{U}$ & NA \\
\hline \multicolumn{7}{|c|}{$\begin{array}{l}{ }^{1} \text { In } 2000 \text {, no germ cells present. In } 2002 \text {, predominately testicular tissue with oocytes visible microscopically and interspersed. In } \\
2006 \text {, predominately testicular tissue with oocytes visible macroscopically and interspersed. In 2007, only testicular tissue visible } \\
\text { macroscopically and microscopically. } \\
{ }^{2} \text { Stage } 2 \text { in } 2007 \text { with atretic bodies seen throughout the tissue indicating atresia of vitellogenic follicles in } 2006 \text {. } \\
{ }^{3} \text { Post-ovulatory follicles in } 2006 \text { were open indicating spawning in } 2006 \text {, while post-ovulatory follicles were small and collapsed in } \\
2007 \text { indicating that gonadal recrudescence was not complete by } 2007 \text {. } \\
{ }^{4} \text { Collapsed post-ovulatory follicles present in both } 2006 \text { and } 2007 \text {. Predominant maturational stage was Stage } 2 \text { in both years } \\
\text { indicating that spawning most likely occurred in } 2006 \text { and gonadal recrudescence was not complete by } 2007 \text {. }\end{array}$} \\
\hline
\end{tabular}

